

IUSFILOSOFÍA CON VENTANAS 

Juan Guillermo Durán Mantilla

\title{
IUSFILOSOFÍA CON VENTANAS
}

\author{
UNA FILOSOFÍA JURÍDICA MIRADA \\ DESDE EL PUNTO MEDIO ARISTOTÉLICO
}


Durán Mantilla, Juan Guillermo, 1957-

Iusfilosofía con ventanas : una filosofía jurídica mirada desde el punto medio aristotélico / Juan Guillermo Durán Mantilla. -- Bogotá : Grupo Editorial Ibáñez, 2016.

160 páginas ; $24 \mathrm{~cm}$.

Incluye bibliografía.

ISBN 978-958-749-620-8

1. Aristóteles, 384-322 a. de C - Pensamiento jurídico. 2. Filosofía del derecho 3. Ética legal 4. Justicia I. Tít.

$340.1 \mathrm{~cd} 21$ ed.

A1537748

CEP-Banco de la República-Biblioteca Luis Ángel Arango

(C) Juan Guillermo Durán Mantilla

(C) Universidad Santo Tomas

Carrera 9 No. $72-90$

Facultad de Derecho

Bogotá - Colombia
(C) Grupo Editorial IbáÑEZ Carrera 69 Bis № 36-20 Sur Teléfonos: 2300731 - 2386035 Librería: Calle 12B № 7-12 L.1 Tels.: 2835194 - 2847524 Bogotá, D.C. - Colombia www.grupoeditorialibanez.com

ISBN: 978-958-749-620-8

Diseño de carátula: Kevin Nuñez

Diagramación electrónica: Deissy Alejandra Rodríguez

Queda prohibida la reproducción parcial o total de este libro por cualquier proceso reprográfico o fónico, especialmente por fotocopia, microfilme, offset o mimeógrafo.

Ley 23 de 1982

(B) 2016 


\section{COMITÉ CIENTÍFICO}

Roch Charles Little

Doctor de la Universidad de Laval, Canadá. Profesor

e investigador de la Universidad Nacional

Bernd Marquard

Doctor en Derecho Universidad St. Gallen, Suiza. Profesor e investigador de la Universidad Nacional.

\section{COMITÉ EDITORIAL}

Félix Raúl Martínez Cleves

Doctor en Historia Universidad Nacional. Profesor e investigador de la Universidad del Tolima

Manuel Horacio Vásquez

Doctor en Historia Universidad de Nantes, Francia.

Profesor e investigador de la Universidad del Tolima.

\section{PARES ACADÉMICOS}

Diego Mauricio Higuera Jiménez

Doctor en Derecho

Universidad Externado de Colombia

Docente UPTC de Colombia

Norhys Esther Torregroza Jiménez

Doctora en Derecho

Universidad Externado de Colombia

Docente Universidad Libre 

Dedico este libro de reflexión a grandes espíritus de todos los tiempos que viven aún:

Aristóteles, maestro de la virtud, entendida como punto medio entre extremos;

Martin Luther King y Mahatma Gandhi, quienes enseñaron a liberar a los hombres oprimidos de su entorno logrando así avanzar en la justicia;

Federico Ozanam, quien enseñó que su vida tenía sentido siendo servidor de los pobres;

Albert Einstein quien dijo que el hombre sólo es grande estando de rodillas.

$$
* * *
$$

Y especialmente lo dedico a mis alumnos de Filosofia del Derecho, para quienes de manera particular van estas líneas de iniciación a ella. 



\section{CONTENIDO}

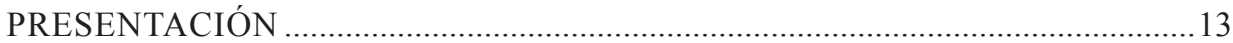

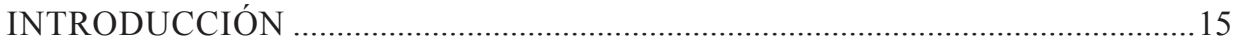

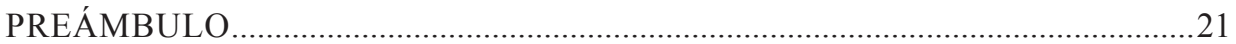

I. SENTIDO O LOGOS

DE LA IUSFILOSOFÍA

A. SENTIDO DIFÍCIL, PERO SIEMPRE VALIOSO,

DE LA FILOSOFÍA Y DE LA FILOSOFÍA DEL DERECHO

B. SENTIDO E IMPORTANCIA DE LA FILOSOFÍA

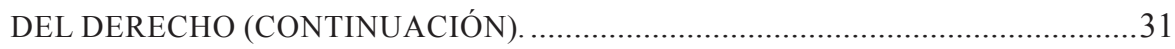

C. SENTIDO DE FONDO DE LA IUSFILOSOFÍA (CONTINUACIÓN).......................35

D. UNA DIGRESIÓN NECESARIA EN MATERIA

DE SENTIDO: TECNOLOGÍA Y FILOSOFÍA .................................................... 36

E. TOLERANCIA Y DIÁLOGO:

CONDICIONES PARA FILOSOFAR EN DERECHO

\section{HISTORIA DE LA IUSFILOSOFÍA}

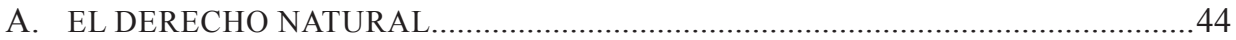

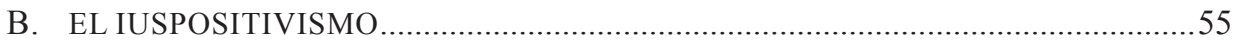

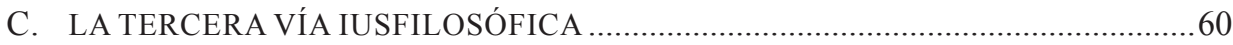

III. REFERENTES MATERIALES DEL DERECHO

DEDUCIDOS DE LA ANTERIOR HISTORIA.

VENTANAS DEL DERECHO

A. LA PERSONA HUMANA 
A.1. UNA POSICIÓN IUSFILOSÓFICA ACTUAL - QUE VA CONTRA CORRIENTE Y POR ESO ES IUSFILOSÓFICA-, Y DE PETICIÓN DE MORALIDAD EN EL DEBATE PÚBLICO -NO DE MORALISMO-. 76

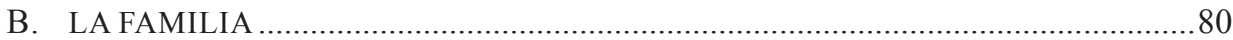

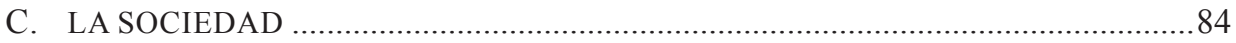

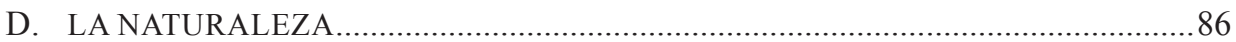

E. EL ESTADO …........................................................................................ 90

F. CONCLUSIONES AL TEMA

DE LOS REFERENTES MATERIALES DEL DERECHO .....................................98

\section{LA JUSTICIA COMO FIN DEL DERECHO}

A. ALGUNAS NOCIONES DE JUSTICIA ............................................................ 101

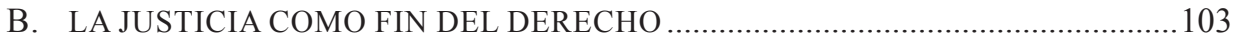

C. HERRAMIENTAS GENERALES

PARA ALCANZAR, PARCIALMENTE, LA JUSTICIA........................................ 105

D. LA HERRAMIENTA CONCRETA DE LOS DERECHOS HUMANOS ...................107

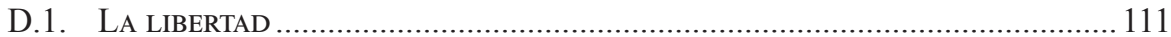

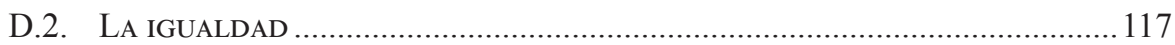

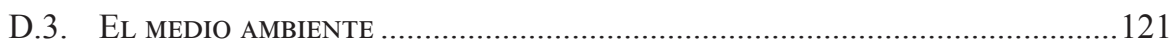

D.4. AlgunOS APORTES PARA UNA IUSFILOSOFÍA SOCIAL................................... 125

E. LA HERRAMIENTA CONCRETA DE LA POLÍTICA. OTRA VENTANA..............133

F. LA HERRAMIENTA CONCRETA DE LA ECONOMÍA. UNA VENTANA MÁS. ..138

$$
\text { V. Y ... ¿QUÉ ES EL DERECHO? }
$$

Y... ¿QUÉ ES EL DERECHO?. 


\section{PRESENTACIÓN}

El cuidadoso trabajo investigativo ${ }^{1}$ y pedagógico del Dr. Durán Mantilla inicia proponiendo un mapa de la filosofía del derecho útil para reflexionar de fondo sobre su sentido y fin último, resultando clave la intención crítica que anima este libro, particularmente respecto a la tendencia cuantitativista de corte tecno-científico que parece dominar el horizonte epistemológico actual.

Rodeados de una lógica productivista del conocimiento encarnada en modelos de medición como el que actualmente campea en instituciones estatales como Colciencias, el libro de Durán Mantilla constituye un soplo de aire fresco frente al encierro algorítmico de esta lógica operativa. En la primera parte de su obra sostiene el autor "la tendencia de hoy -aunque de hace ya algún tiempo considerable-, es la exaltación de la ciencia exacta, del número, del conteo, de la estadística", con lo que se verifica este estandarizado estado de cosas y se plantea una oposición dialéctica y ponderada desde meditaciones ontológicas. Estamos en presencia así de una consideración crítica sobre las condiciones del pensamiento jurídico en general.

En este sentido, en un particularmente lúcido e incisivo apartado del libro, y encarando la inercia tecno-fílica que parece reducir a las personas a consumidores pasivos pero extáticos de los dispositivos tecnológicos, las reflexiones del autor cortocircuitan esta fascinación y amplían el horizonte sensible más allá de la absorción inconsecuente en el continuo de pantallas que nos asfixian.

Por otra parte la caracterización de un ideal de justicia desde autores canónicos de la reflexión ius-filosófica conlleva una entusiasta toma de partido por la tercera vía, siempre contextualizando la reflexión en sus coordenadas históricas pertinentes. Desde Aristóteles la genealogía de conceptos cardinales de la tradición jurídica emprendida, revela posibilidades críticas insospechadas en autores clásicos y contemporáneos.

1 Correspondiente al proyecto de investigación en filosofía del derecho que el Dr. Durán tiene inscrito y en desarrollo en el Centro de Investigación "Francisco de Vitoria" de la Facultad de Derecho de la Universidad Santo Tomás. 
Se percibe un nervio crítico considerable cuando la distinción teoría-praxis, que pareciera darse por obvia en nuestras facultades de derecho, es puesta en perspectiva de los ideales y principios normativos, que incluso desde el preámbulo de la constitución, configura una imagen del derecho capaz de oponerse a la inercia de poderes económicos establecidos, desconocedores de estas premisas.

Un punto particular, resaltado al hablar de "Sentido o logos de la iusfilosofia" es el referente a la absorción sensorial que nos asedia "cuando asistimos a una época de lo visible, que sólo cree en lo que ve con los ojos corporales, de la imagen tecnológica", haciéndose muy pertinente este discurso en la desidealización del hedonismo apantallante al que nos referíamos más arriba.

En suma, se trata de una obra que rinde honor a su título, donde por las ventanas que abre el autor, se cuela una luz de esperanza ante el oscurantismo tecno-racionalista y mercadotécnico como criterio único de validez del conocimiento jurídico, siempre contextualizando la emergencia de los diferentes estilos de pensamiento ius-filosófico, pero sin olvidar la misión de orientación que debe informar la reflexión de los abogados.

Esperamos que más allá de las ventanas (Windows) de un sistema operativo devenido hegemónico, estas otras ventanas como líneas de fuga, posibiliten una comprensión informada de la fundamentación del derecho en sentido amplio, y catapulten a los estudiantes a formas de sensibilidad menos mediadas por la operativización automática e irreflexiva del saber, y más en el atisbo de un orden jurídico desafiante de un sentido común mercantilista y proyectado al logro de los más altos ideales que hicieron posible la creación misma del Derecho.

DAVID VALENCIA VillamizaR Editor Académico 


\section{INTRODUCCIÓN:}

\section{JUSTIFICACIÓN Y PRESENTACIÓN DE LOS TEMAS DE ESTA OBRA}

Trataremos en este primer espacio de justificar los temas centrales que aparecen a lo largo de este libro:

- Dios en el derecho aparece como una aspiración o intuición natural del ser humano; a través de toda la historia humana, y de la filosofía, Dios es objeto de reflexión y de acción; desde luego la divinidad incorrectamente concebida lleva a fanatismos nada deseables; pero de manera equilibrada, como aparece en el Preámbulo de la Constitución Política colombiana de 1991, parece sensata en la vida de los pueblos.

- Uno de los aspectos de la iusfilosofía es su historia trimilenaria; tratar de comprender esa historia es algo siempre luminoso para entender sus momentos y para proyectar el porvenir; en estas reflexiones trataré de ver el tiempo respectivo de sus escuelas y traerlo al presente; además, desde ya puedo expresar que la "tercera vía iusfilosófica" causa en mí personalmente una especial atracción, sin que por eso devalúe los aportes antecedentes a ella. Dicha tercera vía trata precisamente de encontrar, en lo posible, en los casos nebulosos, difíciles del derecho, el punto medio, aunque es de justicia decir que la teoría clásica del derecho natural, la aristotélica, habló con toda claridad de la equidad que es el equivalente al punto medio en el que tanto insiste hoy la tercera vía iusfilosófica. De otra parte, la complementariedad que busca la tercera vía en las dos anteriores es posible y justa a mi juicio en muchos aspectos así ello no sea posible en su raíz ontológica.

- Hablar del punto medio (como expresión máxima de la tercera vía iusfilosófica) es hablar de muchos filósofos antiguos, de ARISTóTELES ante todo, es hablar de la virtud, la cual es un referente arriba, alto, excelente, entre dos puntos extremos, en conflicto, y lejanos entre sí; es tarea difícil de lograr; por eso se denomina "virtud", sinónimo de esfuerzo, de fortaleza personal en su búsqueda; la virtud requiere eso, tenacidad en la búsqueda de la verdad para aproximarse a ella; no es 
mediocridad, desidia, pereza, no compromiso, relativismo absoluto; es un esfuerzo "hercúleo" (para decir una palabra apreciada por Kant refiriéndose a lo que es filosofar) para elevarse a la sabiduría; es tarea de todos los días hasta lograr hacer un hábito personal que "facilita" -que no es lo mismo que acostumbrarse rutinariamente-al logro de la equidad en todos las ámbitos humanos, y, desde luego, en el derecho; es cometido del Legislador como veedor de lo que debe ser el bien común de la polis, tarea del juez en los casos que se le sometan a su decisión, misión del jurista que litiga en la búsqueda de la defensa sincera y transparente de su cliente, y búsqueda del filósofo del derecho para tratar de llegar al fondo del derecho y a su realización.

Ahora bien, el punto medio no vale para todos los casos; hay casos en los que el derecho, por haber total claridad -aunque no son la mayoríano se requiere recurrir al punto medio; el punto medio, ya se dijo, es una herramienta para los casos nebulosos, oscuros, complejos, difíciles del derecho (y la moral).

El punto medio no vale tampoco para ciertos casos donde se debe apostar por una cierta radicalidad: la persona no admite puntos medios; hoy en día lo vemos por ejemplo en buena medida con los llamados "indignados" (en Europa); ahí hay que indignarse sin puntos medios.

El punto medio presenta una especial falencia cuando nos movemos entre casos o puntos de vista ideológicos "extremos", posiciones que podríamos llamar exageradas, y que, por serlo, podemos llamarlas viciadas; buscar ese punto medio equivale a buscar la equidad, el diálogo, la tolerancia, tan mencionada en estos tiempos pero tan poco vivida y por eso mismo tan necesaria. Desde luego, al hablar del punto medio siempre queda la sensación aparente de medianía y de falta de dialéctica; ante ello debo recordar, para lo primero -la medianía- que no se trata de neutralidad acrítica, ni de ser invertebrados jurídica (y éticamente), sino de ser respetuosos con los demás y de buscar lo excelente en lo personal; el respeto por el otro y la propia excelencia no tienen por qué excluirse; y respecto a lo segundo -la falta de dialéctica, método imprescindible en la filosofía en general y en la filosofía del derecho en particular-, debe recordarse que la dialéctica conduce a síntesis, a conclusiones, al menos parciales, y eso es justamente el punto medio.

El punto medio se presenta así como una "verdadera revolución": no es pasividad ni es desorden; no es ese quietismo que denuncia Vattimo, como sucede en Europa y en el mundo de hoy: "Nos han convencido de que si nos 
movemos un poco, todo se va a salir de curso"; pero tampoco es simple rienda suelta a las pasiones como el mismo autor reclama: "Yo soy un partidario del desorden: entre más desorden más felicidad", llegando a la conclusión de que no se puede creer en nada (2013, mayo 6); creemos que nada hay más beneficioso para el crecimiento humano que esa fuerza moral ardua de la búsqueda del punto medio entre extremos viciosos; fuerza moral beneficiosa para todo hombre de todo tiempo; es una de esas verdades adquiridas por la civilización humana; y no por ser un valor adquirido puede desdeñarse como algo del pasado en lo que no hay que creer simplemente con el argumento de que es del pasado. El mundo anda en una carrera sin sentido, donde todo vale pero nada vale al mismo tiempo, en una "lógica" irracional.

-Uno de los valores más sentidos hoy es el de la solidaridad, la fraternidad (no podemos negar que somos herederos de los ideales liberales del siglo XVIII: libertad, igualdad, fraternidad; de los tres, la cenicienta es el tercero; por eso vale la pena intentar impulsar ese ideal, esa utopía en el buen sentido de esta palabra), el compromiso por los demás, especialmente con el necesitado, el excluido, el pobre, el marginado, el explotado, el alienado, el miserable, el desventajado.

$\mathrm{Si}$, como se ha dicho, la filosofía del derecho es "una doctrina de la justicia" (Kaufmann, 2002, p. 39), el compromiso con los pobres resulta en consecuencia siendo una parte "esencial" de la iusfilosofía, y hoy retomada por los estudios llamados "críticos" del derecho (Critical legal studies y Filosofía crítica). La iusfilosofía sigue siendo filosofía metafísica, pero también es una filosofía práctica, vivencial, existencial, para la que se requiere no sólo del esfuerzo prudencial inicial del "ver" y el "juzgar" sino ante todo el esfuerzo "volitivo", el del "actuar", para hacer mucho, más aún, todo lo posible, por los necesitados; de nada serviría el "discurso" si no se pasara a la "acción".

Para Amartya Sen en este punto no bastan las "instituciones formales" liberales para lograr la justicia, sino que es menester además el "compromiso" real de las conductas de las personas (Sen, 2010, p. 13); y, Michael Sandel, en línea con el anterior, señala que la justicia es "hacer" lo que se debe (“Justicia ¿Hacemos lo que debemos?”), y, recordando y compartiendo a John Rawls, dice Sandel que éste propone que a los desventajados “... los tratemos aceptando 'compartir los unos el destino de los otros y sacar provecho de los accidentes y de las circunstancias sociales solo cuando redunda en el beneficio común'. Sea válida o no en última instancia esta 
teoría de la justicia -la de Rawls-, representa la defensa más atractiva de una sociedad más igual que la filosofía política haya producido jamás en Estados Unidos" (Sandel, Michael, Justicia, 2011, p. 189): lo cual es válido para otras latitudes como la latinoamericana.

- Tratando del fin del derecho, que es la justicia, nosotros decimos que no solo el derecho coadyuva a ella sino también la economía y la política en cuanto éticas y justas; dicho de otra manera, derecho, economía y política configuran un trípode para el logro de la justicia; derecho, economía y política, en cuanto justas las tres, forman entre sí una corriente circulatoria de justicia integral.

- Creo que el resumen de todo lo dicho hasta aquí es: el afán de una comprensión histórica complementaria de la iusfilosofía (tercera vía), que proporciona los referentes del derecho en conjunto, expresada por tanto en el punto medio aristotélico, virtud o equidad en el pensar y en el actuar jurídico; el compromiso especialmente por los pobres desde la iusfilosofía; y la necesidad del trípode derecho, economía y política, en sus aspectos justos propios, para la consecución final de la justicia.

\section{$* * *$}

Finalmente digamos en esta Introducción, que una obra como la que aquí presento se ubica en lo que se llaman ciencias del "deber ser", no tanto de lo que las cosas son en la realidad establecida por los hombres, sino de lo que debería ser; ésta no es una obra de "campo" (como la sociología) pero sí de reflexión teórica.

Ubicados aquí, digamos también que somos muy conscientes de que así como "el ser" tiene "intensidades" (es decir, hay seres que tienen más ser que otros; así por ejemplo, el hombre tiene más ser, más entidad, más importancia, que una piedra), también en el deber ser las hay (intensidades): unos captan una medida, otros otra, respecto a lo que debe ser la realidad (y concretamente el derecho para nuestro caso); lo que no se puede desconocer es que todo hombre no se queda "anclado" pasivamente a lo que las cosas establecidas por los hombres son como son en un momento determinado, sino que busca siempre un cierto "núcleo superior" de "deber ser".

Es algo similar a lo que ocurre en los valores, al menos siguiendo a Max Scheller: hay valores inferiores (los económicos) y valores superiores (religiosos). Por ello - por las diferentes intensidades del deber ser-, deben 
respetarse las visiones diversas, siempre y cuando no se sobrepase un "núcleo fundamental": así, por ejemplo, Gustavo Zagrebelsky dice que hoy en día el derecho constitucional es dúctil, pero debe haber un "mínimo" que no se puede violentar: ese mínimo es la pluralidad de valores y la lealtad en el enfrentamiento (Zagrebelsky, 2005, p. 14). 



\section{PREÁMBULO: \\ EL DERECHO Y DIOS ${ }^{1}$. VENTANA A LA TRASCENDENCIA.}

Comienzo el preámbulo de este libro a la manera como la Constitución Política de Colombia de 1991 también empieza con el suyo; un preámbulo es una puerta de entrada interesante para ver las cosas panorámicamente y como arca de valores; el preámbulo constitucional dice así:

\section{"Preámbulo}

\section{El pueblo de Colombia}

En ejercicio de su poder soberano, representado por sus delegatarios a la Asamblea Nacional Constituyente, invocando la protección de Dios, y con el fin de fortalecer la unidad de la Nación y asegurar a sus integrantes la vida, la convivencia, el trabajo, la justicia, la igualdad, el conocimiento, la libertad y la paz, dentro de un marco jurídico, democrático y participativo que garantice un orden político, económico y social justo, comprometido a impulsar la integración de la comunidad latinoamericana decreta, sanciona y promulga la siguiente

\section{Constitución Política de Colombia"}

$$
* * *
$$

Quiero iniciar este libro con el preámbulo anterior, que, a mi parecer es radicalmente significativo en el tema de la relación Derecho y Dios, aunque también podemos apoyarnos - por citar otro preámbulo, ya no latino-emocional sino tradicionalmente racional como es Alemania-, en la Ley Fundamental de la República Federal de Alemania del 23 de mayo de

1 Conste aquí que no estoy con esto manifestando mi percepción de Dios; sólo estoy trayendo a colación un tema que considero de importancia para el derecho y que merece un tratamiento iusfilosófico. 
1949, que en su Preámbulo también cita a Dios como factor esencial de la juridicidad de la siguiente manera:

"Consciente de su responsabilidad ante Dios y ante los hombres, animado de servir a la paz del mundo, como miembro con igualdad de derechos de una Europa unida, el pueblo alemán, en virtud de su poder constituyente, se ha otorgado la presente Ley Fundamental" (Bundestag alemán, Berlín, 2009, p. 13).

Dicho lo anterior podemos formular estas cuestiones: ¿Es un asunto fundamental la presencia de Dios en el derecho? ¿Dios es un tema central de la iusfilosofía? Tratemos de dar una respuesta porque desde luego es de alguna manera sorprendente que un libro como éste aborde tal tema, el cual a primera vista, además, pareciera ser más un tema de filosofía política que de iusfilosofía.

Tratar del Preámbulo de la Carta Política es tratar de un tema hasta ahora virgen y en cierta medida riesgoso; y ni qué decir de abordar el tema de la Divinidad en el derecho por la tan arraigada pretensión de autonomía del mismo (pero ello en realidad no debería extrañar dada la "complejidad" de las ciencias tan aceptada también hoy en día (Morin, 2001, p. 40)); se agrava además el asunto por los excesos patentes de las religiones, que las hacen a veces molestas [para lo cual bastaría ver noticias como la de los chechenios que hicieron explotar una bomba en la Maratón de Boston, Estados Unidos, causando muertos, heridos y pérdidas materiales, todo hecho "en nombre del Islam” (2013, abril 24); igualmente el día de la publicación mencionada, una columna de opinión de Carlos Castillo Cardona, en la p. 21, titulaba su reflexión "En el nombre de Dios", haciendo alusión a los excesos de la utilización de Dios; o el problema yihadista más actual; por fortuna el tema de las guerras de religión no es un tema problemático en Colombia ni en general en Latinoamérica].

De lo anterior podríamos extraer la necesidad de que ambas realidades, religión y derecho, se retroalimenten, pues la "razón" puede ayudar a la "fe" y ésta a la razón, en los excesos de cada una. Ello resulta un tema actual de importancia.

La relación entre el hombre y Dios concierne principalísimamente a la religión (o religiones), pero el derecho puede aportar su cuota en esta materia; es precisamente lo que hacen los Preámbulos constitucionales colombiano y alemán. Y es además un asunto del derecho de las mayorías (hoy las minorías pareciera que son las que más se abren camino en el mundo del derecho); por eso mismo, entonces, es un tema que afecta a la iusfilosofía, ésta no puede pasar desapercibida ante tales fenómenos. 
Pareciera que el Preámbulo no pasa de un menú de "buenas intenciones" pues ha sido arrinconado.

Pues bien, por el contrario lo abordaré en las siguientes líneas. Esta iusfilosofía, desde el principio, la empecé a escribir con ánimo "comprometido", y nada más comprometedor que este tema (recuerdo una ocasión en la que el Director del Departamento de Humanidades de una Universidad me dijo que si aceptaba hablar a un grupo de profesores sobre la existencia de Dios dado que nadie se había animado; ante tal situación decidí aceptar el reto, con entusiasmo y también casi que por conmiseración con ese Director; no me fue mal afortunadamente; en esta ocasión se repite el compromiso desde otra perspectiva, la iusfilosófica); me la juego; sé que puede suscitar inquietudes.

Desde hace tiempo la presencia de Dios en el derecho me inquieta, me llama la atención, me parece fascinante e importante.

¿Es posible esa presencia?: Sí, y para la muestra, los anteriores botones de los Preámbulos de nuestra Carta Política y también de la Ley Fundamental de Alemania de 1949.

El Preámbulo de la Constitución Política de Colombia de 1991 expresa esa presencia divina desde el puro comienzo, dando a entender su significancia mediante una "invocación" a Dios.

Hobbes trata "del Reino de Dios por naturaleza" - por el contrario al Preámbulo-, en su último capítulo de Leviatán; pero ello no quiere decir que para Hobbes la presencia de Dios en la política y el derecho no sea importante; trata el tema como cerrando con buen candado su magna obra de filosofía político-jurídica: así, el culto a Dios es para Hobbes algo capital; leámoslo directamente:

"Pero viendo que una república no es sino una persona, sólo debe exhibir a Dios un culto, y así lo hace cuando ordena que sea mostrado públicamente por los particulares. Y esto es el culto público, cuya característica es ser uniforme. Pues aquellas acciones que se hacen de modo distinto por hombres diferentes no pueden considerarse un culto público. Y, por tanto, allí donde se autorizan muchos tipos de culto, procedentes de las diversas religiones de los particulares, no puede decirse que exista ningún culto público ni que la república tenga religión en absoluto" (Hobbes, T., Leviatán, 2004, cap. XXXI, p. 308).

Rousseau, tratando también el tema de la Divinidad en el último capítulo del Contrato social -pero que no por ello es de poca importancia para la política y el derecho-, y siguiendo más en detalle esta idea de Hobbes del 
culto "uniforme" a Dios, llega a erigir la denominada "religión civil"; así, después de descartar la "religión del hombre" (la del puro Evangelio, que descarta Rousseau como religión del Estado porque la religión de Jesús no es de este mundo), de descartar también la "religión del ciudadano" (la de un solo país, con culto exterior determinado por las leyes, pero que descarta por ser supersticiosa y ahogar el culto a Dios en un mero ceremonial), y de descartar igualmente la religión del "cristianismo romano" (que descarta simplemente por ser mala por sí), habla de una confesión religiosa puramente civil cuyos artículos deben ser fijados por el soberano, enunciados de manera muy precisa, sin interpretaciones, donde se acepta una divinidad poderosa, inteligente, bienhechora, previsora, providente, que trata de una vida futura, de felicidad, de justos, del castigo de los malos, y de la santidad del contrato social y de las leyes (Rousseau, 2009, pp. 208 y ss.).

Hechas esas citas tan venidas a nuestro tema-las de Hobbes y Rousseau-, volvamos sobre el texto de nuestro Preámbulo.

Invocar a Dios es pedirle allí su ayuda.

Pero... ¿qué "juridicidad” y "obligatoriedad” tiene ese Preámbulo y esa invocación?

¿No debe pasar de una oración para ayudar a lograr los objetivos que se trazó, a saber, "La unidad de la Nación, asegurar a los integrantes de la Nación la vida, la convivencia, el trabajo, la justicia, la igualdad, el conocimiento, la libertad y la paz, dentro de un marco jurídico, democrático y participativo que garantice un orden político, económico y social justo, y comprometido a impulsar la integración de la comunidad latinoamericana"?

A mi juicio, debiera tener más implicaciones. No debe quedarse esa oración a Dios en "letra muerta", en algo que se hizo quizá con mucho convencimiento y entusiasmo el día de la promulgación de la Carta en 1991 porque, por fin, teníamos una Constitución nueva, hecha por diferentes partidos políticos, después de una Constitución monopólica de raíz conservadora.

Todo, porque ese fue el deseo del "Pueblo de Colombia" en aquél año de 1991.

No fue el deseo de "todo" el pueblo colombiano, pues hay ateos confesos. Ahora bien, esa invocación no debe sorprender porque la historia demuestra la "religiosidad natural" del hombre (como lo dan a entender implícitamente Hobbes y Rousseau), así como la mayoría religiosa del país (y no se puede perder de vista que las mayorías en general tienen, las más de las veces, una importancia capital; pero me refiero a mayorías sensatas y no a mayorías 
desbordadas como la historia ha demostrado por ejemplo en el caso del apoyo a Hitler; porque no por tratarse de mayorías allí está toda la verdad).

¿Por qué Dios en el derecho, en la Constitución Política? Sigamos preguntándonos.

- No se trata de incurrir nuevamente en las mescolanzas de poder terrenal y poder religioso del pasado histórico: ¡ni hablar de eso!; eso por fortuna está superado (ojalá del todo).

- No hay que volver tampoco a épocas en que abusivamente se decía que las sentencias en derecho eran en el "nombre de Dios": ¿quién es el hombre para arrogarse ese derecho?

- No se trata tampoco de neoteocracias.

- Ni se trata tampoco de incluir a un Dios concreto de una determinada religión, en el derecho constitucional; no me gustan los confesionalismos religiosos. ¡Qué horror comprometer a Dios con cuestiones políticas! ¡Pobre Dios!

- Se trata, sí, de libertad religiosa como derecho fundamental. Eso es todo lo que le compete al derecho: garantizar dicha libertad.

- Se trata también del encuentro fraternal de las distintas creencias religiosas (me acuerdo del Templo de todas las religiones que conocí en la Clínica Mayo, de Rochester, en E.U., o también del día de Acción de Gracias en EE.UU). A eso, y otras concreciones posibles, debe llevar la presencia de Dios en la política y en el derecho constitucional.

Eso fue, además, lo que quisieron los fundadores del Estado moderno y de la democracia moderna, desde Hobbes - quien por cierto tampoco quería la intromisión del poder religioso en el poder político, tal como lo dijo en Leviatán-, pasando por Rousseau y por los padres fundadores de Estados Unidos de Norteamérica [bastaría leer un aparte de la Declaración de Independencia de los Estados Unidos de Norteamérica que dice:

\footnotetext{
"Cuando en el curso de los acontecimientos humanos se hace necesario que un pueblo rompa los lazos políticos que lo han unido a otro, para ocupar entre las naciones de la tierra el puesto de independencia e igualdad a que le dan derecho las leyes de la naturaleza, y el Dios de esa naturaleza, el respeto decoroso al juicio de la humanidad exige que declare las causas que lo han llevado a la separación. Sostenemos como verdades evidentes que todos los hombres nacen iguales; que a todos les confiere el Creador ciertos derechos inalienables..." (Don Antonio Nariño el precursor, Universidad Militar Nueva Granada, enero-junio de 1993, pp. 16-17)].
} 
Estados Unidos da ejemplo de esa presencia de la Divinidad en su Derecho y en su Política; no les da vergüenza confesar a Dios públicamente (pero quede claro por demás que no soy un doblegado ante todo lo que sea E.U., pero en eso es plausible).

Ahora bien, cabe preguntar otra vez: ¿cuál Dios? Pues... simplemente Dios, la idea de Dios como intuición humana elemental, que todas las culturas tienen, que tuvo Rousseau cuando habló del Dios bienhechor, providente. No un dios malo que autoriza, por ejemplo, matar en su nombre como ha ocurrido en la historia occidental y como está ocurriendo en Oriente ahora.

Por último digamos que no basta la invocación periódica a Dios, como hemos propuesto atrás.

La presencia de Dios se consigue no sólo con invocarlo; esa presencia de Dios se consigue sobre todo con la colaboración del hombre con la defensa de los derechos del hombre y con la defensa de la naturaleza.

Todo ello junto conforma un trípode básico: plegaria, respeto de los derechos humanos, y guarda de la naturaleza física.

Las "autonomías absolutas" en las esferas del derecho y de lo político deben quedar rezagadas. En esta materia cabe un punto medio sano: ubicarse entre un ateísmo oficial, por una parte, y el clericalismo, el fundamentalismo religioso, la teocracia, por otra. Es posible lograrlo para bien de la democracia y el derecho.

Se trata en definitiva:

- De defender el Estado laico frente a los Estados confesionales.

- De reconocer que la concreción de lo divino en el mundo jurídicopolítico es múltiple: invocación de la Divinidad de las mayorías (es su derecho), y, defensa de los derechos humanos y de la naturaleza.

- De reconocer que para una democracia el derecho a la libertad de religión es fundamental y básica para el orden jurídico.

Sirva lo anterior entonces a manera de preámbulo de estas reflexiones. No hemos querido dejar pasar por alto el Preámbulo de la Constitución Política de 1991 en la materia; la iusfilosofía puede decir algo al respecto. 


\section{SENTIDO O LOGOS DE LA IUSFILOSOFÍA}

A. SENTIDO DIFÍCIL, PERO SIEMPRE VALIOSO, DE LA FILOSOFÍA Y DE LA FILOSOFÍA DEL DERECHO

"Lo que deja de pensarse cualitativamente para pensarse cuantitativamente deja de pensarse significativamente"

(Nicolás Gómez Dávila)

Para tratar de entender la filosofía del derecho es muy útil adentrarse en su misión. Es un buen comienzo.

¿Podemos conocer lo invisible? ¿Vale la pena ese ejercicio, sobre todo hoy, cuando todo nos entra por los ojos del cuerpo? (Giovanni Sartori afirma que vivimos una época del "homo videns") ¿Pero no es esa la tarea de la filosofía, esto es, tratar de conocer lo invisible para los ojos del cuerpo, aunque partiendo de ellos, pues tenemos capacidades superiores? Pero, ¿qué podemos suponer que es lo invisible?

Para los ojos corporales el derecho aparece visible: en efecto, hay leyes escritas, costumbres que se practican, jueces, sentencias escritas... Pues bien, la filosofía del derecho, si va a lo invisible como filosofía que es, es decir, pretende lo "metafísico", debe ir más allá de lo visible del derecho; la filosofía del derecho supera a lo visible del derecho, es más profunda que el derecho escrito, trata de ir al fondo del derecho. Ahora, jes que existe un fondo del derecho más allá de las leyes escritas, de las sentencias? Ya lo veremos, esa es la tarea que se propone la iusfilosofía.

Digamos quizá osadamente que la filosofía preside y precede al derecho; si nos parece demasiado osada la anterior afirmación entonces digamos que la filosofía al menos acompaña al derecho en su caminar: esa es la filosofía del derecho; o es eso o no sirve para nada; la filosofía, pues, busca fundamentar, o acompañar al menos, al derecho.

Hoy en día el derecho se siente autónomo plenamente, no quiere o ignora ser complejo, es decir, tener la capacidad de relacionarse con otras ciencias 
y ayudarse mutuamente. Relacionarse unas ciencias con otras para la "teoría de la complejidad" es algo natural, lógico. El derecho, en esa atmósfera autonomista mencionada, parece también sentirse autosuficiente; y uno de los expedientes para su autosuficiencia es, a mi juicio, el derecho constitucional; la sola expresión constitucional parece darle la razón a esta afirmación autonomista del derecho: el derecho constitucional desde esta perspectiva le daría todo su ser al derecho. Y otro tanto dígase de los llamados derechos humanos: ¿para qué más? ¿Para qué filosofía del derecho si el derecho constitucional y los derechos humanos son el todo del derecho?; esos serían los núcleos más íntimos del derecho: los derechos humanos tal como los diga la Constitución Política, o los interprete un Alto Tribunal Constitucional.

Sin embargo, la pretensión de la filosofía del derecho ha sido ir más allá del derecho visible; la filosofía del derecho no sería una ciencia cerrada en sí misma, normativista; el derecho no se circunscribiría a lo que Hans Kelsen llama el "derecho puesto"; el derecho, así, sería una ciencia autónoma, pero no "plenamente" autónoma; la filosofía del derecho, entonces, fundamentaría al derecho, o, al menos, lo acompañaría, en este orden de ideas.

Sin embargo podemos seguir preguntándonos: ¿ha sido así realmente, es decir, fundamenta la filosofía del derecho al derecho "puesto"? La respuesta es que no siempre, a decir verdad, pues el iuspositivismo y la llamada Teoría del Derecho ha sido un intento, en su origen y en un largo trecho de su desarrollo, de encerrar al derecho en el derecho puesto; contrario a ellas la filosofía del derecho ha pretendido, tal como acabo de decir, ir más allá del derecho puesto: lo fundamenta en algún grado, es ciencia que anuncia lo que es más auténticamente el derecho, busca su sentido más profundo, lo orienta hacia valores que deberían ser alcanzados por la civilización, busca universalizar al derecho como realidad humana noble; todo ello se ve en la elaboración de conceptos tales como naturaleza humana (útil para el derecho), principios del derecho, justicia, libertad, igualdad, paz, solidaridad, etc., que, aunque el derecho los incorpora en alguna medida en sus normas propias, tienen su asiento más profundo y radical en la filosofía del derecho.

Lo que se acaba de decir no deja de ser una extravagancia, una exageración para alguna parte del mundo jurídico de hoy, casi que una ofensa para el derecho según algunos, tan cargado de autonomismo, de constitucionalismo, de derechos humanos encerrados en sí mismos en su enunciación escrita; por eso el derecho requiere de otra referencia, de apertura, para aceptar esa afirmación: la de que la filosofía supera al derecho puesto, va más allá de él, así parta de él muchas veces porque es su materia prima. 
Ahora bien, ¿la filosofía del derecho tiene a pesar de eso, cabida en la actualidad? ¿Es necesaria la otra referencia para el derecho? Cuando asistimos a una época de lo visible, que sólo cree en lo que ve con los ojos corporales, de la imagen tecnológica, parece tarea difícil aceptar que una ciencia sea vista por otra con ojos de fundamentación o al menos de acompañamiento; pero eso no debería extrañar, se repite otra vez, si vemos las cosas desde la llamada "teoría de la complejidad" que pretende interrelacionar a las ciencias entre sí; y más difícil es aceptar la influencia de la filosofía en el derecho si vemos las cosas desde la jerarquía clásica de los conocimientos, tal como sucedió en la antigüedad con la "pre-eminencia" de la filosofía respecto de los demás conocimientos.

Empero, las jerarquías no nos deberían tampoco sorprender tanto pues hasta en el mismo derecho existen: se dice, por ejemplo, que la Constitución es "norma de normas" (Const. Colombia, art. 4, 1991); se dice igualmente en la Constitución Política que los derechos de los niños "prevalecen" sobre los de los demás (art. 44).

El panorama se complica, además, si pensamos en lo siguiente: aceptemos que el derecho debe fundamentarse en la filosofía; está bien, pero... ¿cuál filosofía? ¿No son las filosofías dispares entre sí? Y si se trata de filosofías del derecho... ¿no son opuestas la filosofía realista y la filosofía positivista?

Creo que una respuesta a ese laberinto de filosofías nos lo brinda Ortega y Gasset cuando critica a la filosofía que domina desde Kant -sí, nada menos que con Kant-, que se convirtió, para Ortega y Gasset, en simple "teoría del conocimiento", desconociendo 26 siglos de "metafísica" (sí, se trata para el filósofo español de volver a valorar la metafísica); pero leamos mejor sus propias palabras:

“Agobiado por tal predominio (el de la física), el filósofo se avergonzó de serlo, es decir, se avergonzó de no ser físico. Como los problemas genuinamente filosóficos no toleran ser resueltos según el modo de conocimiento físico, renunció a atacarlos, renunció a su filosofía contrayéndola a un mínimum, poniéndola humildemente al servicio de la física. Decidió que el único tema filosófico era la meditación sobre el hecho mismo de la física, que la filosofía era únicamente teoría del conocimiento. Kant es el primero que en forma radical adopta tal actitud, no se interesa directamente en los grandes problemas cósmicos, sino que con un gesto de policía urbano detiene la circulación filosófica -veintiséis siglos de pensamiento metafísico- diciendo: 'Quede en suspenso todo filosofar mientras no se conteste a esta pregunta: ¿cómo son posibles los juicios sintéticos a priori?' Ahora bien, los juicios sintéticos a priori son para él la física, el factum de la ciencia físicomatemática" (Ortega \& Gasset, 2007a, pp. 60-61) [esta afirmación la 
comparte también Manuel García Morente al decir: “...la teoría del conocimiento significa para él (Kant) la teoría de la física matemática de Newton" (García, 1952, p. 234), añadiendo: “...Kant abre un nuevo período (filosófico). Habiendo establecido Kant un nuevo sentido del ser, que no es el ser 'en sí', sino el ser 'para' el conocimiento, el ser en el conocimiento, abre Kant un nuevo período para la filosofía, que es el período de desenvolvimiento del idealismo trascendental que llega hasta nuestros días" (1952, pp. 228-229)].

Volviendo a Ortega, dice: "Conocer es no contentarse con las cosas según ellas se nos presentan sino buscar tras ellas su 'ser"' (Ortega \& Gasset, 2007b, p. 79); es lo que hemos venido exponiendo antes.

La respuesta orteguiana que considero venida como anillo al dedo para el laberinto expuesto de qué hacer ante las varias filosofías, es, sin embargo, no un objetivismo puro: el ser "en sí". En el contexto de su obra, podemos entrever con toda claridad que se trata de una posición que podríamos llamar más bien "mixta": objetividad y subjetividad concomitantemente.

Leamos unas palabras suyas a este respecto: "Para nosotros, la vieja discordia (realismo/racionalismo) está resuelta desde luego; no entendemos cómo puede hablarse de una vida humana a quien se ha amputado el órgano de la verdad, ni de una verdad que para existir necesita previamente desalojar la fluencia vital" (Ortega \& Gasset, 2010, p. 90).

Esa es pues la tarea de la filosofía hoy, que creemos "más acertada", y que vamos a tratar de seguir en este curso: una hermenéutica equilibrada: una filosofía del ser "en sí" (objeto) y del ser "en mí" (sujeto), una filosofía mixta, sumante, ecléctica, hermenéutica, del punto medio.

Así las cosas, esto es, ir más allá de lo visible, afirmamos que la filosofía del derecho es algo cualitativo, no es algo solo cuantitativo como puede ser en buena medida la sociología jurídica (que se construye en base a datos, estadísticas, sondeos...), o la misma legislación (que se basa en ponencias escritas u orales, debates, votaciones, aprobaciones...).

La filosofía del derecho tiene entonces una significación especial -para seguir la frase inicial de Gómez Dávila que preside este acápite-: es prejurídica o al menos co-jurídica aunque el derecho puesto sea su materia prima (y, a veces, o la mayor parte de las veces, su expresión).

Pero el derecho requiere, a su turno, de una capacidad especial para aceptar que la filosofía le diga algo que tiene que ver con sus orígenes, con su totalidad, con lo universal, con sus valores, con sus fines, con su dinámica más profunda (Noguera, 2002a); y no sólo requiere esa capacidad el derecho 
respecto de la filosofía, sino que el jurista por su parte requiere de una dotación especial, un hambre: ir al fondo del derecho, no quedarse con lo visible, con lo fenomenológico, con lo aparente, con lo legal, con las meras sentencias; el jurista debe ir más allá de la mera legislación y de la mera jurisprudencia, debe preguntarse por el origen más íntimo del derecho, por lo más intocable, intangible de él, por el hombre en sí mismo para quien existe el derecho, por su dignidad suprema, por la libertad humana con fronteras razonables, por la comunidad humana...

B.

SENTIDO E IMPORTANCIA DE LA FILOSOFÍA DEL DERECHO (CONTINUACIÓN).

"La filosofia del derecho responde a una evidente necesidad de la inteligencia y de la cultura, que no pueden contentarse con la mera presencia formal de los códigos, las leyes, las sentencias, y las instituciones jurídicas. Más allá de los textos legales o de los hechos concretos, el espiritu humano no puede menos de formularse una serie de cuestiones relativas a los fundamentos, la esencia, la finalidad y el valor,

que sólo puede contestar la Filosofía del derecho"

(Hüber Gallo)

En las anteriores palabras de Hüber Gallo queda retratada de cuerpo entero el sentido, o al menos uno de los sentidos, de la filosofía del derecho. Son palabras que empalman con lo que dijimos atrás: la filosofía, y la filosofía del derecho (que es una rama de la filosofía), deben ir más allá de lo visible; el hombre con verdadero espíritu filosófico no se contenta con las apariencias fenomenológicas, así parta muchas veces de ellas.

La filosofía es nativamente metafísica, esa es su esencia y característica primigenia; sin metafísica simplemente despojamos a la filosofía de su razón de ser más originaria; sin metafísica la filosofía se torna en otra cosa: en sociología, en Teoría del derecho, en cualquier otra ciencia, menos en filosofía; y, lamentablemente a mi juicio, esa es la tendencia actual: eliminar a la filosofía en cuanto metafísica; el espíritu, o mejor, la tendencia de hoy -aunque de hace ya algún tiempo considerable-, es la exaltación de la ciencia exacta, del número, del conteo, de la estadística; sin embargo, defendemos a la filosofía en tanto en cuanto es la respuesta de un anhelo del hombre, del anhelo de lo invisible, de lo que está más allá de las puras apariencias visibles, de un tratar de dar respuesta a lo escondido (en el buen sentido de 
esta palabra), de responder a las preguntas más trascendentales del hombre aunque las respuestas sean meros atisbos, aproximaciones, tanteos. El hombre por más que alcance muchas certezas físicas siempre tendrá un margen y un núcleo mistérico pues su espíritu es insondable.

Nos parece de gran importancia por razones de presentación de la iusfilosofía, hablar del logos de la filosofía del derecho; quiero decir con lo anterior, que, sobre todo para el iniciante de la filosofía del derecho -y todos somos de alguna manera iniciantes-, a veces ésta puede presentarse como inútil, innecesaria, y más en estos tiempos, pragmatistas, cientificistas, donde pareciera que lo único importante es lo inmediato, lo práctico, el resultado empírico (y dinerario); por el contrario, la iusfilosofía es meditativa, metafísica, pausada, lenta, no de resultados visibles de manera inmediata. Su utilidad primera radica en una aspiración profunda del hombre cual es ir lo que se considera primero de la realidad del derecho.

Ahora bien, acotar la misión de algo, que para nuestro caso es la de la filosofía del derecho, es un punto con alguna dificultad; sin embargo trataré de hacerlo de la manera más sencilla: ¿qué es logos? Para dar una idea inicial podemos decir que logos es tarea, cometido, trabajo. ¿Cuál es entonces la tarea o cometido de la iusfilosofía? Trataré este tema en tres perspectivas:

a. Algunos abordan ese logos por buscar directamente el fundamento del derecho (Noguera, 2002b, pp. 16-17).

b. Otra manera de afrontar el sentido de la iusfilosofía es viendo los "temas" o "problemas" principales que abordan los iusfilósofos en sus "obras", en sus libros y artículos; por los problemas tratados se deduce el sentido de la iusfilosofía: el origen primero del derecho, el derecho natural, el derecho positivo, la relación moral y derecho, la norma básica, la justicia, la historia de la filosofía del derecho, los derechos humanos, la hermenéutica jurídica, los valores y fines del derecho, una preocupación por un derecho de tinte social, etc.

Ahora bien, se debe señalar que con lo inmediatamente anterior (literal b) va apareciendo que el sentido de la filosofía del derecho es cambiante, dinámico, histórico; desde luego hay temas "eternos", siempre presentes, pero abordados, de una manera u otra, según ciertas tendencias y circunstancias históricas (MejÍA \& EnCINALES, 2011) en el último capítulo aparecen las nuevas tendencias sociales de la filosofía del derecho); ello significa que el sentido de la iusfilosofía va acorde con los tiempos, no se paraliza, debe estar atento a lo que le aporta la sociedad, aunque siempre mirando al derecho con mirada integradora, universal, filosófica. 
c. Quisiera dejar expuesta otra misión de la iusfilosofía, derivada de los "métodos" de la filosofía. Desde luego, esto conecta con el literal a) anterior pero quisiera ser más explícito con el punto atinente a los métodos.

La iusfilosofía se apoya en los métodos que la filosofía ha utilizado siempre a fin de llegar a la esencia del derecho (o metafísica del derecho): responder a la pregunta ¿Qué es el derecho?, es tarea primordial de la iusfilosofía; pues bien, dichos métodos coadyuvan a lograr una respuesta aproximativa a dicha pregunta.

Utilizando esos métodos la filosofía del derecho ha dado respuesta a la pregunta acerca de qué es el derecho desde tres grandes filosofias: la "realista", que afirma que el derecho es un conjunto de normas enraizadas en la naturaleza humana; la "idealista", que dice que el derecho es la voluntad normativa expresada por el legislador; y la "tercera vía iusfilosófica", que dice que el derecho es, ante todo, lo que digan los jueces de la manera más justa posible.

De momento no veremos en detalle estas posturas (lo haremos en el capítulo dedicado a la historia de la iusfilosofía), pero sí haré una breve referencia a continuación a los métodos de la filosofía general:

- La filosofía cuenta entre sus métodos con la "mayéutica", la pregunta, socrática (García, 1952a, p. 20); pues bien, la iusfilosofía debe siempre tener esa "actitud", esa tarea, esa misión: preguntarse de dónde viene el derecho, o cómo va el derecho positivo en relación con sus fines y valores; la iusfilosofía no pasa desapercibida ante los fenómenos del derecho positivo, las sentencias de los jueces, las leyes que se promulgan o los proyectos legislativos, y los hechos sociales que afectan o pueden afectar al derecho. La iusfilosofía no es insensible a todo eso. Y cuánta importancia tiene también la pregunta, existencialmente hablando, acerca de la tarea diaria del juez en los casos concretos.

- La filosofía cuenta entre sus métodos también con la "dialéctica" platónica (García, 1952b, p. 21), la “disputatio" medieval escolástica (p. 25), la oposición, la crítica; por eso Hüber Gallo dice que la filosofía del derecho "Somete a crítica al derecho positivo vigente desde el punto de vista de criterios estimativos superiores, señalando el valor de las leyes y abriendo camino para las reformas" (Noguera, 2002, p. 17).

- Otro método es el de la "lógica" formal del silogismo (García, 1952c, p. 24), y las lógicas modernas, de gran cuño "existencialista”, vivencial (filosofía nacida en el siglo XIX ante todo con Soren KIERKEGAARD), 
como la "lógica borrosa", nacida en los años 60s, de Bart Kosko, donde los fenómenos no son vistos como negros o blancos, de manera disyuntiva y radicalmente opuestos, sino que son precisamente borrosos, vivos (Goñi, 2003, p. 29), muy del mundo del derecho vivo, actuante en los pleitos, en los juicios, precisamente por tratarse del hombre que es enigma; o la lógica llamada "informal", que trata del arte de la argumentación, partiendo de premisas fiables, evitando un lenguaje puramente emocional, basándose en palabras claras, en fuentes cualificadas, eludiendo los ataques personales en la dialéctica (Goñi, pp. 30-31), muy propia del arte del abogado, aunque también del juez.

- Otro método siempre vigente de la filosofía es la "duda"; Descartes, incierto de los conocimientos de su época (y desde antes del siglo XVII), conocimientos desvalorizados por los nuevos hallazgos sobre todo científicos, "duda" de los conocimientos hasta entonces existentes; pero desea llegar a un conocimiento cierto, verdadero, más allá de quedarse estancado en la duda; $y$, dudando, llega a la convicción de que lo único de lo que no puede dudar es de que está dudando, duda que radica en el pensamiento humano; y así llega a su gran dogma filosófico: "pienso, luego soy", "cogito ergo sum"; la duda pues se elevaba a la categoría de método, pero no para estar siempre en la duda, sino para llegar a una verdad indubitable. La duda es sólo camino, no fin.

- Igualmente la iusfilosofía debe apoyarse para su tarea y misión en el método de la "intuición"; este método propio de la Modernidad, fue desarrollado de manera muy intensa por los "románticos" alemanes del siglo XIX (como Schelling, Hegel, Schopenhauer, Fichte), también llamados "idealistas" alemanes; ellos, suponen dos momentos en el conocimiento: a) uno de "inmanencia mística", de descubrimiento de una "verdad absoluta", en la cual se apoya todo (por eso el nombre de idealistas y románticos, aunque no debería sorprendernos mucho pues esa es la tarea de la filosofía desde su nacimiento, donde la verdad última radica en el "agua"-Tales de Mileto-, o en el número Pitágoras-, etc.); b) y otro, según el cual, a partir de ese hallazgo místico en el que todo se apoya, se desprende toda una "teorización", "unas filosofías" sobre diversos aspectos, como el hombre, la naturaleza, el derecho, etc., no basado en la experiencia, sino en el puro pensamiento inmanente (por eso se llama intuición) (García, 1952). 
Ahora bien, esta intuición será desarrollada por los filósofos a través de tres "impulsos" o actitudes humanas: a) la "intelectual" propiamente dicha (intuición intelectual), por medio de la cual se quiere llegar a la "esencia" de los objetos que se pretenden conocer; b) a través de la "emotividad" (intuición emotiva), pretendiendo encontrar el valor de los objetos que se conocen; c) y a través de la "voluntad" (intuición volitiva), pretendiendo encontrar la existencia, lo que está ahí de los objetos que se buscan encontrar, de manera esforzada, vivida (García, Morente et al.).

Si nos fijamos un instante, podemos deducir que esas tres actitudes responden a las tres grandes distintas "psicologías" humanas: unos son intelectuales, otros son emotivos, y otros son voluntariosos.

Esos tres impulsos han encontrado su paralelo, su correlato, en la filosofía del derecho: a) así, la intuición intelectual en derecho encuentra su expresión, por ejemplo, en el iusnaturalismo de la Modernidad, sobre todo en los logicistas racionalistas (que dicho sea de paso posteriormente llevaron al iuspositivismo); b) la intuición emotivista encuentra su expresión en la iusfilosofía a través de los defensores de "valores" en el derecho (es la "axiología jurídica"); c) y, la intuición volitivista, encuentra su manifestación en la iusfilosofía ante todo en la denominada tercera vía iusfilosófica, que ve el derecho sobre todo como "derecho judicial", vivo, actuante por medio de las sentencias de los jueces; el derecho es, como diría Alvaro D’Ors, lo que aprueben los jueces (Escritos varios sobre el derecho en crisis, pp. 45 y ss.).

"Las cosas que hacen de alguien un buen juez o un buen intérprete de leyes son, en primer lugar, un recto entendimiento de esa ley natural básica llamada equidad que (no dependiendo de la lectura de los escritos de otros hombres sino de la bondad existente en la propia razón natural de un hombre y en su meditación) se supone máximemente presente en quienes han tenido más ocio y más inclinación a meditar sobre el tema"

(Thomas HoBbes).

Si se da cuenta el lector, lo que se acaba de decir en el literal anterior, deja la obvia idea de que el sentido de la filosofía del derecho es puramente "formal": el lenguaje del sentido de la iusfilosofía es expreso, o, tácito, por 
una parte, y, los métodos de la iusfilosofía son los mismos métodos de la filosofía general, pero al fin y al cabo métodos, caminos formales, más no la verdad misma, la verdad con contenido.

Pues bien, el sentido de la iusfilosofía, tal como se dijo en el pensamiento introductorio de Hüber Gallo citado al principio, debe ser ante todo de fondo, de contenido; sentido de la iusfilosofía es criticar el derecho positivo; pero... ¿con base en qué?

Pues precisamente el punto de referencia para examinar, cuestionar y criticar al derecho positivo es el de los "referentes materiales del derecho" que veremos en el capítulo siguiente; conocerlos es decisivo y aplicarlos es una labor hermenéutica ardua pero que vale la pena (¡lo que vale cuesta!), como toda labor interpretativa en el derecho (pues está en juego nada menos que su meta que es la justicia).

¿Es “válido" el derecho positivo? Pues esa validez "intrínseca" - no formal, tarea que le corresponde al derecho ordinario- depende de su legitimidad, legitimidad que debe mirarse armoniosamente "desde" o "a partir de" el bien integral de la persona humana, de la familia, de la sociedad, de la naturaleza, y del Estado (tales son, como los hemos denominado, los "referentes materiales del derecho").

Esta "hermenéutica" es para nosotros la del "punto medio", la del punto de equilibrio, de armonía, tal como dejaron como legado perenne los hermenéuticos de todos los tiempos, y los actuales: desde Pitágoras y Aristóteles, en la antigüedad, hasta Kaufmann y Beuchot en nuestro tiempo; por eso, más adelante volveremos sobre este tema al tratar de la hermenéutica dentro de la tercera vía iusfilosófica.

D. UNA DIGRESIÓN NECESARIA EN MATERIA DE SENTIDO: TECNOLOGÍA Y FILOSOFÍA

"El hombre se está acostumbrando a aceptar pasivamente una constante intrusión sensorial. $Y$ esta actitud pasiva termina siendo una servidumbre mental, una verdadera esclavitud"

(Ernesto SABATO).

Hablar de la tecnología es hablar de uno de los temas de nuestro tiempo: la tecnología hoy impera; todo tipo de máquinas elaboradas por el hombre 
facilitan la existencia humana; el hombre, que tiende al menor esfuerzo (según nos lo dicen las ciencias actuales del cerebro humano), encuentra en la tecnología un aliado; el hombre crea la tecnología por la facilidad que ella le trae para su quehacer cotidiano.

Así, la tecnología es útil, buena, facilitadora.

No obstante, como toda creación humana, la tecnología trae interrogantes éticos; junto a sus ventajas también cabe entrever riesgos.

Tales riesgos son susceptibles de reflexión máxime si el abuso de la tecnología no facilita la posibilidad de pensar y de pensar correctamente.

En esa línea encontramos voces de alarma frente al exceso de la tecnología, como el arriba nombrado Ernesto SÁBATO (especialmente en sus obras: "Hombres y engranajes", y, "La resistencia"), y, Giovanni SARTORI, pensadores que merecen gran crédito.

Este último en concreto habla del desplazamiento del "homo sapiens" por el "homo videns" por obra de la tecnología idolatrada.

Todos pueden ser, por obra de las facilidades que ofrece la tecnología, paradójicamente presa de ella, condiciona, ata, esclaviza, aliena como seres pensantes, no facilita el filosofar.

Sabemos por propia experiencia y por simple observación cómo absorben la televisión, el internet, las redes sociales, los aparatos de todo tipo, cada vez más frecuentes y sofisticados; queremos tener la última información por un lado, y el último adminículo tecnológico, por el otro.

Creo que ello ha traído, además de la merma del pensar, la quita del lenguaje escrito y oral.

Hay aparatos que acercan a los lejanos (Skype) -y eso está bien-, pero alejan a los cercanos (TV, celular) en las reuniones sociales, y eso no parece humano.

¿Aparato y pensamiento se alejan? Parece que sí.

Se observa que la inmensa mayoría de la gente vive encableada, con audífonos, que llevan a sólo oír; muchos tienen las manos ocupadas, rehenes, cautivas, en los celulares, I pods, etc.

Así, los sentidos -aunque ellos ciertamente son puertas que abren al conocimiento y a la reflexión-, terminan encerrados en sí mismos, sin apertura al pensamiento. 
Desde luego el hombre no puede dejar de pensar (salvo cuando duerme) pero parece que hoy, por obra de la tecnología, esa capacidad está al menos bastante reducida. Y si ello es así, la filosofía por ende se resiente.

Por eso, hablar de este tema de la tecnología idolatrada es hablar de un condicionante negativo de la filosofía: he ahí su importancia. Y concretamente para la iusfilosofía, pues el derecho se queda en el derecho puesto, sin profundizar en sus raíces, en sus orígenes, en sus causas, y en sus consecuencias.

La filosofía, por el contrario al encerramiento de los sentidos, a pesar de que parte de ellos, es actividad del pensar, del meditar, del elevarse sobre los sentidos aunque sin ir en su contra pero sí superándolos; si nos quedáramos en los solos sentidos no nos diferenciaríamos de nuestros hermanos animales; la filosofía es pensar por el gran gusto de pensar, a solas ( $\sin$ mucho apego a lo sensual), con distancia respecto a tiempo y espacio (sin renunciar a ellos).

De esta manera podemos ir diciendo que la tecnología facilita el actuar humano, pero, al mismo tiempo, aleja en gran medida del pensar filosófico pues éste es dificultoso, contrario al facilismo tecnológico, al quietismo tecnológico, al sedentarismo tecnológico, y es por ello que tienden a enfrentarse, y por lo que hay que tratarla -a la tecnología-con gran prudencia $\mathrm{y}$ distancia.

De hecho, vemos a muchísimos seres humanos con aparatos y a poquísimos hombres y mujeres dedicados a filosofar; lo imperante hoy son los aparatos, las máquinas, y lo extraño es la filosofía.

¿Qué hacer, pues? Se trata de reaccionar humanamente, éticamente, prudencialmente, sin demeritar la tecnología pero sí cuestionándola con actitudes éticas; corresponde emprender un esfuerzo de lograr una cierta distancia entre tecnología y filosofía.

Si se trata de rescatar a la alicaída filosofía, camino posible sería reducir inteligentemente a la tecnología, dedicarle menos tiempo, sabiendo que su uso muchas veces no es más que una adicción -por favor, no nos digamos mentiras con eufemismos frente a ella-, y, esforzarse en dedicar más espacios de tiempo al solo pensar, al deleite de pensar (aunque con cierto esfuerzo), de meditar, de introducirse en sí mismo, de considerar el mundo circundante, de no ser seres que pasamos por la tierra sin interrogarnos nada, y de considerar, por supuesto, las ventajas, peligros y consecuencias de la tecnología. 
E. TOLERANCIA Y DIÁLOGO: CONDICIONES PARA FILOSOFAR EN DERECHO

"Si, mediante una palabra lo más aproximada posible, quisiéramos indicar el sentido de este carácter esencial del derecho de los Estados constitucionales actuales, quizás podríamos usar la imagen de la ductilidad"

(Gustavo ZAGREBELSKY).

De entrada digamos que la tolerancia y el diálogo constituyen hoy valores apetecidos, cosa con la que comulgo, y estoy seguro que todos comulgamos, dentro de ciertos límites razonables. Creo y creemos que ambas cosas con indispensables para vivir en comunidad; sin ellos imperaría el odio, la ruptura, la insolidaridad, la incomunicación; tolerancia y diálogo son objeto de loa para pensadores como Zagrebelsky, Amartya, Kaufmann, por nombrar algunos.

El primero, Zagrebelsky, dice que el derecho constitucional actual tiene dos claves: "el pluralismo de valores" y "la lealtad en el enfrentamiento" (2005, pp. 14-15); podemos traducir -si se quiere un poco voluntariosamente de nuestra parte- "lealtad en el enfrentamiento" precisamente por "tolerancia".

Sen en su obra "La idea de la justicia" también repite como una de sus claves el "espíritu abierto", la "imparcialidad", como sinónimos de "tolerancia", también voluntariosamente de mi parte, aunque no creo que ello sea un exabrupto mío.

Kaufmann por su parte en su libro "Filosofía del derecho" encabeza sus reflexiones con esta frase: "Imperativo categórico de la tolerancia: Actúa de tal manera que las consecuencias de tu acción sean compatibles con la mayor posibilidad de evitar o disminuir la miseria humana" (Kaufmann, 2002a, p. 27). Tolerancia, entonces, es sinónimo de democracia constitucional, de camino para la justicia, y, de evitación o disminución de la miseria humana.

Ahora bien, el tema de la tolerancia es antiguo. San Pablo en el siglo I habla de ella con ese término preciso en el terreno estrictamente moral y espiritual para las primeras comunidades cristianas. Más tarde, el emperador Galerio en el siglo IV estableció mediante decreto la tolerancia de los cristianos (posteriormente el Edicto de Milán acabó con la persecución a los cristianos, y tiempo después el cristianismo por decreto de Teodosio el Grande, estableció el cristianismo como religión oficial del Imperio Romano). Y en tiempos de la Modernidad (siglos XVII y XVIII) existieron dos paradigmas en la 
materia: Locke y Voltaire, quienes hablaron expresamente de tolerancia para las religiones católica y protestante entre sí (en época de guerras de religión).

Hoy, la tolerancia se extiende a todos los campos -no sólo al religioso-, y, además, no se reduce a un simple "resistir" al otro distinto sino a reconocerlo integralmente como persona, a ver sus aportes al debate público y jurídico yendo más allá del mero aguantar al diferente, pues éste puede enriquecer el pensamiento.

A pesar del discurso a favor de la tolerancia, y del diálogo, se observa hoy, sin embargo, una gran intolerancia; se predica mucho la tolerancia liberal, cosa que está muy bien, pero, desgraciadamente no se practica; entre el dicho - discurso- y el hecho - praxis- hay mucha distancia; de esa manera, siguiendo a Sen, no puede construirse la justicia -fin del derecho como se verá más adelante-, ni tampoco edificarse la democracia liberal (el mejor caldo de cultivo del derecho).

El laicismo estatal ha sido -creo que deberíamos admitirlo-mal practicado; y así muchos de los autollamados tolerantes liberales no practican la tolerancia; la atmósfera de hoy es que todo es posible, menos no ser de avanzada o progresista, y así, la tolerancia se elimina por incoherente, ya que la avanzada o el progresismo, en una sana dialéctica, necesita de frenos que limiten los desbocamientos; también en esta materia se requiere recurrir al punto medio.

Hay inamovibles éticos y jurídicos como prohibir el uso ilegítimo de las armas, el abuso de niños, de las mujeres, y de los ancianos; creemos que estos ejemplos son convicciones universales; pero, oponerse al aborto, a la eutanasia, o al consumo mínimo de drogas -desde luego racionalmente- no tiene por qué ser tenido como inadmisible en todos los casos; pero, de hecho, resulta inadmisible para ciertos progresistas; ¿por qué restringir el campo de la tolerancia si existen argumentos racionales o razonables aun en esos casos mencionados? ¿No hay que aprender a escuchar argumentos?

Igualmente se observa que se está incluso negando la objeción de conciencia para los funcionarios públicos; lo único que se acepta es la objeción de conciencia de los ciudadanos de a pie; es más, tampoco se admite la objeción de conciencia "institucional" (negada por ejemplo en el fallo sobre el aborto, de la Corte Constitucional colombiana, del año 2006), lo cual tampoco es apertura a la tolerancia y más bien conduce a totalitarismos estatales.

¿El aborto, la eutanasia, o el consumo de drogas, deben generalizarse acríticamente? ¿No es eso uniformar los comportamientos humanos como 
consecuencia de corrientes sociales dominantes? ¿Puede a un funcionario público impedírsele manifestar su discrepancia contra leyes y fallos que van contra su conciencia? ¿No es ello privilegiar al Estado sobre la persona humana? ¿No está el Estado al servicio de la persona humana?

Recientemente Latinoamérica perdió a uno de sus hombres más célebres, en diciembre de 2012, Oscar Niemeyer, arquitecto brasileño; en una entrevista aparecida en el Canal Teleamiga, a propósito de cuando Niemeyer cumplió cien años de edad, decía este gran hombre que lamentaba tantas arrogancias del poder político cuando realmente lo importante en la vida es la vida misma y la solidaridad humana: son ideas para tener en cuenta en esta época de tanta injerencia del Estado y de cultura de la muerte. Son voces para oír dentro de una cultura de tolerancia y diálogo. 



\section{HISTORIA DE LA IUSFILOSOFÍA}

"La libertad del hombre, esencia de su historicidad, tiene aspectos terribles. Por dominar el tiempo y el instinto, el ser humano puede penetrar con su apetito en los sistemas ecológicos y destruirlos. También puede repararlos. La elección entre dos posibles acciones, una consumidora y destructora, la otra conservadora y fecundante, pertenece en él al campo de las decisiones morales. Es ahí donde

debe cargarse el acento"

(Luis Suárez)

Un libro como este busca en el fondo entender qué es la filosofía del derecho. Para ello he echado mano antes en el capítulo anterior del examen de su misión. En seguida trataré de seguir en la misma tarea, esto es, entender qué es la filosofía del derecho pero ahora recurriendo a su historia; ella es una herramienta muy importante para conocer sus principales ejes temáticos.

La filosofía del derecho, como tal expresión, es relativamente reciente: se remonta al año de 1797 cuando Gustavo Hugo la utilizó por primera vez en su libro "Tratado de Derecho Natural o Filosofía del Derecho" (Noguera, 1997a, pp. 35 y ss).

Ahora bien, podemos hacernos esta pregunta: ¿antes de esa fecha -1797se "hizo" filosofía del derecho, aunque sin ese nombre? Creemos que sí.

En efecto, Aristóteles no habla nunca de filosofía del derecho; trata sí del derecho natural y del derecho legal, en el capítulo de la "justicia", en su obra "Ética a Nicómaco" (por "justicia” léase "derecho", ya que la justicia era el nombre que se le daba a lo que después se conoció con el nombre de derecho). Otro tanto sucede, por ejemplo, con Tomás de Aquino y su "Tratado sobre la justicia", el cual tampoco expresamente habla de filosofía del derecho sino que se enmarca en el puro derecho natural y el derecho positivo (como apoyo y desarrollo del natural). Y lo mismo dígase del iuisnaturalismo propio de la Modernidad racionalista en los siglos XVII y XVIII, tiempo hasta el cual se habló de "Ciencia del Derecho Natural" y que fue reemplazada luego por 
el nombre de filosofía del derecho a partir del mencionado Gustavo Hugo (Noguera, 1997b).

Ahora bien, es importante señalar que en la época de Gustavo Hugo, la filosofía del derecho empieza a tener un cierto sabor positivista (ya no de derecho natural). He ahí la diferencia entre la filosofía del derecho y la ciencia del derecho natural anterior a aquélla: antes de Gustavo Hugo se hacía filosofía del derecho, aunque sin esa denominación, pero con una muy clara circunscripción al derecho natural; después de Hugo, la filosofía del derecho empieza a tener un mayor carácter "idealista", como era lo propio por la influencia kantiana, fenómeno que se fue acrecentando en el siglo XIX, que siguió siendo, y más todavía, enteramente idealista (por ejemplo con el idealismo alemán).

Repitámoslo: tratar de la historia de la filosofía del derecho es un capítulo de la iusfilosofía muy interesante pues nos ayuda a ilustrar los primeros debates de ésta (los podemos llamar ejes temáticos), los cuales no han dejado de preocupar a los iusfilósofos hasta hoy.

Se puede decir que esos debates, esto es, los enfrentamientos entre los defensores del derecho natural, en su versión clásica, y en su versión Moderna llamada iusnaturalista, entre sí, o los debates entre los defensores del derecho natural y el iuspositivismo, siguen estando vivos; claro está que estos debates han encontrado a su turno un cierto apaciguamiento con la "tercera vía iusfilosófica", que veremos un poco más adelante siguiendo la cronología histórica de la iusfilosofía.

Debe advertirse, que los temas más interesantes para el mundo del hoy se dan con las nuevas posiciones iusfilosóficas (especialmente la tercera vía mencionada); al fin y al cabo lo actual, siempre presenta una atracción especial para el ser humano; pero ello no debe llevar a olvidar la "tradición" iusfilosófica, pues ella sirve siempre de punto de referencia ineludible; de toda esta tradición nos ocuparemos a continuación hasta llegar al presente.

A.

\section{EL DERECHO NATURAL}

Empecemos por resaltar un común denominador de las distintas escuelas del derecho natural:

La escuela del derecho natural -más comúnmente llamada “iusnaturalismo", aunque impropiamente pues éste es sólo la denominación que se dio al derecho natural racionalista en la época de la Modernidad- tiene por clave el descubrir - no inventar- un derecho (por ahora digamos así: un derecho, 
sin más, como mero fenómeno), anclado en la naturaleza humana; de otra parte, dice esta escuela, el derecho positivo es su explicitación y concreción, y no puede contradecir al derecho natural que es su fundamento; desde la naturaleza humana existe el referente primero y necesario del derecho; la naturaleza humana da "validez" intrínseca al derecho positivo; esa naturaleza humana es dada, determinante, no determinable, no creada por el hombre, $\mathrm{y}$, desde ella, se construye, a su turno el derecho positivo, que no puede contradecir al derecho natural, que es su matríz.

Arthur Kaufmann, por citar sólo un autor, dice que la característica más sobresaliente de la escuela del derecho natural es la "indisponibilidad" del derecho en su creación y desarrollo ya que éste tiene por límites los fijados por la naturaleza del hombre (Kaufmann, 2002b, p. 63).

Dicho lo anterior veamos algunas de las sub-escuelas más representativas de la escuela del derecho natural.

1.- En tiempos remotos, más que un derecho natural raizal o autónomamente humano, existió un derecho prescrito por la divinidad a los hombres (Sancho, Izquierdo \& Hervada, 1981, p. 64), aunque con tintes de derecho natural, dado que en todos los documentos y manifestaciones como orden normativo jurídico dado por la divinidad a los hombres existen mandatos comunes: no matar, no robar, no defraudar, etc.

Sancho Izquierdo y Hervada hablando de esta sub-escuela la ubican más exactamente como "precedentes" del derecho natural; pero podríamos llamarlo también derecho natural primitivo; fue algo así como un "iluminismo jurídico" (para tomar una expresión de San Agustín); sabemos que posteriormente, con Aristóteles en el s. IV aC, y luego con Santo Tomás de Aquino en el siglo XIII, se va a dar un derecho naturalmente humano, derecho autónomo, aunque dirigido en última instancia por Dios.

Veamos de manera muy sucinta el derecho mencionado, el dado directamente por Dios a los hombres:

Remontándonos al Código de Hammurabí, antiquísimo (2123-2080 a. de C.), vemos que el dios sol, Schamasch, le entrega al rey Hammurabí, un "derecho superior" al mismo rey para procurar la justicia de su pueblo; otro tanto sucedió con el Libro de los muertos en Egipto, orden dado por los dioses para entrar en el reino de Osiris y Maat, donde se consagra el rechazo del fraude, de la mentira, del asesinato... Lo mismo dígase de las Leyes de Manú en la India, donde también se consagra una ley natural, y, en la China, 
con el Tao como orden universal; pero el más representativo para Occidente de todos esos órdenes divino-naturales es el de los diez mandamientos -el Decálogo-dados por Yavé a Moisés; del Decálogo dicen Sancho Izquierdo \& Hervada (1981, p. 67):: "En él ha visto la tradición iusnaturalista uno de los lugares (loci) donde se encuentran recogidos del modo más pleno las bases, los principios y las reglas de derecho natural".

Reliquia de ese derecho natural directamente proveniente bien sea de las divinidades paganas, o bien de la divinidad monoteísta, es la referencia a Dios como fuente del derecho, $\mathrm{o}$, al menos como alguien a quien invocar para pedir ayuda para conseguir los fines que se propone el texto constitucional o legal.

Así, en los Preámbulos constitucionales, sobre todo, latinoamericanos, se encuentra esa referencia a lo divino: “...el Constituyente invoca la protección de Dios, lo que es muy común en el constitucionalismo latinoamericano. No así en Europa, donde, de treinta y cinco Constituciones que hemos revisado, apenas cinco contienen alguna alusión a lo sobrenatural en el Preámbulo... El integrante de la Asamblea, Alberto Zalamea, en su ponencia a la Comisión sobre 'Preámbulo y principios', explicó que se invocaba la protección de Dios 'sin pretender asumir su vocería, pero recordándolo, sí, como fundamento de la dignidad humana y fuente de vida y autoridad para el bien común" (Albendea, Pabón, 1994, pp. 14-15).

La referencia a Dios por el ordenamiento jurídico, es propia de países con raigambre religiosa mayoritaria; ahí se observa a las claras el referente de Dios en el orden jurídico, sin que ello indique la abolición de la libertad religiosa (aunque se debe reconocer que hay excepciones).

2.- Nada más lógico que hablar de un derecho natural en la antigüedad (Grecia, Roma, y Edad Media), cuando la "naturaleza física" poseía tanto valor para el hombre, pues dicha naturaleza o ley natural es fuente del derecho humano para esta escuela.

A veces, ciertas culturas, como las indígenas en Latinoamérica, adoraban a la naturaleza; en ella veían al mismo Dios. Y esa naturaleza se trasladaba de contera a toda la realidad humana, incluida el derecho: la mitología estaba fuertemente enraizada en la naturaleza, había dioses para todos los fenómenos naturales: cosechas, mares...(animismo); la misma filosofía era "naturalista" al comienzo (sin dejar por ello de tener su nota metafísica): el "ser", el centro de atención de la filosofía en cuanto se pregunta qué da consistencia a todo lo que vemos, pues ella se preguntó desde el comienzo 
acerca de qué da consistencia a todo, que es para esa filosofía de los inicios, el agua, el fuego, la tierra.

¿Por qué no, entonces, en el hombre mismo habría de desconocerse un derecho anclado en la naturaleza en un principio puramente física, cosmológica? Si el hombre es "humus", es decir, tierra y por lo tanto naturaleza, ella tiene por lógica su expresión en el derecho: las normas que se llaman jurídicas, los códigos jurídicos, las costumbres jurídicas, los vínculos jurídicos que obligan dentro de la sociedad, tienen una fuerte raigambre natural, tal como se consagra en el derecho a la vida física, en el derecho a la tierra...: a eso se le llamó "derecho natural", que pasará de la ley del más fuerte -eso era lo tenido por natural al principio-, a la ley de la igualdad de naturaleza humana: por eso no era descalificada la esclavitud al comienzo, pero ella se irá superando con el tiempo por el deseo de igualdad general.

Veamos a continuación a unos cuantos de los autores quizá más representativos (sin que por ello agotemos su elenco) que hablan del derecho natural en la antigüedad griega, romana y medieval:

2.1.- En Grecia antigua el derecho natural encuentra su expresión máxima en Aristóteles (IV a. de C.), quien afirma: "De lo justo político una parte es natural, otra legal. Natural es lo que en todas partes tiene la misma fuerza y no depende de nuestra aprobación o desaprobación..." (Aristóteles, 1981, p. 66).

Esa frase es emblemática para el derecho natural. Quedó consignada allí la idea precisa del derecho natural: no es la ley del más fuerte como se pensó al principio, es, por el contrario, una "ley general", universal, la que tiene una misma fuerza en todas partes (esa misma concepción la tuvo la ONU en 1948 cuando hace la "Declaración universal" de los derechos humanos, no será una declaración para Occidente, ni para Oriente, sino "universal"); además es un derecho objetivo, superador del subjetivismo individual o del facultismo (para quien lo primero en el derecho es la facultad), y por eso no depende de nuestra aprobación o desaprobación: es así la encarnación del más típico "realismo jurídico".

El realismo filosófico es precisamente el basarse en la "cosa exterior" al "pensamiento"; es partir de las cosas visibles para llegar a las invisibles, es la metafísica original y siempre distintiva de la filosofía original; la cosa es "en sí misma"; la cosa, el derecho, no es lo que "yo crea que es" en mi pensamiento, sino que es lo que es en sí, y no en mí; no es el derecho subjetivo o facultad personal lo que prima; por el contrario, el intelecto humano sale a apresar 
las cosas, y el derecho entre ellas como garantía de la convivencia: todos saben a qué punto referencial atenerse (por el contrario, hoy, la aprobación o desaprobación de las cosas, y del derecho, depende de las mayorías sociales o parlamentarias, quedando de esa manera el derecho al vaivén de los tiempos y las épocas; en otras palabras, es el sociologismo en toda su expresión; pues bien, así no pensaba Aristóteles; para el estagirita el derecho es "objetivo", aunque admite una cierta flexibilidad por medio de la equidad).

2.2.- En Roma antigua, por ejemplo Cicerón (ss. II-I), también habla de un derecho natural; Cicerón "... busca la misma esencia del derecho y dice que tiene que ser buscada en la naturaleza del hombre" (Beuchot, 2006, p. 29).

Vemos en Cicerón un aporte nuevo: el derecho natural es equivalente a naturaleza del hombre; este concepto de derecho natural anclado en la naturaleza del hombre es uno de los pilares del derecho natural de todos los tiempos. Si en Aristóteles la nota del derecho natural es lo universal, la característica Cicerón es la naturaleza humana.

2.3.- Tomás de Aquino (s. XIII) también habla de derecho natural, así: "Como hemos dicho, el derecho o lo justo es aquello que se ejecuta por otro según una cierta norma de equidad. Y algo puede ser adecuado al hombre de dos maneras: primera por la naturaleza misma de la cosa; por ejemplo, cuando alguien entrega algo con el fin de obtener otra cosa equivalente, y entonces se llama 'derecho natural'. Segunda, cuando una cosa es adecuada o equivalente a otra por un mutuo acuerdo o por contrato, como cuando alguien manifiesta que estaría contento con recibir tanto más cuanto. Y esto puede hacerse de dos modos: primero cuando se hace por acuerdo privado; y segundo, por ley pública como cuando todo el pueblo está de acuerdo en que tal cosa sea equivalente a otra; o bien cuando lo ordena el gobernante que dirige los destinos del pueblo y lo representa. Y en este último caso se llama 'derecho positivo"' (de Aquino, Tomás, Tratado de la justicia, 1998, artículo 2).

Vemos en Aquinas una idea central del derecho natural que en realidad de verdad se inspira en Aristóteles: pero, ya no es tanto la idea de aquello que tiene la misma fuerza en todas partes (universalidad) y que no depende de la aprobación o desaprobación individual o subjetiva; tampoco habla de la naturaleza humana (aunque ciertamente Aquinas trata al hablar del derecho natural de las "tendencias naturales" del hombre, a saber: conservación de la vida; propagación de la especie; amistad y asociación; y búsqueda de la verdad y ante todo de la verdad sobre Dios), sino que se centra en la "naturaleza misma de la cosa", pero entendiendo por ella una "equivalencia". 
Esa palabra, es decir, "equivalencia", da a entender para el aquinate un valor similar, no exacto, no siempre el mismo e igual matemáticamente, sino aproximativo o geométrico, lo cual da a entender de paso dinamicidad e historicidad del derecho natural; esa ductilidad del concepto del derecho natural es una de las notas más apreciadas a lo largo de los tiempos en Tomás de Aquino; así lo resaltan por ejemplo Sancho Izquierdo y Hervada, al decir: "Sin embargo, Tomás de Aquino no se limita al simple enunciado de la inmutabilidad, sino...que la sometió a examen, reduciendo a dos las posibles causas de mutación de la ley natural...: o por adición..., o por sustracción... Santo Tomás entiende que no cabe mutación de la ley natural por sustracción... Que la adición de reglas de ley positiva puede suponer algún cambio en la ley natural es un hecho de experiencia" (1981a, pp. 204-205).

Resumamos los tres pilares de la Escuela del Derecho Natural "clásico" Griego, Romano, y Medieval (también llamado "aristotélico-tomista) (1981b, p. 300).

a) El derecho natural se enraíza en un universal (la naturaleza humana) independiente del yo (Aristóteles; Cicerón, Tomás de Aquino); b) el derecho natural es también la misma naturaleza de la cosa pero en algunos casos como equivalencia (Tomás de Aquino).

Esos pilares deben tenerse siempre en cuenta a la hora de entender el derecho natural clásico; podríamos expresarlos también más simplemente así: universalidad, naturaleza humana, equivalencia. Si el derecho, cualquier derecho, tiene en cuenta esas cualidades, estaremos hablando de derecho natural; por ejemplo, cuando hoy en día se habla de "delitos de lesa humanidad", se habla entonces de algún modo de derecho natural; o cuando se recurre a la equivalencia, a la equidad en la aplicación del derecho, se está hablando también en cierta forma de derecho natural; o cuando se defiende la naturaleza humana, vgr., afirmar que el matrimonio es para heterosexuales, en tal caso igualmente se habla de alguna manera de derecho natural.

Las aplicaciones del derecho natural en la actualidad también las vemos por ejemplo cuando se habla de si hay un derecho universal válido tanto en Occidente como en Oriente (D'Agostino, 2007, pp. 245 y ss.); este autor habla de algunos "rasgos" universales del derecho tales como la universal prohibición del incesto, el rechazo también universal del canibalismo, o la norma universal de la reciprocidad); o como cuando se entra a formular una especie de "ética universal" (Hans, Kûng \& Kuschel, 1994), intentos ambos 
de reformular o actualizar un derecho natural universal, anclado en la común naturaleza humana.

Demos una puntada más sobre el tema espinoso y difícil de la naturaleza humana; al campo del Derecho Natural clásico que venimos tratando, se ha sumado tradicionalmente la Iglesia Católica; para la Iglesia Católica existe una naturaleza humana común: dice la Iglesia que esta naturaleza quedó caída con el pecado original, y, por haber caído en el pecado, necesita de la Gracia Divina alcanzada por Jesucristo, aunque la naturaleza no quedó destruida por el pecado original; todos los santos han hablado de malas inclinaciones de la naturaleza que hay que combatir; y en consonancia con esa postura, aunque no idéntica por supuesto, se encuentran los escritos de pensadores y filósofos que hablan de la necesidad de la virtud, de la llamada "vida buena".

Pero otra noción, diferente a la anterior, afirma que dicha naturaleza es en general buena.

Así el panorama, la línea divisoria, aun en el mismo campo del derecho natural, es difícil, pues habría una naturaleza humana caída y otra naturaleza humana buena per se.

Como no todos comparten la creencia católica ni la ética de la virtud, puesto que se ha entrado desde hace un tiempo de lleno en el llamado "pluralismo cultural", ético y de religiones, la ética, así como el derecho, han adoptado por necesidad de "convivencia" (la convivencia pasa a un primer plano entre los valores de la humanidad), la línea de la laicidad, de la neutralidad pública (a la que no se debería impedir que todos desde sus creencias y éticas se expresen a fin de "elevar el tono" humano de la sociedad, tal como por ejemplo Michael Sandel y en general los llamados "comunitaristas" sostienen), lo cual se concreta en lo que se ha denominado la "ética de mínimos", esto es, que ninguna religión ni ética de lo bueno se puede considerar que es la "única" en el mundo de la ética, y del derecho; las éticas religiosas serían las "éticas, y derechos, de máximos", que no deben ser obstaculizadas en su diálogo público, pero que a lo sumo pueden alcanzar solo el nivel del "testimonio de vida".

Por ese camino se debe llegar a una "ética de mínimos"; ella sería, ahí sí, la única ética, y el único derecho, en aras, como se acaba de decir, de la paz y la convivencia.

Pero... ¿cuáles son esos mínimos éticos? Adela Cortina nos dice que son los valores de libertad, igualdad y solidaridad; los derechos humanos; la tolerancia activa; y el ethos del diálogo (2000, pp. 38 - 42). 
Ahora bien, cabe ante lo anterior hacerse varias preguntas: ¿de qué libertad hablamos? ¿De una libertad absoluta o de una libertad con ciertos límites? ¿De una libertad con contenido o de un simple derecho a elegir lo que sea? Y otro tanto cabe decir de la igualdad: ¿se trata de una igualdad absoluta o de una con ciertas jerarquías? ¿No habla el mismo ordenamiento de que existen normas superiores, estableciendo, así, una jerarquía de ellas? ¿No habla el ordenamiento jurídico de que los derechos de los niños prevalecen sobre los de los demás?

Quizá el valor de la solidaridad, y por qué no decirlo también, del medio ambiente, sean valores absolutos; ante ellos no cabrían restricciones.

Ahora, hablando de derechos humanos, los basados en la libertad y la igualdad, vuelven a surgir interrogantes del estilo de los ya planteados por Michael Sandel: "no basta" la "mera elección liberal" sino que es menester echar mano de las "discusiones morales" que subyacen en las elecciones que se toman.

Y tratándose de la tolerancia activa y del diálogo cuánto pueden ayudar las reservas morales de las personas -las virtudes personales- para hacer realidad dichas tolerancia y diálogo.

3.- El iusnaturalismo de la Modernidad racionalista (ss. XVII y XVIII) introdujo al trípode clásico visto (esto es, derecho natural universal, naturaleza humana, y equidad), cambios sustanciales. Veamos:

Detrás del iusnaturalismo de la Modernidad estuvo como telón de fondo crear el Estado; y el Estado (si es democrático) se edifica sobre el Parlamento y con él, nace el derecho positivo, obviamente de carácter estatal; no obstante, algo del derecho natural quedaba en pie, y por eso se habla aún de iusnaturalismo: sí, existe el derecho natural, aunque circunscrito, con Hobbes, al derecho a conservar la vida; y, con John Locke, se sigue hablando de derecho natural pero circunscrito al derecho a la propiedad en tres dimensiones: derecho a la vida-tal como Hobbes-, derecho a la libertad, y derecho a las posesiones. Incluso Rousseau sigue hablando de derecho natural (y, aclaremos para aclarar: no es que antes de estos tres pensadores se hablara de derechos humanos, no, éstos empezarán a formularse un poco de tiempo después, con las "declaraciones" de derechos humanos democráticas).

Pero, como se trataba de edificar el Estado tal como dijimos, el tema del "contrato social" atrapa ahora casi toda la atención, tanto para edificar al Estado, como para edificar el derecho; dicho contrato era el artificio 
racionalista para construir el Estado y el derecho (esto sucedió tiempo después de la etapa histórica del feudalismo medieval, y de los nuevos imperios de finales de la Edad Media, especialmente el de Carlos V, cristiano católico. Con ello ya se puede intuir que detrás de estas concepciones jurídicas existen dos escuelas enfrentadas: una medieval cristiana-católica, y otras de carácter laica).

El Estado quería nacer en esta etapa de la historia sobre bases filosóficas racionalistas y casi todas protestantes: Francia, Holanda, Inglaterra, Italia, se construyen a partir de Hobbes, Locke, Rousseau... Sólo España edifica el Estado y el Derecho sobre bases políticas y jurídicas de raíz escolástica, católica, de Escuela de Derecho Natural Clásico aristotélico-tomista.

De esta manera, se perfila, se repite, una división notoria entre el Estado y el Derecho cristiano católico y el Estado y el Derecho protestante y laico; se empieza así a dar la confrontación inevitable con trasfondo religioso entre la escuela del Derecho natural y la escuela del iuspositivismo.

En el origen de esa confrontación se encuentran el protestantismo político, y, el racionalismo filosófico, que llevará a distintas y opuestas concepciones de Estados, así como a una pugna en materia religiosa y de sistemas filosóficos y jurídicos, que habrá de durar por varios siglos, y que pensamos, sigue en pie hoy en buena medida.

Ahora bien, debe decirse con claridad que, en materia de Declaraciones de derechos humanos, éstas son todavía muy similares en dicha época de comienzos de la Modernidad, a uno y otro bando político, religioso, filosófico y jurídico.

En efecto, si se observan sin mucho esfuerzo esas Declaraciones de derechos, todas ellas tienen en común comenzar por la invocación a Dios y la sacralidad de esos derechos como naturales a todos los hombres.

Empero, con el pasar del tiempo, sobre todo al llegar al siglo XIX, el iuspositivismo ganará casi todo el terreno frente a las toldas católicas; a ello contribuyó en buena medida en ese siglo el fenómeno de la Codificación Jurídica, cuyo máximo exponente será el Código Civil de Napoleón, de 1804 (y, oh, paradoja, la misma Iglesia Católica será codificadora de su derecho mediante el Codex Iuris canonici de 1917 aunque sin renunciar al derecho natural).

Con la caída del totalitarismo político hitleriano a mediados del siglo XX, el legalismo o iuspositivismo kelseniano entra a su turno, en crisis, y empieza a abrirse paso poco a poco, con Gustav Radbruch, la denominada Tercera vía iusfilosófica (que veremos más adelante). 
Ésta vía buscará alejarse de los dogmatismos jurídicos: ya no un derecho natural estático (propio del iusnaturalismo racionalista de la Modernidad. Por el contrario, la Escuela del Derecho Natural clásico nunca predicó el pasivismo, el quietismo, la petrificación del derecho, pues como hemos visto atrás, siempre habló de un derecho natural elástico, equitativo, siguiendo la equidad de a Aristóteles y la equivalencia de Aquinas; esa es una de las afirmaciones que deben reivindicarse del derecho natural clásico, so pena de cometer una gran injusticia con él), ni tampoco el dogmatismo del legalismo iuspostivista; la tercera vía iusfilosófica dirá un no rotundo a ambos dogmatismos.

Con la tercera vía iusfilosófica, sólo el "derecho notoriamente injusto" no se considera derecho, y afirmar eso se considera no dogmático; la tercera vía iusfilosófica considera que las posturas anteriores, al anclar el derecho en una naturaleza sustancial (postura del iusnaturalismo moderno) o en la norma jurídica (postura del iuspositivismo), se equivocaron, afirma esta tercera corriente iusfilosófica.

Por obra de esta tercera vía iusfilosófica ha habido un "acercamiento" entre las dos posturas antagónicas tradicionales, esto es, la del derecho natural racionalista moderno y la del iuspositivismo (aunque sigue habiendo puntos en conflicto, tales como el aborto, el matrimonio de homosexuales, los derechos sobre el cuerpo de la mujer, la utilización para investigación de las células madre embrionarias, el consumo mínimo de drogas, la adopción de niños por parejas homosexuales, y, la eutanasia; en todo lo demás, sobre todo en materia de delitos de lesa humanidad, existe un consenso amplio entre la Escuela del Derecho Natural, la escuela iusnaturalista moderna, y el iuspositivismo, propiciado, tal acercamiento, repetimos, por la Tercera vía iusfilosófica).

Cuál sea el alcance, o los resultados previsibles de ese acercamiento, es cosa que nos dirá poco a poco la historia; para ello es muy de desear a mi juicio el echar mano de la que he llamado "cláusula de revisión periódica de leyes y sentencias de gran impacto social”, así como un "diálogo" tolerante, moral, racional, entre las distintas esferas antagonistas.

4.- El renacer del derecho natural clásico se da desde 1891 sobre todo en el seno de la Iglesia Católica mediante una serie de cartas encíclicas de corte social.

En efecto, después del paréntesis iuspositivista del siglo XIX, donde el derecho natural clásico fue reducido a cenizas prácticamente por obra del 
iuspositivismo científico (el iuspositivismo en general se dio primeramente en el campo de la filosofía política), todos los Sumos Pontífices romanos se han pronunciado a favor del derecho natural.

No es que fuera de la Iglesia Católica oficial (los papas) no se haya dado el cultivo del derecho natural; autores laicos como Michel Villey, Javier Hervada, Francesco D’Agostino, y otros muchos más, también lo han cultivado en sus tratados de iusfilosofía; pero a nivel mundial el impacto de la Iglesia Católica a través de los Papas han tenido un eco quizá más profundo que el de dichos laicos. También la Declaración Universal de derechos humanos de la ONU, de 1948, es en gran medida un pronunciamiento de derecho natural, proveniente, desde luego, del mundo laical, que debe tenerse en cuenta en este breve recorrido que va más allá en su impacto universal que los documentos pontificios, aunque éstos hacen parte de un acervo más doctrinal que la mencionada Declaración que es un documento práctico y concreto de carácter vinculante.

¿Cuál ha sido la característica de los documentos pontificios acerca del derecho natural?

Podría decirse que la Iglesia Católica -los Papas- se han pronunciado mediante documentos que hablan puntualmente de derechos naturales en épocas de especial crisis de tales derechos.

Así, vemos en 1891 cómo León XIII con la encíclica social Rerum novarum se pronuncia a favor del derecho natural a la propiedad privada cuando el comunismo hablaba contra ese derecho, al mismo tiempo que hablaba del derecho fundamental al salario justo, a la huelga, y al sindicato, cuando el capitalismo vulneraba de hecho esas posibilidades del trabajador; no es un tratado de derecho natural en general sino un pronunciamiento acerca de derechos naturales en concreto.

En la década de los años 30s del siglo XX cuando el Estado no tenía en cuenta derechos naturales del hombre como la vivienda, la educación, la salud, el papa Pío XI habla de la necesidad de que el Estado intervenga a favor de esos derechos en la encíclica Quadragesimo anno; y cuando el Estado asfixiaba la libertad humana, también Pío XI se pronuncia contra los totalitarismos de Estado, tanto comunista soviético (con la encíclica Divini Redemtoris) como nazi y fascista (con la encíclica Mit brenender sorge), y a favor de la libertad humana como derecho fundamental.

En los años 60s del siglo XX, el papa Juan XXIII, en época de grandes desplazamientos del campesino a la ciudad, se pronuncia a favor de las 
asociaciones de campesinos para mercadear sus productos (con la encíclica Mater et magistra), así como a favor del derecho a la paz (con la encíclica Pacem in terris), cuando el mundo se enzarzaba en la guerra de los misiles nucleares.

En esa misma década de los años 60s, Pablo VI, en momentos de gran desnivelación socio económica mundial, habla de la paz pero pasando a través del desarrollo de todo el hombre y de todos los hombres (con la encíclica Populorum progressio).

En el Pontificado de Juan Pablo II, éste habla a favor del derecho al trabajo digno (con la encíclica Laborem exercens) cuando el mundo capitalista se preocupaba más por las ganancias que por la dignidad del trabajador (la cosa sigue estando igual); a la vida (con la encíclica Evangelium vitae) cuando abundaba el genocidio, el aborto, el secuestro (también la cosa sigue igual); y de todos los derechos humanos llamados sociales (con la encíclica Solicitudu rei socialis).

El papa Benedicto XVI (2005), en el documento probablemente más general -ya no hablando de derechos puntuales como dijimos que caracterizan a todos los anteriores- de toda la doctrina social de la Iglesia, ha trazado las tareas específicas del Estado y de la Iglesia: al primero - dice-le corresponde la justicia, y a la segunda la caridad, sin que por eso se excluyan mutuamente Estado e Iglesia, sino que por el contrario la Iglesia puede mancomunarse con el Estado para el bien del hombre; es momento de diferenciaciones pero también de tareas conjuntas para el bien humano, dice Benedicto XVI.

B.

\section{EL IUSPOSITIVISMO}

Tratemos de mostrar el común denominador del iuspositivismo antes de abordar algunas de sus principales sub-escuelas.

El iuspositivismo se caracteriza por partir de un solo rasgo de la naturaleza humana -ya no la completa naturaleza humana como predica la escuela del derecho natural, naturaleza humana compuesta de cuerpo y de espíritu-; el sólo rasgo humano que se absolutiza es la razón del hombre, bien sea del Legislador, o también de la sociedad, o de la autonomía absoluta o casi absoluta del individuo.

Sigamos en este punto a Arthur Kaufmann; dice que la característica del iuspositivismo es la "libre disponibilidad" del derecho (2002a, p. 63); no es la naturaleza humana dual -cuerpo y alma-su punto de referencia, sino la naturaleza humana en cuanto a la sola razón humana (2002b, p. 79). Es una 
creencia total en la razón (y a veces la voluntad humana), tal como lo planteó el racionalismo de Descartes con su "Cogito ergo sum", pienso luego soy, y no, soy, luego pienso.

Fue una toma de conciencia profunda en la razón. Antes (escuela del derecho natural) la razón tenía importancia en tanto en cuanto venerara a la realidad exterior de la cual dependía; ahora, el eje del hombre gira en torno a la sola razón. ¿Esto es válido? Sí, en cuanto que el hombre como animal racional debe valorar dicha racionalidad que lo caracteriza; pero no es válido racionalmente en la medida que puede dejar a sus espaldas la realidad que lo circunda, sólo por no tomar conciencia (no pensarla) de ella en los aspectos que la desbordan o no le interesa conocer; pero tampoco es válido el racionalismo, moralmente, en la medida que lo que no se piense pragmáticamente, existencialmente, no se valora (piénsese no más en el otro hombre), o en pensarlo a la manera propia del que lo piensa y no en la realidad tal cual del otro (lo que genera un individualismo muy acentuado) cayendo en el extremo de querer hacerlo a su manera propia.

Dicho lo anterior entremos a ver sumariamente algunas de las principales escuelas del iuspositivismo:

1.- Como se anotó atrás, el iuspositivismo nació con la "filosofía política" de Hobbes, Locke, Rousseau, Kant; la "teoría del contrato social" de esos autores -sin desconocer un "mínimum" (muy reducido) de derecho natural-, llevó paulatinamente a centrarse en el derecho producido por el mencionado contrato social, fundamentalmente a través del Parlamento.

La teoría del contrato social fue una construcción teórica, racional, del puro pensamiento, como no lo podía ser menos, dado que estamos en pleno apogeo del "racionalismo filosófico", nacido de René Descartes poco antes de esos pensadores mencionados.

Si hasta Descartes la filosofía política era realista, fundada en la "naturaleza social" del hombre (Aristóteles, Cicerón, Tomás de Aquino...), ahora, con los filósofos racionalistas (Hobbes, Locke, Rousseau, Kant...), la política - pero también el derecho-, se construyen sobre una "creación" del pensamiento; ya no es un "descubrimiento" desde el pensamiento, de la realidad que lo antecede, sino que el contrato social "crea" la política y el derecho; todo se realiza mediante una ficción racional, una imaginación racional, un artificio racional.

Ese artificio racional dio resultados: hacer reposar el Estado en el Monarca absoluto (Hobbes), o en el Parlamento (Locke), y donde habría de recaer 
ahora la atención el derecho. Claro está que estos pensadores aún conservan una reliquia del derecho natural, como ya dijimos: el derecho a la vida como derecho natural, según Hobbes, y el derecho de propiedad (aunque con tres expresiones: las posesiones, la vida y la libertad), según Locke.

Y en línea de Hobbes y Locke, las "Declaraciones de derechos del hombre", de los siglos XVII y XVIII (Bill of rights, del siglo XVII, la Declaración de derechos del hombre y del ciudadano, del siglo XVIII), también conservan aún un sabor de derecho natural, incluso primitivo: los derechos del hombre, la vida, la libertad, la propiedad..., que se anclan en Dios; ¡ existen todavía allí reminiscencias del derecho natural primitivo! Y es lo que sigue ocurriendo ante todo en las Constituciones latinoamericanas, en las cuales en sus Preámbulos, se hace una invocación a Dios como Soberano Supremo sobrenatural al que se acude en busca de protección. También en las pequeñas y grandes "codificaciones jurídicas" de finales del siglo XVIII y principios del siglo XIX, se observa una raíz aún en el derecho natural clásico: por eso se dice que cuando se den las llamadas "lagunas de la ley" debe acudirse al derecho natural como fuente que ilumina la interpretación de las lagunas de la ley.

Pero como era apenas previsible, el centro de atención se iba a desplazar poco a poco hacia el "puro" derecho positivo, hacia un derecho positivo a ultranza, hacia el iuspositivismo, aupado después por otros factores: el naciente ateísmo (de los "socialistas utópicos" como Saint-Simón, Proudhon, Owen, Fourier, los marxistas, y algunos liberales), el positivismo científico, el auge de las ciencias naturales... Y así, del inicial positivismo jurídico "moderado" (por ejemplo el del Código de Napoleón de 1804), se va pasando a un positivismo extremo.

2.- El positivismo jurídico empezó en el terreno político como se dijo antes y no en un supuesto derecho natural; y es más, prosiguió en gran medida en ese terreno político: así Hegel, quien centra todo en la "razón" y ésta encarnada dialécticamente en el "Estado histórico", productor único, en última instancia, del derecho.

Marx, ve el derecho como una mera "superestructura", y nunca admite un derecho fundado en el derecho natural, en la naturaleza humana; para Marx lo determinante del derecho son las relaciones económicas de producción (la economía) que es "infraestructura" de la que todo depende.

3.- Nace después el "positivismo jurídico científico"; el siglo XIX es manifestación de éste; el éxito del Código napoleónico una vez comienza 
el siglo XIX (1804), obra excelsa del derecho, llevó a los doctrinantes del derecho a concluir que el derecho se autoabastecía con la pura ley positiva; fue la época de la "exégesis" jurídica, es decir, del apego total a la ley positiva, del seguimiento del tenor literal de la ley sin posibilidades de interpretación más allá de ella; y en consonancia con ese apego estricto a la ley viene Paul Johan Anselm de Feuerbach y su teoría del Estado de derecho positivista: el Estado está sometido al derecho, pero al derecho positivo.

Pero esta época pronto iba a tener sus contradictores; decían que el legislador no era pétreo y debía acomodarse a los tiempos; así, Federico de Savigny, se despega de la pura exégesis, y establece otros criterios de interpretación como la historia de los pueblos: es el nacimiento del "historicismo" interpretativo en el derecho fundamentalmente por medio de la jurisprudencia; aparecen luego otras escuelas iuspositivistas más allá del mero texto legal: el "sociologismo jurídico" (León de Duguit), como derecho nacido de la dinámica social; el derecho como conflicto de intereses particulares, de Von Ihering; el movimiento del derecho libre (Kantorowicz), con un derecho en últimas judicial cuando la ley cae en lagunas; la escuela sociologista, de Max Weber, para quien el derecho es un producto de la cultura cambiante...

Todos los anteriores con cariz "científico" pues tal fue uno de los rasgos "boom" del siglo XIX; ¡ay del que no fuera "hombre de ciencia" en aquél entonces!, cosa que llegará hasta Kelsen quien se declara por sobre todo "hombre de ciencia", del derecho en su caso, ya en la primera mitad del siglo XX (2001, p. 83).

Debe reconocerse que hubo cantidad de aportes valiosos desde la orilla iuspositivista científica; hubo un crecimiento indudable de la ciencia del derecho en muchos aspectos. Déjese dicho. Pero sigamos.

El siglo XX empezó igual que el XIX: iuspositivista, con la figura notable de Hans Kelsen y su "Teoría pura del derecho" (años 30s), intento de demostrar que el derecho no es más que derecho positivo, sin nada que ver con el derecho natural, con la moral, con la política, con la metafísica, con la sociología, derecho que es pura lógica racional del Legislador, que hace la norma voluntarísticamente.

4.- Pero la "experiencia nazi" deplorable por sus violaciones a la persona y sus derechos fundamentales, así como las críticas a Kelsen como jurista 
vacío - cosa que el mismo Kelsen acepta noblemente y lo lleva a admitir un algo de derecho natural, de metafísica, de moral (Kaufmann, 2002a, p. 50 y ss.)-, condujeron al iuspositivismo normativista kelseniano a su agonía y crisis. Viene entonces un renacer del derecho natural como consecuencia lógica ante los estragos del nazismo.

Quedaba de esa manera abierta la posibilidad para que el derecho no se redujera a la sola norma positiva jurídica; el derecho, aunque apoyado en la norma positiva en gran medida, debe mirar otras luces, otros horizontes; ¿cuáles? Los de la eterna búsqueda de la justicia; la justicia debe ser el faro del derecho; el derecho positivo no se autoabastece pues puede resultar injusto.

5.- Sin embargo, después del renacimiento del derecho natural, vinieron otros brotes de positivismo jurídico: lo que Arthur Kaufmann llama "neopositivismo" (2002b, p. 79).

Expositores de él son fundamentalmente: a) Hans Ulrich Evers, para quien lo central o importante del derecho no es la justicia sino la seguridad jurídica, la protección, lo obligatorio, "sin consideración a su contenido"; (2002c, p. $80)$; b) el "funcionalismo" de Niklas Luhmann, para quien igualmente no interesa para nada la idea de justicia sino la de la funcionalidad que reduzca o elimine la complejidad social (2002d, p. 81); c) los teóricos "analíticos": Hart [sobre todo el primer Hart, pues el segundo Hart es un teórico del derecho que acepta un algo de la moral y el derecho natural en el conjunto del derecho positivo, como afirma Beuchot (Beuchot, 2006, pp. 89-90); Ross, Opalek, Peczenik, Aarnio, para quienes el derecho no es más que el análisis riguroso, científico, del "lenguaje", derecho que está separado de la moral, y con separación también de lo empírico respecto de lo normativo (2002e, pp. 85-86).

6.- ¿Dónde ubicar el denominado "neocontractualismo" del siglo XX, el de John Rawls, Jürgen Habermas, y otros, que, como lo dice su misma expresión, es un revivir el contractualismo (social) de Hobbes, Locke, Rousseau, Kant? ¿Es un neoiuspositivismo? Tarea difícil de contestar.

Aparentemente es, en efecto, un iuspositivismo por ser contractualista, sin embargo, dada su remisión a "principios" de claro sabor iusnaturalista, debe ubicarse con mayor precisión en la tercera vía iusfilosófica; por ello, como lo hace Arthur Kaufmann, trataremos esta postura en la tercera vía iusfilosófica que veremos a continuación. 


\section{LA TERCERA VÍA IUSFILOSÓFICA}

Vistas las escuelas del derecho natural, y del iuspositivismo, pasemos a ver en seguida la denominada tercera vía iusfilosófica.

La tercera vía iusfilosófica es paralela a la tercera gran corriente filosófica de la historia: el existencialismo; la primera corriente histórica fue el realismo (ss. VII a. de C., a s. XVII); la segunda el racionalismo (s. XVII a s. XIX), y la tercera el existencialismo (s. XIX hasta hoy); este último nace como reacción frente al idealismo hegeliano, que en su etapa máxima exalta al Estado como un universal total, con riesgo de opacar a la persona humana; tal fue la concepción de Soren Kierkegaard; ahora bien, Kierkegaard no desecha el racionalismo en su totalidad, sólo quiere que la persona humana sea salvaguardada y de ahí su énfasis en la existencia del hombre, es decir, lo que está en la realidad humana junto con la esencia; así, Kierkegaard conjuga ser y existencia.

Dicha existencia subraya varios aspectos: persona humana (personalismo), existencia (existencialismo), vida (vitalismo). De allí parte, aunque debe decirse que una parte del existencialismo se reducirá a lo meramente existencial (existencialismo inmanente), y otra cara del existencialismo dejará en pie su posición original de conjugar esencia y existencia (existencialismo trascendente).

En el campo del derecho era apenas normal que se destacara el aspecto vital del derecho. No son tanto las normas (que desde luego son capitales, pero que en palabras de Alf Ross se consideran derecho estático), sino la vida jurisprudencial del derecho (a este respecto se puede traer a colación unas palabras que lo retratan, de Alvaro D'Ors: el derecho es lo que deciden los jueces).

Entrados ya en materia propiamente de la tercera vía iusfilosófica, es menester decir de entrada que derecho natural y iuspositivismo son la base histórica y conceptual de ésta escuela; por eso las vimos antes como presupuestos necesarios para comprender la primera.

La tercera vía pretende ubicarse entre, o incluso ir más allá a partir de las escuelas del derecho natural y del iuspositivismo (Kaufmann, 2002a, p. 93); ahora bien, empecemos por preguntarnos si esto es posible dadas las "raíces" tan diferentes de una y otra.

En efecto, mientras el derecho natural parte en su discurso de la preexistente naturaleza humana, el iuspositivismo parte de sólo un aspecto de esa naturaleza: la razón y la voluntad humanas, ya no ligadas a la entera naturaleza humana corporo-espiritual (Kaufmann, 2002b, p. 93). Ello 
marca una diferencia "ontológica" infranqueable: el "ser", del cual parte la filosofía, así como el "ser" mismo del derecho, son, en una y otra vertiente iusfilosóficas, distintos, muy distintos. ¿Cómo conciliarlos entonces?

No obstante esa dificultad, podríamos decir en primer lugar que dado que el iuspositivismo ha cultivado el derecho positivo mucho más que el derecho natural, aquél puede "aportar" elementos importantes a éste ya que la escuela del derecho natural no desdeña al derecho positivo, y obviamente siempre y cuando no entre en contradicción con el derecho natural que le sirve de punto validante; los aportes del iuspositivismo a una tercera vía conciliadora podrían ser sintéticamente los siguientes: la importancia de la elaboración formal de la ley, el estudio de la norma positiva en sus componentes, el lenguaje jurídico, la sujeción del Estado al derecho positivo, la importancia de la sociedad como factor para el nacimiento del derecho, la capitalidad de la cultura humana, el derecho procesal, y la teoría del derecho.

Dados esos aportes, ¿no pueden éstos ser aceptados por una tercera vía integradora? Desde luego que sí, según la tercera vía iusfilosófica.

¿Y qué decir de si hay apertura del iuspositivismo al derecho natural? También, en lo concerniente a la justicia, legado inveterado del iusnaturalismo clásico.

Pues bien, en medio de la inicial batalla entre el iusnaturalismo y el iuspositivismo, hace ya más o menos un siglo se abrió paso, precisamente, la tercera vía iusfilosófica, que sumó aportes de una y otra posturas iusfilosóficas, e incluso voló más lejos que ellas dos.

La tercera vía iusfilosófica, aceptó del iusnaturalismo, como se acaba de decir, el viejo y tradicional concepto de justicia, descartado del derecho positivo definitivamente por Kelsen cuando sostuvo en su Teoría pura del derecho lo siguiente:

"Para que el orden moral sea distinto del orden jurídico es preciso que el contenido de las normas morales no se confunda con el de las normas jurídicas, y que no haya, por consiguiente relación de delegación del derecho a la moral o de la moral al derecho. Gracias a esta condición resulta posible pronunciar un juicio moral sobre un orden jurídico considerado en su conjunto o sobre cualquiera de las normas que lo constituyen. Mediante este juicio puede comprobarse la conformidad u oposición entre tal norma moral y tal norma jurídica, es decir que desde el punto de vista de la moral la norma jurídica es buena o mala, justa o injusta.

Hay aquí un juicio de valor emitido sobre la base de una norma moral y, por consiguiente, extraño a la ciencia del derecho, puesto que no es pronunciado sobre la base de una norma jurídica. 
Los únicos juicios de valor que la ciencia del derecho podría pronunciar teóricamente son aquellos que comprueban la conformidad u oposición entre un hecho y una norma jurídica. El hecho sería entonces declarado lícito o ilícito, legal o ilegal, constitucional o anticonstitucional” (Kelsen, 2001, pp. 43-44).

La apertura a la "justicia" iusnaturalista -negada por Kelsen-, la vemos en autores de la tercera vía iusfilosófica como Gustav Radbruch, en su teoría jurídico-valorativa; Dworkin, en su teoría de los principios generales del derecho (entre los cuales sobresale el de justicia); Rawls, en su Teoría de la justicia; Habermas, en su teoría de las reglas de la comunicación (que, aunque no mencionan directamente a la justicia, son realmente reglas de justicia, tales como la libertad de expresión, la veracidad, ningún privilegio, ausencia de coacción); Kaufamnn, en su definición de la filosofía del derecho como una doctrina de la justicia; Amartya Sen, con su "Idea de la justicia", etc.

Pero también existe una apertura de la tercera vía iusfilosófica al concepto de "equidad", heredado igualmente del iusnaturalismo: Aristóteles, Tomás de Aquino, etc.; ello lo apreciamos en especial en la denominada "escuela hermenéutica” de la tercera vía iusfilosófica (Kaufmann, Beuchot...).

Así las cosas, esto es, el reconocimiento de ciertas categorías del derecho natural (¿podríamos decir de segundo nivel?), así como de aportes del iuspositivismo (¿también de segundo nivel?), se ha ido desarrollando y tomando cuerpo la tercera vía iusfilosófica.

¿Cómo dar una "noción” de la tercera vía iusfilosófica con los elementos ya mencionados? Acudamos una vez más a Arthur Kaufmann quien nos da algunas claves para entenderla:

a. La T.V.I acepta que entre iusnaturalismo y iuspositivismo no hay una relación "excluyente" sino "complementaria" (Kaufmann, 2002a, p. 93), así sea en aspectos tales como los conceptos de justicia, equidad, ley positiva, etc. No hay identidad en el punto del ser del derecho, que sabemos es radicalmente distinto, pero sí en otros aspectos.

b. La T.V.I, no mira a los absolutos de la naturaleza humana (escuela del derecho natural), ni de la ley positiva (iuspositivismo), como fuentes primeras del derecho, pero sí mira a lo que es "evidentemente injusto"; es una mirada, pues, no positiva o afirmativa sino negativa de la justicia: lo evidentemente injusto no es derecho (p. 93). En efecto, si se observa la historia del concepto de justicia en el derecho natural clásico vemos allí que las construcciones de justicia son todas positivas: la justicia es tal o cual cosa (por ejemplo: justicia es dar a cada 
quien lo suyo); la T.V.I., al contrario, mira lo "evidentemente injusto", no lo "evidentemente justo".

c. La T.V.I. ve muchas posibles "variaciones" en las "soluciones judiciales"; no hay una única posible solución (p. 93). Esta característica de la T.V.I., en honor a la verdad, la encontramos ya en la escuela del derecho natural en sus tradicionales conceptos de equidad (Aristóteles) y equivalencia (Tomás de Aquino).

d. Añadiendo a Kaufmann algo más, de nuestra parte podemos decir que la T.V.I. es "existencialista", es decir, se centra a la actividad judicial, y no tanto en las teorías acerca de las fuentes del derecho (claro está que ubicados en este punto, podría preguntarse si el existencialismo es verdadera filosofía ya que supuestamente el existencialismo no mira al "ser" -tradicional concepto de la filosofía- sino al "existir"; pues bien, puede decirse que el existencialismo -al menos el existencialismo original de Kierkegaard- no desconoce del todo el ser sino que lo mira al mismo tiempo junto con la existencia; en términos de derecho ese ser y ese existir son el hombre y la norma, conjuntamente mirados y valorados).

Dicho lo anterior pasemos a ver algunas de las principales escuelas de la tercera vía iusfilosófica:

1.- Gustav Radbruch. Es el iniciador de esta postura iusfilosófica en los primeros años del siglo XX.

Trata de ir más allá del "formalismo" racionalista del derecho, heredado de Kant y de Hegel, y mira al contenido del mismo, compuesto de "valores" que forman la justicia pero en el sentido de señalar que no es derecho lo notoriamente injusto (se adscribe así, en parte, al iusnaturalismo); ahora bien, destaca del iuspositivismo la "seguridad jurídica" que proporciona la ley positiva: el derecho sin seguridad, dice Radbruch, no es derecho (se adscribe así, en parte al iuspositivismo).

De esta manera Radbruch aúna las viejas escuelas del iusnaturalismo y del iuspositivismo en los aspectos anotados: justicia con valores y seguridad positivista de la norma. Para Radbruch las normas son verdaderamente en derecho si se remiten a la justicia, que es fin del derecho, justicia nutridas de valores, sin escala jerárquica prefijada (relativismo); pero a su vez, en aras de la seguridad jurídica (iuspositivismo), habrá que fijar en cada caso en la sentencia del juez el imperativo exterior de las normas. De esta manera, las normas positivas miran a la justicia valorativa como su referente, pero la 
justicia valorativa mira también a las normas positivas para dar seguridad. Se hace así una simbiosis de ambos polos.

\section{2.- La hermenéutica jurídica.}

La interpretación del derecho ha tenido una historia muy interesante y valiosa. Veámosla brevemente:

Ella empezó por el "rigor exegético" de la norma y así se duró por mucho tiempo; separarse de la textualidad legal era sinónimo de peligrosidad para el derecho; interpretar debía ser una labor excepcional o exigua (Beuchot, 2006, p. 145).

Se sostenían en aquella época como dogmas que "dura lex sed lex", y que "in claris non fit interpretatio"; eran los criterios interpretativos del derecho de ese entonces.

Savigny, célebre jurista cultor del derecho romano, sostuvo, en el siglo XIX y más allá de esos dogmas textualistas, que criterios interpretativos del derecho eran: desde luego el ineludible apego a la ley (exégesis), criterio absolutamente relacionado con el arreglo a la gramática, pero, además, acudir a la historia, a la época, en la que se dictó la norma, y a la sistematicidad o relación de las normas jurídicas.

Esa fue la manera de interpretar que se mantuvo hasta la llegada de la hermenéutica jurídica; pero puede decirse que Savigny, en buena medida, propició este cambio de mentalidad "abierta" - no restrictiva- de interpretación del derecho.

La llamada conciencia hermenéutica propia de la tercera vía iusfilosófica busca un punto medio en la interpretación del derecho. El derecho natural clásico partía del siguiente postulado: "veritas est adaequatio intellectus et rei", la verdad es la adecuación del intelecto a la cosa; la cosa exterior es pues el objeto a aprehender por el intelecto; el intelecto es pasivo al objeto; el intelecto es un fotógrafo de la realidad, receptor suyo; el objeto exterior domina al intelecto humano: es el "objetivismo" puro tanto en la filosofía en general como en el derecho en particular.

Pues bien, la escuela hermenéutica sostiene que esa pureza objetiva no se puede desligar de las condiciones del sujeto: personales, históricas, circunstanciales; el sujeto pensante cuenta a la hora de apresar el objeto de conocimiento; el objeto no puede ser puro y absoluto sino que cuentan las condiciones del sujeto que conoce, aunque tratando de evitar el "subjetivismo", que atomizaría socialmente. Se trata entonces de lograr un 
punto medio en el conocimiento; sujeto y objeto cuentan, cada uno, con un $50 \%$, por decirlo de alguna forma. Tarea difícil pero posible y humanizadora.

Es lo que dijo Ortega y Gasset pero que lo podemos repetir ahora quizá con nueva fuerza: "Para nosotros la vieja discordia está resuelta desde luego; no entendemos cómo puede hablarse de una vida humana a quien se ha amputado el órgano de la verdad, ni de una verdad que para existir necesita previamente desalojar la fluencia vital" (El tema de nuestro tiempo, p. 90).

La hermenéutica jurídica, siguiendo a otros autores en su lenguaje propio, no pretende ser ni univocista ni equivocista, no pretende tener una verdad objetiva "absoluta", ni caer en el subjetivismo "absoluto"; se trata de un equilibrio, de una armonía entre lo unívoco y lo equívoco, entre lo objetivo y lo subjetivo; leamos unas palabras a este respecto de Mauricio Beuchot: "Pero también me he esforzado por señalar los peligros de las hermenéuticas univocistas y las hermenéuticas equivocistas, sobre todo de estas últimas, que inundan el mapa de las hermenéuticas actuales. Por eso, he hecho un llamado a una hermenéutica analógica, que usa la analogía, la cual se ubica en medio de la univocidad (que casi siempre resulta inalcanzable) y la equivocidad (que lleva a la disolución)" (2006, p. 139). Como se puede observar, en este autor la anterior proporción de 50 y 50 entre lo objetivo y lo subjetivo, que señalamos atrás, ya no aparece tan clara, pues se ve una relativa superioridad de lo objetivo frente a lo subjetivo; creemos en las ventajas de una "cierta prevalencia" de lo objetivo sobre lo subjetivo en la vida social, política y jurídica, pues si prevaleciera lo subjetivo sobre lo objetivo se corre el riesgo de caer en la disolución de la vida sociopolítica; es una traducción del viejo principio de que el bien general debe primar sobre el bien particular, tan necesario para vida en la polis.

3.- Teoría de la argumentación jurídica. Busca la suma de argumentos en el debate judicial, no el reduccionismo a la naturaleza humana ni a la ley positiva, y, por tanto, de cara a una mejor sentencia del juez, predica que los argumentos son "múltiples", no hay en la mayoría de los casos judiciales, un solo argumento sino varios que conducen a alcanzar la justicia judicial más plenamente: la seguridad jurídica, la justicia, la valoración de las consecuencias, el sentimiento jurídico, la practicabilidad del fallo, etc. (Kaufmann, 2002a, pp. 101 y ss.).

4.- Teoría de los principios generales del derecho. Predica que existe la necesidad de sujetarse a la ley positiva, o a la regla jurídica (hasta ahí positivismo jurídico), pero que, en los "casos difíciles" (hard cases) -que 
son la mayoría de las veces en el mundo jurídico y judicial-, si la ley o la regla no proporcionan claridad para decidir el caso, debe acudirse a los principios generales del derecho, que para Ronald Dworkin son tres: la justicia, la imparcialidad (iusnaturalismo), y el arreglo al Estado de derecho (iuspositivismo) (Kaufmann, 2002b, pp. 105 y ss.).

5.- Dijimos atrás que dentro de la T. V.I. podemos incluir las actuales teorías del contrato social. Aquí me referiré a tres autores:

a. John Rawls, neocontractualista, basado en la idea de justicia (concepto del derecho natural), dice que ésta se consigue con base en las instituciones formales heredadas del contrato social liberal (iuspositivista). Aquí se ve la amalgama de las dos concepciones iusfilosóficas.

b. Jürgen Habermas, basado en el contrato social de Rawls, pretende introducir "nutrientes" para el diálogo contractual social por la justicia; dice a este respecto Arthur Kaufmann: "Estas cualidades formales del discurso las ve Habermas en las condiciones de una situación dialogante ideal: igualdad de posibilidades (chances) para todos los participantes en el discurso, libertad de expresión, ningún privilegio, veracidad, ausencia de coacción" (Kaufmann, 1998 p. 50).

Pero, como se puede deducir, tales nutrientes, no son más que “derechos naturales" de la persona humana (herencia del derecho natural de la Modernidad) para el contrato social (herencia del iuspositivismo naciente de los primeros tiempos).

c. Arthur Kaufmann, crítico del excesivo formalismo de Rawls y Habermas, se centra en la persona humana relacional; acepta algo del contrato social liberal positivista, pero lo "supera" mediante el recurso a la persona humana iusnaturalista (con carácter relacional, experiencial, empírico e histórico); leámoslo directamente:

"Nuestras meditaciones se han aguzado para la pregunta decisiva: ¿Cuál es en adelante el objeto, el tema, del discurso de la justicia? Conforme a todo lo dicho hasta aquí, este objeto (en ningún caso entendiéndolo sustancial) no puede encontrarse ni completamente fuera del proceso de creación jurídica ni enteramente en él, pues de otra manera habríamos caído otra vez en la ontología sustancial o en el funcionalismo. Necesitamos un fenómeno que es al mismo tiempo ontológico y procesal. Lo que se busca sólo puede ser el hombre, pero no el hombre puramente empírico, ni tampoco el hombre meramente como noumeno, sino el hombre como persona, es decir, como 
el conjunto de las relaciones en que se encuentra el hombre con los otros hombres o con las cosas" (Kaufmann, A. La filosofía del derecho en la posmodernidad, 1998, p. 67).

6.- Más recientemente encontramos otras teorías que podemos incluir dentro de la T.V.I., tales como las de Amartya Sen, y Robert Alexi.

a. Amartya Sen, se centra en primer lugar en el valor de la justicia, valor proveniente, como ya hemos dicho, del derecho natural clásico, pero no en el sentido positivo sino en el de lograr reducir o eliminar la injustica evidente.

Dice Sen a este respecto: "La identificación de la injustica reparable no sólo nos mueve a pensar en la justicia y la injusticia; también resulta central... para la teoría de la justicia" (Amartya, 2010a, p. 11); y, siguiendo la característica de la T.V.I. de "sumar" a los tradicionales contrincantes del iusnaturalismo y del iuspositivismo -aunque superándolos-, aúna para la consecución de la justicia a las "instituciones formales" típicas del liberalismo de Locke y otros, con los "comportamientos reales de las personas".

\section{Leamos nuevamente a Sen:}

"En contraste, muchas de las principales teorías de la justicia se concentran de manera abrumadora en cómo establecer 'instituciones justas', y conceden una función subsidiaria y dependiente a las cuestiones relacionadas con el comportamiento... El énfasis en las vidas reales para la evaluación de la justicia tiene muchas implicaciones de largo alcance para la naturaleza y el alcance de La idea de la justicia" (2010b, p. 15).

b. Robert Alexi, separándose del rasgo iuspositivista de separar moral y derecho, por el contrario predica que la ley incluye el concepto de pretensión de corrección.

Leamos a Bulygin hablando de Alexi:

"Los partidarios de la teoría del derecho natural sostienen la tesis de que entre derecho y moral existe una conexión necesaria, esto es, conceptual..., mientras que los filósofos del derecho más orientados hacia el positivismo sostienen la llamada tesis de la separación, de acuerdo con la cual el derecho es conceptualmente independiente de la moral, existiendo entre estos dos fenómenos sociales, sólo relaciones empíricas, es decir, contingentes.

En una serie de publicaciones, Robert Alexi, adujo diferentes argumentos en defensa de la tesis de la vinculación. Entre estos argumentos, el así 
llamado argumento de la corrección desempeña un papel central..." (Alexi \& Bulygin, 2001, pp. 41-42).

Y el mismo Alexi, en una visita a Bogotá, dijo expresamente en una entrevista a la publicación Ámbito Jurídico de 17 a 30 de octubre de 2011 lo siguiente:

"En filosofía del derecho, mi gran opositor es Joseph Raz..., el más radical de los positivistas exclusivos. Nuestro principal enfrentamiento es por el concepto de ley, ya que él excluye las razones morales del discurso jurídico, a diferencia de mi teoría de la pretensión de corrección que debe tener el derecho".

7.- Critical legal studies.

Arthur Kaufmann (2002) incluye a esta escuela dentro de las de tercera vía iusfilosófica.

Razón para incluirla sería, ya a nuestro parecer, la de ser una escuela eminentemente sociologista, $y$, por lo tanto, iuspositivista (no olvidemos que ya atrás dijimos que el iuspositivismo, entre sus escuelas, cuenta con la escuela sociológica según la cual el origen del derecho se encuentra en la sociedad); también sería razón para incluirla a nuestro juicio en la tercera vía iusfilosófica el que la Critical admite valores perennes del derecho tradicional tales como la igualdad, en concreto para con los desfavorecidos de la sociedad (Gargarella).

En efecto, en Gargarella se mencionan varios desventajados a los que el derecho tradicional no llega: niños, inmigrantes, aborígenes, mujeres, para lo cual deberían haber "reformas" institucionales, haciendo que los derechos humanos sean "de veras" universales (debiendo haber, por ejemplo, reparación de las víctimas), propiciando un "derecho alternativo", nacido de la entraña de los pobres y marginados, que debe llevar a crear figuras jurídicojudiciales más allá del Estado: jueces de paz, mecanismos de conciliación, etc. (cosa que nos parece plausible, si se tiene en cuenta nuestra postura de una "filosofía del derecho social", que más adelante expondremos).

Otra razón para incluirla en la tercera vía iusfilosófica sería la de que la Critical admite la "opacidad del derecho" (Cárcova), rasgo que también caracteriza a la tercera vía tal como quedó expuesto al decir que ella "es un sistema abierto que admite variaciones y no verdades absolutas" en todos los casos.

También sería razón para incluir la Critical dentro de la tercera vía iusfilosófica el que se trata de una postura que consideramos "existencialista" 
más que ontologista: no se trata tanto de "declaraciones" positivistas de derechos, o de hablar del "origen" del derecho -temas que no se mencionan en estos autores-, cuanto de "dar" los derechos que tienen los desfavorecidos de la sociedad.

Sin embargo, hay quienes dicen que esta escuela no admite ser clasificada en ninguna parte - por lo cual no deberíamos incluirla en la T.V.I.- pues no es amiga de las "clasificaciones", y en tal sentido tendríamos que tratarla como escuela "aparte" de la tercera vía iusfilosófica.

¿Por qué se dice que no sería parte de la tercera vía?; respuesta: por no "sumar"-como hacen las anteriores posturas atrás vistas-aspectos "positivos" tanto del derecho natural (vgr. la justicia) como del iuspositivismo (vgr. los aportes sobre la norma positiva); al contrario, la Critical, en su versión argentina concretamente (vgr. "la teoría crítica del derecho", de Cárcova), lo que hace es hacer una crítica sin compasión a todos los sistemas anteriores (iusnaturalismo y iuspositivismo), así como a todo aquello que se considere "hegemónico" dentro del derecho: al derecho natural lo desconoce al parecer del todo, y a KelSen, por ejemplo, también lo critica con ferocidad: en tal sentido llega a hablar de "teorías postpositivistas del derecho" (Cárcova); en consecuencia, esta escuela "resta", quita, elimina lo anterior existente de la filosofía del derecho, en buena parte por considerarlo hegemónico, y propugna por ir más allá del pasado iusfilosófico por considerarlo ineficaz, que no ha servido.

El método por antonomasia de la Critical es la oposición, la dialéctica, la crítica; a este método, creemos de nuestra parte, que la Critical lo ensalza, y ello es correcto desde luego si tenemos en cuenta que la filosofía en general y la iusfilosofía en particular utiliza este método básico, que, sin duda reporta grandes avances en el conocimiento.

Sin embargo, no compartimos la extrapolación de este método como si fuese el único; consideramos, siguiendo el postulado del punto medio, que en los métodos debe haber, en su conjunto, también un "punto medio"; no se trata de ensalzar unívocamente un solo método; la historia ya ha aportado varios y eso es sabiduría acumulada que debe valorarse, lo cual no debe significar tampoco posiciones acríticas, creemos que un cierto grado de de-construcción es benéfico para el filósofo y para el iusfilósofo, pero no se puede prescindir alegremente de la sabiduría alcanzada a lo largo de los siglos por la racionalidad y las convicciones humanas; es tarea del hombre hacer continuos discernimientos, pero también, como parte del discernir, admitir los muchos logros adquiridos por la humanidad. 
Por otra parte se debe decir que si por hacer dialéctica se llega a una inestabilidad continua, ello conduciría de paso a una inestabilidad del derecho; el derecho es así, es parte de su naturaleza, esto es, que el derecho necesita de un algo de seguridad; no se olvide que aun la postura de Descartes, la de la duda, no era para quedarse perpetuamente en ella sino para llegar a alguna verdad cierta, que, en su caso fue el cogito ergo sum; pero es que además el hombre no puede vivir en un continuo "no estar", inseguro, el hombre, y el derecho también, necesitan un algo de seguridad, de estabilidad, de certeza.

Desde luego el derecho en su referente social es cambiante, histórico, e incluso la actividad judicial es también dinámica, pero a algún punto de llegada debe irse tanto en la ley como en el fallo judicial. Ya Rousseau decía que para el bien del derecho y de la sociedad -y eso no sólo lo dijo Rousseau sino también muchos pensadores como Tomás Moro, en Utopía- era menester que la ley fuera estable, duradera.

Contra lo anterior podría objetarse que la sociedad de hoy es mucho más veloz que en otras épocas; pues bien, precisamente por ello quizá, debería admitirse una esfera de valores más o menos permanentes so pena de evaporarse en la nada; el hombre es naturaleza y es historia; en ello debe bregarse por conseguir un punto medio equilibrado. 


\title{
III. REFERENTES MATERIALES DEL DERECHO DEDUCIDOS DE LA ANTERIOR HISTORIA. VENTANAS DEL DERECHO
}

\begin{abstract}
"El interrogarse sobre el por qué de las cosas es inherente a su razón (del hombre), aunque las respuestas que se han ido dando se enmarcan en un horizonte que pone en evidencia la complementariedad de las diferentes culturas en las que vive el hombre"

(Juan Pablo II).
\end{abstract}

Tratar el tema de los referentes del derecho -el por qué de las cosas, esto es, el origen de éstas-, es una de las tareas más tradicionales y perennes de la iusfilosofía.

La filosofía general ha tenido como uno de sus tesoros constitutivos el de ir a lo primero (también se habla de "lo último", pero es preferible hablar de lo primero pues la expresión lo último es demasiado equívoca), ir al ser, a lo que da consistencia al mundo, a toda la realidad que circundante.

Las ciencias particulares se detienen en el estudio de lo inmediato: la materia, la psiquis, la salud, la aplicación de la justicia entre las partes, la composición química, los astros, el número..., pero la filosofía desde su nacimiento se preocupó por lo que está más allá de lo que se ve, se ocupó no por lo inmediato sino por un algo (debe reconocerse que el lenguaje mismo es pobre para detectar el ser), que, se considera es el sostén de todo el mundo visible e invisible; la filosofía se pregunta por las cosas más esenciales, rotundas y contundentes que pueden interrogar al espíritu humano: es lo que se ha denominado también metafísica, es decir, aquello que es universal, lo más general y totalizante, el ser, a través de nombres que tratan de expresarlo ya que el ser es infinito y, dada la limitación de la mente humana, sólo se van descubriendo aspectos de él, facetas de esa especie de gran diamante que es el ser, tales como el agua, el fuego, el aire, la tierra, el número, la vida...

En línea con lo anterior, la iusfilosofía también ha tratado de buscar el origen, la fuente, el productor general, el ser, del derecho: ¿qué hay detrás de todo el derecho que vemos en primera instancia? ¿Por qué existe el 
derecho? ¿Por qué nació el derecho? ¿Para qué existe el derecho? ¿Cómo existe el derecho?

Sabemos que las distintas áreas del derecho se detienen en aspectos puntuales e inmediatos del mismo: el derecho laboral (el mundo del trabajo), el derecho comercial (el mundo de los intercambios de bienes), etc., pero la iusfilosofía busca ir más al fondo de esos distintos tipos de derecho, trata de ir derecho en sí mismo, y no en sus aspectos parciales y fragmentarios.

Precisamente por esas preguntas es por lo que la iusfilosofía trata de ir a las fuentes del derecho, a su nacimiento primero, a sus raíces más profundas; aquí se denominarán referentes materiales del derecho; de ello trataremos a continuación. No veremos las llamadas "fuentes formales" que sólo se fijan en la expresión exterior del derecho y que pertenecen a otra área del conocimiento jurídico: la teoría jurídica.

Después de haber visto la síntesis histórica de la iusfilosofía resulta más o menos fácil deducir las principales fuentes materiales, o referentes materiales, de aquélla. Veamos:

A. LA PERSONA HUMANA

"Ordo non est substantia, sed relatio" = el derecho no es sólo sustancia (tal vez individuo aislado, podriamos traducirlo), es ante todo relación

(Tomás DE AQuino).

La persona humana es la fuente por excelencia del derecho según la escuela del derecho natural.

A la persona se le puede entender al menos desde tres puntos de vista: a) como "persona divina"; en la Teología Católica Dios es uno y trinitario, esto es, está compuesta por tres personas divinas; la aplicación del concepto de persona a Dios dentro de la Teología Católica, tuvo su fuente en la filosofía griega (Mounier, 2001, p. 28); b) como "persona humana", esto es, animal racional, al menos si nos atenemos a una definición si quiera, la de Aristóteles; la persona humana es tratada tanto por la filosofía antropológica (aunque la antropología habla más propiamente de "hombre", de humus, tierra, con raíces en el Génesis de la Biblia, como también es tratada por el derecho; c) y como "persona jurídica", concepto ficción que significa que los grupos jurídicos constituidos por la voluntad humana son sujetos de derechos y obligaciones; es tratada de manera especial por la Teoría del derecho. 
En filosofía del derecho sólo corresponde tratar el segundo punto de vista: la persona humana. Uno de los grandes temas de la filosofía, y también de la filosofía del derecho, es el de la persona humana (desde luego, en el derecho no basta el concepto de persona humana como sujeto, objeto y fuente de derechos y obligaciones; también es capital, por decirlo así, en el otro extremo, el de "Estado" como fuente, sujeto y objeto de derechos y obligaciones; ahora bien, el Estado existe para la persona y no al revés, a no ser que se acepte el totalitarismo de Estado donde la persona se diluye en él: es clásica la fórmula del totalitarismo de Estado fascista: todo dentro del Estado, nada fuera del Estado, nada en contra del Estado, por lo cual es fácil colegir que la persona humana se evapora en el Estado; y, si se trata del totalitarismo de Estado comunista, también es fácil deducir que la persona se esfuma en aras de lo común=comunista); (y no sólo el Estado es fuente, sujeto y objeto de derechos y obligaciones, también lo es la familia, la sociedad, la naturaleza, como instancias intermedias entre persona y Estado, que son igualmente sujetos, objetos y fuentes de derechos y obligaciones).

Es entendible que por encima de la naturaleza física, de los animales, de las plantas y de los minerales, el ser humano tiene el lugar privilegiado entre las cosas que se ven, se intuyen o se piensan. A este respecto podemos traer a colación las siguientes palabras: "No se equivoca el hombre al afirmar su superioridad sobre el universo material y al considerarlo no ya como partícula de la naturaleza o como elemento anónimo de la ciudad humana. Por su interioridad es, en efecto, superior al universo entero" (Concilio Vaticano II).

Pero, ¿qué es, la persona humana, y qué papel tiene frente al derecho?

La palabra persona nace en Grecia con el significado de máscara; quizá una primera aproximación a máscara es que la persona humana en esa cultura estaba como oculta en su verdadera dimensión, aún no se había descubierto a cabalidad qué era la persona humana.

De hecho en Grecia, la polis, esto es, la ciudad, ocupó probablemente un puesto más importante; la pena más vergonzosa que se podía imponer era el destierro de la polis, el llamado ostracismo, significando que salir de la polis era morir en vida (aún hoy, la extradición de una persona sigue siendo una pena considerable); la polis dominaba a la persona; además, se cuenta que ARISTÓTELES sólo justificaba el aborto cuando en la ciudad había exceso de habitantes: ello porque el número de habitantes de la polis era algo esencial y no podía exceder de un cierto número de habitantes bajo riesgo de que la ciudad se degenerara. 
Sin embargo, la persona empieza a aparecer en alguna medida en el pensamiento griego: un presocrático como Protágoras ya dice que "el hombre es la medida de todas las cosas"; más adelante, Sócrates empieza una batalla por la dignificación de la persona a través de su predicación de la virtud: la virtud dignifica a la persona; y por esa prédica entrega su vida a la pena de la cicuta; y el "conócete a ti mismo" del mismo Sócrates también indica que la persona vale ante todo por su capacidad de introversión, de reflexión, de interioridad, tarea que se imponía precisamente como premisa para entrar al templo de los dioses, al oráculo donde ellos hablaban (ahí se observa, por cierto, un vínculo estrecho entre hombre y Dios).

Una segunda aproximación a la palabra persona humana como máscara es la de que ésta es misterio, esto es, que por más que sepamos cosas de la persona, sigue siendo un enigma; y esa consideración es para respetar profundamente; eso es precisamente filosofía; ¿quisieron decir eso los griegos? ¿No trata Aristóteles la filosofía -racional por naturaleza- como cercana a la mitología, a lo sacro, a lo misterioso? Pues sí, en Aristóteles se observa un respeto profundo por el mito. ¿Y no habla el mismo Aristóteles de que la justicia más humana no es la aritmética sino la proporcional, dando a entender con ello que el ser humano no es aprehensible del todo en estadísticas y números exactos, tal como la cultura de hoy lo quiere hacer ver?

El cristianismo, posterior a la cultura helénica, desveló mucho más la idea seminal hasta ahí existente de persona humana (de Protágoras, Sócrates, Aristóteles): ya no se trata de la persona masa, múltiple, diluida en la polis, sino del individuo concreto - aunque en vida de comunidad-, que es reflejo de la comunidad o Trinidad de Dios; el cristianismo valoró la comunitario griego pero desveló la individualidad del ser humano oculta en Grecia. Más allá de un destino ciego e impersonal, el cristianismo sostiene además que existe un destino hacia un Dios también personal; a lo anterior habría que sumar que dentro del cristianismo, a través de la libertad personal, el hombre puede experimentar una metamorfosis del "corazón", una conversión verdadera del mal a la vida de amor en Dios (Mounier, 2001, pp. 26-28).

La persona como máscara, oculta, misterio, según los griegos, es fácil pensar que la cultivó de manera especial el cristianismo al tratar a la persona como algo cercano a Dios -el hombre es imagen semejante a Dios, como dice Yavé en el Génesis-; por eso no debe sorprender que se hable de que la persona humana es "sagrada", sinónimo de misterio.

Hoy en día, sin embargo, la idea de persona como misterio está lejos de concebirse; la época actual es secular, se ocupa ante todo de la sociedad; 
se trata, trayendo a cuento el título de un libro de Ortega y Gasset, de una verdadera "rebelión de las masas"; y, precisamente por la de-sacralización o de-mascarización de la persona humana, es por lo que considero que es tan menospreciada hoy: torturas, secuestros... y una lista interminable de agresiones a la persona.

Pero... ¿todas las consideraciones anteriores sobre la persona humana qué tienen que ver con el derecho?

La persona humana no es sólo un mundo cerrado e impermeable; es in-dividuo, es decir, in diviso, no dividido, es soledad (no solitarismo individualista), y, al mismo tiempo, ser sociable, necesitado de los demás, con un lenguaje de comunicación hacia fuera y un mundo de manifestaciones más que lo hacen constitutiva y fundamentalmente social, relacional, comunicativo; Mounier, p. 50; enfatiza en esta socialidad del hombre; personalmente, creo mucho en el valor de la soledad también como constitutivo de la persona humana junto con la socialidad; creo que debe decirse esto hoy con especial fuerza cuando esa soledad ha sido tan despreciada y casi que anulada por la "cultura" del ruido exterior).

Pero concretándonos más precisamente a esa dimensión social de la persona humana, ella tiene que ver sobremanera con el derecho: ordo non est sustantia sed relatio, dice Tomás de Aquino; esa relatio siempre ha tenido que ver tradicionalmente de manera particular con el derecho: la persona es relacionalidad y el derecho también es relacionalidad; ahí se encuentran persona y derecho.

El derecho en cuanto relación tiene a su vez dos dimensiones: deberes, por una parte, y derechos, por otra. Por eso las Constituciones Políticas hablan hoy de derechos y de deberes conjuntamente; por ejemplo, en nuestra Constitución Política de 1991 se consagran los derechos en los aa. 11 a 94, y los deberes en el a. 95. Toda interpretación o hermenéutica jurídica debe, pues, hacerse bajo esta doble óptica: derechos y deberes a la vez, al mismo tiempo, para así conseguir un sano equilibrio jurídico, un punto medio; de lo contrario, si sólo se ve el derecho como derechos, se cae en el individualismo; y si sólo se ve el derecho como deberes, se terminan sacrificando los derechos personales.

Relacionado con lo anterior no sobra recordar que históricamente la humanidad fue primero comunitarista (en sentido muy general, no en el sentido más reciente que posee la palabra "comunitarista"), por lo que pensó ante todo en deberes: deberes para con la polis, deberes para con la naturaleza...; posteriormente, a partir del liberalismo individualista, se tornó en humanidad de derechos; hoy todavía asistimos a una época que pareciera 
centrarse sólo en los derechos, de manera individualista; no se habla en la misma proporción de deberes como sí de derechos. ¿No es hora de lograr el equilibrio entre ambos polos?

\section{A.1. UNA POSICIÓN IUSFILOSÓFICA ACTUAL -QUE VA CONTRA CORRIENTE Y POR ESO ES IUSFILOSÓFICA-, Y DE PETICIÓN DE MORALIDAD EN EL DEBATE PÚBLICO -NO DE MORALISMO-.}

"Nuestras leyes son, por definición, una codificación de la moral, buena parte de la cual se fundamenta en la tradición judeocristiana"

(Charlie Crist).

En filosofía jurídica es más o menos general-desde luego hay excepcionesencontrar en sus textos teorías, cuestiones muy generales, y pocas veces se debaten o se toman posiciones concretas frente a problemas reales; a nuestro juicio, dichas teorías deben aterrizar en los casos "sangrantes" de la vida real.

Hemos hablado hasta aquí algo sobre la persona humana; ¿y qué es lo que hay dentro del vientre materno fruto de la unión de un espermatozoide y de un óvulo humanos? ¿Y qué es un hombre en estado vegetativo o en coma?

a. Puede que, en el primer caso, esto es, un feto, llámese pre-embrión, embrión, etc.-, no sea tenido en cuenta por la terminología jurídica como "persona humana", tal como ocurre por ejemplo en el Código Civil Colombiano, art. 92, y también en la sentencia sobre despenalización del aborto en Colombia en ciertos casos, del año 2006.

En el primer caso (Cons. Colombia, art 92), la persona humana es sólo aquélla que se ha separado del cordón umbilical una vez ha nacido el feto; pero... ¿puede negarse que sea un "ser humano" lo que existe antes de nacer? ¿No sostiene la filosofía más básica que el efecto sigue a la causa? Puede ser que no haya persona humana en su totalidad, con un cerebro desarrollado, pero hay allí un algo humano en desarrollo; por ello mismo... ¿no amerita una protección jurídica, tal como también lo establece el art. 92 mencionado?

Para abordar este espinoso, antiguo y disociador tema, parece luminoso -y hasta podría decir valiente frente a un tratamiento generalizado que esquiva el problema- el modo en que Michael Sandel se basa para tratar la cuestión del aborto; en síntesis muy apretada, el planteamiento de Sandel es el siguiente: 
Frente al aborto existen dos posturas:

a) La que dice que el aborto debe ser tratado como una expresión de la autonomía o libertad del individuo, posición típica de la llamada "razón pública liberal", que exalta la libertad individual a cimas ilimitadas, y donde el Estado debe ser neutral a doctrinas morales y religiosas.

b) La postura que dice que detrás del aborto se contiene un valor concreto y superior como es la vida humana, tan esencial para todo tipo de sociedad, y por ende para el Estado, sin la cual la sociedad y el Estado se disolverían.

Se objeta a la primera postura -la de la razón pública liberal-, que la libertad exaltada puede dar lugar a todo tipo de cosas: tal vida sí vale, tal no vale; el matrimonio puede ser cualquier tipo de unión, etc.; además se objeta que se debe desequilibrar la balanza a favor del valor individual y social de la vida humana, por encima del valor de una libertad sin límites, valor éste de la libertad que es grande, claro, pero que podría llevar a desordenar y desintegrar a la sociedad y al Estado si se la tiene como un absoluto, pues cada uno iría a lo suyo, atomizando a la sociedad (Sandel, 2011, pp. 277 y ss.).

¿En realidad de verdad, ello es así, es decir, que la vida humana prima sobre la libertad?

No es tan claro en la facticidad, pues es sabido que existen legislaciones y jurisprudencias libertarias; en países como Colombia, por sentencia del año 2006, el aborto despenalizado está restringido a ciertos y determinados casos, con lo cual el libertarismo colombiano sería uno que podría llamarse limitado. Ahora bien, en Colombia -y parece que en general en las legislaciones del mundo-, la corriente es ir tras del aborto totalmente libre; es más, en Colombia ya, por sentencia del Consejo de Estado del año 2013, en contravía de la sentencia sobre el aborto de la Corte Constitucional mencionada del año 2006 que despenalizó el aborto para ciertos casos, se autorizó el misoprostol o píldora del día después, con lo cual quedó abierto el aborto prácticamente en todos los casos, y, de esa manera, Colombia entró en la onda del libertarismo total en materia de aborto, que exalta la libertad y autonomía individual más que el valor de la vida humana.

Ami juicio, este tipo de legislaciones o jurisprudencias libertarias totales -e incluso parciales-deberían introducir una especie de "cláusula de evaluación periódica" - por parte de una entidad gubernamental preferiblemente aunque no exclusivamente-, para mirar los resultados en su aplicación; nos parece 
conveniente una cláusula tal para leyes o sentencias de gran impacto social (como el aborto, la eutanasia, el consumo mínimo de drogas, el matrimonio de homosexuales, la adopción de niños por homosexuales, etc.) para corregir excesos, problemas o defectos que acarrean esas sentencias. Sería algo aproximado a lo que Karl Popper llama la "falsación", esto es, que si una tesis determinada falla en un caso concreto, tal tesis es falsa, quien dice expresamente a este respecto que "sería ampliamente posible la falsación de enunciados y contradecir teorías [en nuestro caso leyes y/o jurisprudencias], cuando encallen ante los hechos (Kaufmann, 1998, pp. 56 - 57).

b) En el segundo caso, cuando un hombre se halla en estado de coma profundo, irreversible, ¿es persona? ¿Es un ser humano? ¿No habría que pensar en lo que esa persona, estando consciente, desearía para sí al llegar a un estado crítico tal? ¿Y quién puede entender lo que esa persona desearía conscientemente? ¿No son acaso sus familiares más cercanos y su médico personal, de acuerdo al "espíritu" que esa persona en estado de coma a lo largo de su vida ha manifestado ser?

No sobra traer a colación para terminar, los "presupuestos históricos" (más concretamente en Estados Unidos) que Michael Sandel recuerda para exponer su punto de vista arriba resumido:

Sandel dice que en los debates sobre aborto, eutanasia, utilización de células madre embrionarias, matrimonio de homosexuales, etc., han existido dos posiciones políticas:

1.- La que dice que la moral y lo religioso deben "excluirse" del debate político dada la presencia del pluralismo y de la no posible unidad de conclusiones (posición proveniente de John F. Kennedy en los años 60s y después retomada en los años 70s, del siglo XX, por John Rawls), razones por las cuales se impone la "neutralidad" del Estado frente a la moral y la religión, y donde la verdad última es lo que diga el Tribunal Supremo, posición a la cual se adscriben sobre todo los llamados "progresistas".

De mi parte puedo decir que el argumento de que el pluralismo impediría tratar cuestiones morales y religiosas en la vida pública me parece indeseable, pues si lo invertimos, es decir, si no hubiera pluralismo y no hubiese sino una postura moral o religiosa, sería, ahí sí, algo peligroso: no habría sino imposición de esa postura, no habría sino teocracias, la disensión sería aplastada.

Y el argumento de que las posiciones morales y religiosas no posibilitan el consenso, no solamente me parece algo indeseable sino mentiroso, pues en 
la vida puramente política tampoco existen consensos siempre; lo lógico en cualquier materia, trátese de materia moral, religiosa, jurídica, económica, política..., es que haya varias posturas muchas de ellas disímiles, sin que siempre se logren consensos, por lo que hay que recurrir al criterio de la mayoría y de la objeción de conciencia, con tolerancia.

2.- Y la postura que dice que los "laicistas" se equivocan, pues personalidades célebres e influyentes en la historia de Norteamérica como Abraham Lincoln o Martin Luther King, siempre expresaron sus posturas morales y religiosas en la vida pública, siendo en realidad de verdad la ley una codificación de la moral, postura proveniente de los llamados "comunitaristas" (para quienes debe haber mucha dosis de moral en la vida pública), de Ronald Reagan y los “conservadores" en los 80s, y recientemente de Barak Obama (demócrata "moralista").

Sandel se alinea con la segunda postura después de plantear los siguientes interrogantes y responderlos:

a. ¿Basta la libre elección o la autonomía personales, pregonadas por la postura de la razón pública liberal, ajena a los debates morales y religiosos? A lo que Sandel responde que no.

b. ¿Se puede desinteresar el Estado y lo político en general acerca de la pregunta sobre cuándo empieza la vida humana? A lo que Sandel responde igualmente que no.

Concluye Sandel que la neutralidad es irreal e inmoral pues está de por medio quitar la vida humana.

Transcribo, finalmente, las propias palabras conclusivas de Sandel:

"Que Obama dijese que los progresistas deben abrazar una forma de razón pública más abarcadora y más amistosa con la fe refleja un instinto políticamente sensato. También es una buena filosofía política. El intento de desligar los argumentos sobre la justicia y los derechos de los argumentos sobre la vida buena es un error por dos razones: en primer lugar, no siempre se pueden zanjar las cuestiones referentes a la justicia y a los derechos sin resolver cuestiones morales sustantivas; y en segundo lugar, incluso cuando es posible, puede que no sea deseable" (Sandel, 2011, p. 284).

Con todo lo anterior, se ha querido traer a colación un par de temas espinosos para la filosofía del derecho; el fin de ello es para despertar conciencia frente a tales temas (y tantos otros similares por espinosos), ya que hoy parece que la conciencia jurídica es masificadora en unos casos, o dormida en otros, o impuesta también. 


\section{Una acotación personal:}

Preferiría el sistema anglosajón de derecho, que consagra principios y no normas, sentencias judiciales y no preceptos legales; ello para decir que los casos sangrantes, excepcionales, deberían dejarse en manos de la prhónesis, de la prudencia del juez; la ley es una luz general y el caso particular es la encarnación de la persona en el tiempo y el espacio; es la aplicación necesaria para el derecho-ley de la equidad, la cual pesa tanto como la norma; cada una vale el cincuenta por ciento del derecho; no es el hombre para la ley sino la ley para el hombre, es el siempre luminoso y perenne principio de Cristo para la aplicación de la ley; fue el deseo de Tomás Moro en "Utopía" cuando decía que ojalá los ordenamientos jurídicos tuviesen pocas normas; es el "yo soy yo y mis circunstancias" de ORTEGA y GASSET, es decir, lo perenne y lo histórico vistos conjuntamente.

B. LA FAMILIA

"La familia es el núcleo fundamental de la sociedad" (C.P. art. 42, 1991).

[Por cierto, dicha afirmación constitucional es, no lo dudamos, una codificación legal de la moral o, al menos, de una realidad social bastante notoria con tintes éticos; y es ya fundamental y significativo que la familia sea el factor que más alegría y felicidad da, por ejemplo, a los colombianos, según consta en una encuesta del Centro Nacional de Consultoría (2013, mayo 15); esto lo digo de otra parte para aquellos que niegan la relación estrechísima entre derecho y moral, entre derecho y una sociología mínima: por lo menos nuestra Constitución sí consagra el vínculo interno y no puramente exterior, entre derecho y moral, o entre derecho y realidad sociológica; para la muestra este botón].

La familia es referente o fuente del derecho-como la persona humana que acabamos de ver-, de la escuela clásica del derecho natural.

Anteriormente hablamos de la centralidad de la persona para el derecho por ser ambas realidades - persona y derecho- "relacionales", y por ser la persona un ser superior en el orden de la creación (a no ser que haya una matriculación radical en el "sociologismo" extremo, o en el "totalitarismo de Estado"). Podemos plantearnos ahora si otras instancias -en este caso la familia- son capitales para el derecho, esto es, si son referente o fuente de derecho, y sujetos de derechos y deberes. 
¿No afirma la Constitución Política que la familia es la célula básica de la sociedad, el núcleo fundamental de la misma, constituyéndose así en fuente material de derecho? ¿Alrededor de ella no existen innumerables normas jurídicas? ¿Por ser fuente de derechos, no le corresponde a ella en gran medida preservar a la sociedad, ser su núcleo como dice la Carta del 91, siendo ese también su principal deber? ¿Y si es fuente y sujeto de derechos, no corresponden frente a la familia obligaciones de todos para con ella, respetarla precisamente como núcleo de la sociedad?

Del hombre y la mujer nace la especie humana y eso merece todo el respeto y custodia por parte del derecho; de ese hecho tan fundamental y básico nace todo el arco normativo-jurídico que debe darse a esa célula social, esa institución básica de la sociedad. En ese sentido, podría incluso hablarse de un "familiarismo", así como Mounier habla de "personalismo", entendiendo por familiarismo una apuesta radical y decidida por la familia, desde el derecho y desde toda otra instancia social (pero poco se habla de la familia y poco se la defiende con hechos).

Sabemos que es poca la atención social que se le brinda a la familia; si jurídicamente a la familia se le ha tratado de dar cierta protección, no sucede lo mismo por parte de las personas y ciertos grupos sociales en particular: existe una alta irresponsabilidad para mantener la familia como célula social: no existe fidelidad conyugal, no existe responsabilidad paterno-filial; otro tanto acaece con la sociedad, y cuando hablo de la sociedad me refiero más concretamente a los medios de comunicación social, que no la defiende; a la prensa hablada y escrita le cabe mucha responsabilidad en la actual destrucción de la familia; dice la prensa auto-regularse pero no lo hace y menos de cara a la familia; y el Estado de paso la deja a su aire sin exigir responsabilidades a los medios de comunicación social bajo la premisa de que "más vale una prensa desbocada que una prensa censurada", como dijera hace años un Presidente de la República.

Pero ocurre que a la familia también le corresponde su parte de responsabilidad: no existen asociaciones de familias que busquen auto-defenderse ante los ataques de los medios de comunicación, de la publicidad, de la sociedad; ellos se sienten a sus anchas por la no presencia de dichas asociaciones.

Para dimensionar a la familia es menester plantearnos la siguiente cuestión: ¿cuál es el origen de la familia? La Constitución Política de Colombia de 1991 dice que la familia nace de tres fuentes: "Se constituye por vínculos 
naturales o jurídicos, por la decisión libre de un hombre y una mujer de contraer matrimonio o por la voluntad responsable de conformarla.".

Surge de inmediato frente a la norma transcrita el tema actual y debatido del matrimonio de homosexuales. A este respecto parece conducente acudir de nuevo a Michael Sandel (en su libro 'Justicia, ¿hacemos lo que debemos?'), quien a este respecto, en resumen, sostiene:

Existe la posibilidad de reconocer por parte del Estado sólo el matrimonio de heterosexuales; existe la posibilidad de que los homosexuales se casen y ello sea reconocido por el Estado; y existe la posibilidad de que los homosexuales se casen en asociaciones privadas, para las cuales el Estado no interviene.

La tercera posibilidad en realidad de verdad cuenta con pocos seguidores, dice Sandel; pero la primera pierde terreno en aras de la segunda por la creciente avalancha de la tesis de la "razón pública liberal" que hace prevalecer la autonomía particular; empero, ante ella cabe recordar la finalidad del matrimonio y de la familia, de las convicciones éticas.

Transcribo una frase suya sobre esto: "El verdadero meollo del debate del matrimonio gay no es la libertad de elección, sino la cuestión de si las uniones entre personas del mismo sexo merecen que la comunidad las honre y reconozca; es decir, si cumplen el propósito de la institución social del matrimonio. Tal y como diría Aristóteles, de lo que se trata es de la justa distribución de cargos y honores. De lo que se trata es del reconocimiento social" (p. 292). Es pues una cuestión de finalidad social, una cuestión teleológica de fondo. Y, ante tal finalidad, dice Sandel, “....no podemos permanecer neutrales entre concepciones contrapuestas de la vida buena” (p. 294).

El problema es que tal tesis se enfrenta al sociologismo actual según el cual lo que la sociedad diga es lo que debe prevalecer en el derecho; a este respecto, por ejemplo, dice Oscar Collazos: "Si las instituciones del Estado no se adaptan a estos cambios, si no los legitiman (las cursiva son mías) e incluyen en su proyecto democrático, vamos a vivir la experiencia de una sociedad esquizofrénica" (2013, febrero 7); es así una posición típicamente iuspositivista; la ley es solamente un instrumento de regulación social; como dice Sandel frente a lo anterior, no importa el "contenido" de la elección sino que se proteja el derecho a "elegir" (Sandel, 2011, p. 291); pero la simple elección puede acarrear graves consecuencias posteriores impredecibles.

Ante tal situación, vuelve mi propuesta antes mencionada con ocasión del tema del aborto, de establecer en leyes y jurisprudencias de gran impacto social la cláusula de evaluación periódica de esas leyes y jurisprudencias 
para así tomar, si es del caso, medidas frente a las consecuencias negativas de los hechos propiciados por dichas leyes y jurisprudencias.

Desde luego no basta una cláusula de evaluación periódica, es menester que quienes están comprometidos con la presencia moral y religiosa en la sociedad (que no es lo mismo que nexos entre poder político y religioso, cuestión bastante depurada por fortuna en buena parte en Occidente) den ejemplo y testimonio de su posición moral: es decir, no se trata tanto de condenas frente al contrario o frente a leyes y jurisprudencias que no se comparten, en este caso el "laicismo", el "progresismo", etc., sino de sentar un ejemplo de coherencia moral.

Ahora bien, en aras de su derecho a la "diferencia" por parte de los homosexuales, para su unión debe adoptarse otra nomenclatura; en realidad ya se ha hecho cuando se habla de "matrimonio igualitario".

Pues bien, aquí pienso que por razones de la "proveniencia" de todo ser humano al mundo, es decir, por venir todo hombre de espermatozoide masculino y de óvulo femenino, el niño tiene el derecho prevalente (como dice el art. 44 de la Constitución Política colombiana) a padres heterosexuales, y en tal línea, la adopción debe dejarse "preferentemente" para los padres heterosexuales sobre las parejas homosexuales. Sólo en casos extremos debe dejarse tal adopción a los homosexuales.

Desde luego las escogencia de los padres heterosexuales debe ser muy cuidadosa, y, sólo faltando éstos, podrían los niños expósitos, abandonados totalmente, pasar a manos de parejas homosexuales, igualmente escogidos con mucho cuidado a fin de garantizar a los adoptados el derecho a una familia bien constituida: el hijo prevalece frente a los padres.

Y hablando de la familia, no sobra recordar en este momento que ésta se constituye en un "derecho" de los niños tal como aparece en el art. 44 de la Carta Política colombiana de 1991: "Son derechos fundamentales de los niños... tener una familia y no ser separados de ella".

Pero, a su vez, a la familia le obliga velar por ellos tal como también prosigue dicho artículo 44: "La familia, la sociedad y el Estado tienen la obligación de asistir y proteger al niño para garantizar su desarrollo armónico e integral y el ejercicio pleno de sus derechos".

Para terminar estas breves consideraciones sobre este referente material del derecho, leamos unas palabras a título de evaluación de Mijail Gorbachov (pp. 123-124), a propósito de la mujer y la familia: 
"Pero, a través de los años de nuestra difícil y heroica historia, no prestamos atención a los derechos y necesidades específicas de la mujer, que surgen de su papel de madre y ama de casa y su función educativa esencial en lo que respecta a los hijos. Al ocuparse de investigaciones científicas, trabajos en obras de construcción, en producción y en servicios o dedicarse a actividades creativas, a las mujeres no les queda suficiente tiempo como para realizar sus tareas diarias en el hogar: labores domésticas, educación de los hijos y el logro de una buena atmósfera familiar. Hemos descubierto que muchos de nuestros problemas, en la conducta de los niños y de los jóvenes, en nuestra moral, cultura y producción, en cierta forma derivan del debilitamiento de los vínculos familiares y de una actitud indolente hacia las responsabilidades familiares...".

Parecieran palabras de metafísicos, de religiosos, de moralistas, pero no, provienen de un comunista a finales de los años 80s del pasado siglo: ¿no dejan entrever allí, que hay cosas esenciales al ser humano, y que no todo es cambio, sobresalto e incertidumbre? ¿No serían una invitación a aunar lo perenne con lo cambiante?

\section{LA SOCIEDAD}

"Si los cambios en nuestras costumbres morales no son legitimados por la institucionalidad, se harán inexorablemente a pesar de ella"

(Oscar Collazos).

La sociedad es la fuente por antonomasia del derecho según el sociologismo jurídico.

Hablar de la sociedad como fuente del derecho es afrontar el tema del sociologismo; éste surge en el siglo XIX; se debió principalmente al auge de la ciudad moderna, al urbanismo, al desplazamiento de la ruralidad, a la creciente publicación de libros, y a la aparición de los medios de comunicación social. Sus padres fueron principalmente Augusto Comte, Emile Durkheim, Karl Marx...

Podemos valernos para reflexionar este tema de un artículo de Oscar Collazos aparecido en El Tiempo (Bogotá), el día 7 de febrero de 2013, donde aparece de cuerpo entero la prelación de la sociedad frente a toda otra realidad; me parece que ahí queda retratada en buena parte la postura sociologista. 
Dice Collazos que la libertad no debe ser algo que se maneje desde el poder político, desde la institucionalidad, desde los moralismos, desde las leyes, sino que es una conquista de los ciudadanos.

Leámoslo: "Consuela saber que las sociedades se mueven y cambian..., a pesar, incluso, de las leyes que pretenden detener los cambios sociales y de costumbres. Los sistemas de censura y prohibición no bastan para frenar las corrientes impetuosas de las sociedades".

Se deduce de ahí que la sociedad tiene prelación, que las leyes no son sino expresión de la sociedad; la ley no es antecesora y guía de la sociedad sino expresión de ésta; no habría leyes inspiradas en la naturaleza, en un algo objetivo y estático, pre-existente al legislador, sino que la ley obedece al dinamismo cambiante de la sociedad; la ley, reconoce los hechos sociales y máximo los regula normativamente y debería propiciar elementos educativos; la ley no debe ser primariamente coercitiva sino educativa (claro que en este punto hay una cierta coincidencia con Tomás de Aquino). El derecho disciplinario, coactivo, autoritario, debería ceder ante un derecho educativo; dice Foucault (p. 18): "Si el sistema del derecho está centrado en el rey, es necesario eliminar la dominación y sus consecuencias"); es lo que vemos que sucede con el tema de la despenalización del aborto, o de la despenalización de la dosis mínima de drogas sicotrópicas, o de la legalización del matrimonio de homosexuales, etc.; existe el aborto en la sociedad, existe el consumo de drogas ilícitas en la sociedad, existen las uniones de homosexuales en la sociedad, etc.; es un problema, mejor, una "realidad social", dicen los sociologistas; entonces todo ello debe regularse por la ley que es expresión de todos esos fenómenos sociales: jes el puro iuspositivismo!

Empero, el problema radica en saber "hasta dónde" se puede ir en materia legal, cuáles son los límites legales de las conductas humanas, cuál debe ser el cauce a seguir cuando se legaliza una conducta hasta un momento determinado tenida como ilícita, $\mathrm{y}$, políticamente, hasta dónde llega la democracia.

A este respecto las posturas están divididas.

Por ejemplo, en una orilla encontramos a Joseph Ratzinger cuando sostiene que la democracia tiene presupuestos pre-estatales; ella -la democracia-, sigue diciendo Ratzinger, es valiosa en sí misma por muchos aspectos, aunque no siempre posee la razón, como en los procesos legales de Sócrates, de Jesús, o en el tratamiento a los judíos en tiempos del nacionalsocialismo 
condenados a la muerte por la mayoría, pero que no por eso fueron condenas legítimas; ello es razón por la que las personas deben estar alertas, con los ojos despiertos, frente a las mayorías.

En la otra orilla de esta cuestión encontramos entre otros al filósofo del derecho norteamericano Richard Rorty para quien la democracia -la mayoría- es la última palabra para la validez de la ley, reduciéndose así al unilateralismo del número (Ratzinger, 2005, pp. 92 y ss).

De esta manera volvemos a lo ya dicho: ¿debemos caer en unilateralismos cerrados? ¿No es más sano, aunar lo perenne y lo accidental, lo sustancial y lo pasajero, en una armonía del punto medio, difícil pero posible en multitud de casos?

Finalmente, a pesar del peso de la sociedad en la vida de las personas, del mundo moderno veloz, del derecho sociologista, el mundo personal, la conciencia estudiosa siempre debe quedar a salvo dentro de un marco de equilibrio: para salvaguardar la personalidad se cuenta con ese gran invento democrático moderno de la "objeción de conciencia", personal, e incluso institucional, frente a sentencias y jurisprudencias mayoritarias; es la salvaguarda del antiguo postulado aristotélico -y, en ese momento y para siempre novedoso principio de Cristo-: no es el hombre para la ley, para el sábado, (la jurisprudencia, la mayoría) sino la ley para el hombre; desde luego el bien del hombre, no su capricho.

D.

\section{LA NATURALEZA}

"El hombre no se crea a sí mismo. Es espíritu y voluntad, pero también naturaleza"

(Benedicto XVI).

La naturaleza es fuente excepcional del derecho según la escuela del derecho natural, junto con la persona y la familia, como ya se ha anotado.

¿Es la naturaleza "fuente" material del derecho? ¿De "qué naturaleza” hablamos?

Por naturaleza entendemos esencialmente dos cosas: a) la physis, el cosmos, el universo físico; y b) lo más esencial al hombre, lo que lo hace ser hombre y no otro ser, es decir, su razón, su voluntad, su libertad, su afectividad, su especial corporeidad, en una palabra su espíritu encarnado; Mounier habla de "existencia incorporada" (Mounier, 2001, p. 37). 
Tanto la naturaleza física, como la naturaleza humana, son fuente material del derecho, pues de ellas se desprenden normas que vinculan a los hombres, de proveniencia de la autoridad, normalmente estatal o supraestatal, coactivas, y sancionatorias visiblemente.

En los tiempos que corren, la "naturaleza física" es fuente para el derecho en lo que concierne a los derechos humanos y más concretamente a los llamados "derechos al medio ambiente" (físico), (y si fuente del derecho, ella, la naturaleza, también es sujeto de derechos, incluidos los derechos de los animales, en virtud de la "complejidad del universo" que nos hace interdependientes unos de otros, aunque no de deberes por ser inanimados).

Sin embargo, en materia de derechos humanos en sí mismos, la "naturaleza humana" no corre la misma suerte en todos los casos: por ejemplo, en materia de aborto, no hay claridad en todos los espíritus si el feto es "hombre" antes de los tres meses; y en realidad, desde hace siglos, el "derecho a la libertad" prima sobre "lo natural en sí mismo" del ser humano.

Podríamos remontar ese proceso libertario a Guillermo de Ockham en el siglo XIV con su primacía de los "derechos subjetivos" sobre "lo justo en sí" (propio de la edad media), pasando por Lutero en el campo religioso, quien hace primar la libre interpretación de las Escrituras Sagradas sobre la interpretación por autoridad del Magisterio de la Iglesia, prosiguiendo con el dogma de Descartes, "pienso, luego existo" en filosofía, donde se da prelación al acto de pensar sobre la "res en sí misma considerada" (la cosa en sí misma, objetiva, real), siguiendo con las Declaraciones de derechos por las revoluciones políticas liberales (no de deberes) de los siglos XVII y XVIII, pasando por Kant en el mismo siglo XVIII con su filosofía individualista, separadora de los hechos respecto de los valores, divorciadora del noumeno (idea) respecto del fainomenon (lo que aparece), hasta llegar al siglo XX tan sensible a la libertad, victoriosa ante los totalitarismos de Estado.

Así las cosas, son más de 6 siglos de evolución hacia el subjetivismo más acendrado, tanto en la filosofía como en los espíritus en general, que hace muy difícil en la actualidad, por no decir imposible, la aceptación de valores "en sí”; sólo se aceptan hoy los valores "en mí".

Lo grave y riesgoso de este proceso es su pendularidad histórica, es decir, que llegue a extremar de tal manera a los espíritus en general que haga pensar en la posibilidad o incluso en la necesidad de un "nuevo totalitarismo del Estado" (o como llegue a llamarse su sucedáneo) para controlar los excesos del libertarismo. 
Ahora bien, más específicamente en filosofía general y en filosofía del derecho en particular, la discusión sobre la importancia de la "natura" para el derecho gira en torno a lo que se ha denominado la "falacia naturalista", siendo éste uno de los problemas más acuciantes de la filosofía moral y jurídica del presente (así lo considera por ejemplo, Mauricio Beuchot Puente en su obra 'Filosofía del derecho, hermenéutica y analogía'; Francesco D'Agostino también lo incluye dentro de los temas centrales de la filosofía del derecho actual en su libro Filosofía del derecho).

¿Qué es la falacia naturalista?

Desde luego es un tema ampliamente debatido, lleno de filigranas teóricas muy importantes; aquí me limitaré a sintetizar el tema.

El problema se remonta a David Hume, en el siglo XVIII, quien critica a tratadistas de moral y de filosofía del derecho cuando "atan el ser al deber ser" (a simple vista todo pareciera indicar que el ser y el deber ser son dos cosas totalmente distintas pues, en efecto, una cosa es ser (naturaleza) y otra el deber ser (razón humana autónoma); una cosa es estar siendo en la realidad, y otra llegar a ser por medio de la razón humana; sin embargo, el tema se traslada específicamente al campo de lo normativo, donde el lenguaje trata del llegar a ser (deber ser), de una "aspiración" del espíritu humano a "superar" los fenómenos, a través de preceptos: si alguien comete tal conducta, debe ser castigado, etc., de donde se deduce que las cosas aún no son, sino que deben llegar a ser).

¿Dónde se asienta ese deber ser? ¿Se asienta, dicen Hume y sus seguidores positivistas, en la "voluntad" del que hace la norma? Esta última pregunta se responde con un rotundo "sí"; todo radica en un "voluntarismo" del legislador -y del hombre en general-, y no en algo "real", objetivo, exterior, pre-establecido heterónomamente.

Propiamente el término "falacia naturalista" (léase mentira de lo natural, de la naturaleza en el campo normativo moral y jurídico) se debe al filósofo analítico George Edward Moore, quien no veía cosas naturales en el hombre, como por ejemplo cuando decía que la bondad humana no es natural (¿un eco de Hobbes quien consideraba al hombre como lobo para los demás hombres?) sino quizá una "mera intuición" pero no con estatuto en lo natural (o naturaleza del hombre), y añadiendo que lo bueno es indefinible.

Esta posición de separar el ser del deber ser, ya había sido sostenida antes por Kant cuando separó los "hechos" de los "valores", el "noumeno" del 
"fainomenon", el pensamiento de la naturaleza; Kant como sabemos es idealista, para él sólo valen las ideas, no la naturaleza de las cosas.

En esa línea separatista del ser respecto del deber ser, también se encuentra Max Weber quien reduce todo a "cultura" (desdeñando lo natural), y, Hans Kelsen [Joseph Ratzinger responsabiliza muy en concreto a Kelsen en este proceso de separar el ser del deber; dice Ratzinger que "antes" de Kelsen era más o menos alcanzable saber qué era lo justo, pues la justicia se basaba en la armonía de razón y naturaleza, sustentadas ambas en un Spiritus Creator; pero, “después" de Kelsen, la naturaleza y la razón se divorciaron y todo quedó circunscrito a la razón, a la mera lógica racional, cayéndose en el puro subjetivismo, y así, poder alcanzar la justicia se hizo muy "cuesta arriba"; empero Ratzinger da un parte de esperanza con el renacimiento de la naturaleza por parte de los “movimientos ecologistas" (Benedicto XVI, 2011).

Contrarios a esa separación entre ser y deber ser, entre naturaleza y razón, entre natura y libertad, se encuentra otro bando de filósofos: Kalinowski, Finnis, Moulines, Beuchot, Dewey, de la Torre Rangel, Massini, etc., quienes consideran que entre el ser y el deber ser no existe ruptura radical.

Así por ejemplo se dice que el deber ser de la conclusión en un silogismo está necesariamente precedido de una premisa que lo incluye; o se dice que en el lenguaje ordinario, en la praxis, en la vida ordinaria, siempre hay un ligamen entre el hecho y su valoración, entre la prescripción y la descripción, entre lo que sucede y la norma, en definitiva entre el ser y deber ser, entre la naturaleza y la razón.

Ese ligamen entre ser y deber ser se ve cuando uno observa un accidente (hecho), y, enseguida, se afirma: "no pudo ser" (deber ser). Y es que la naturaleza está como mandando señales de deber ser continuamente: fumo (hecho), pero no debe ser así pues daña a la naturaleza [sobre el tema de la falacia naturalista se puede consultar más en detalle la obra de Mauricio Beuchot Puente, Filosofia del derecho, hermenéutica y analogía, ya citada, pp. 119-125, y Filosofía del derecho, de Francesco D’Agostino, también arriba citada, pp. 73-84].

En últimas, entonces, se trata no tanto de privilegiar a uno de estos dos polos en desmedro del otro, idolatrar sólo la libertad o idolatrar sólo la naturaleza, sino de armonizar en un punto medio naturaleza y libertad: una libertad a espaldas de la naturaleza, la maltrata a ésta y las consecuencias negativas no se harán esperar (lo vemos en el campo medioambiental de una 
manera palpable); pero la naturaleza necesita a su turno de la proactividad de la libertad y la razón para transformar a aquélla dentro de los límites de la ética y el derecho: es el papel de la bioética y del bio-derecho hoy por hoy.

E. EL ESTADO

"Salus populi suprema lex"

(J. Locke).

Esta frase se remonta a la antigüedad:

Cicerón.

El Estado es referente o fuente material del derecho según el estatismo (vgr. para Hegel). Y es referente y fuente material del derecho, también, según el iuspositivismo.

Que el Estado es referente, "fuente" material del derecho -del derecho positivo concretamente como fuente formal, a su vez-no parece admitir dudas.

El Estado como ente natural y cultural produce, origina, genera normas.

Empecemos por hacer una "aclaración" que creemos conveniente:

No se trata de "confundir" al "productor" de normas -al Estado, que aquí se contempla como fuente material del derecho-, con su "producto", es decir, el derecho positivo; el Estado es "fuente" material del derecho; pero su producto, las leyes, las sentencias, el derecho positivo en general, son las llamadas "fuentes formales" del derecho; éstas últimas no son el objeto principal de estas reflexiones sino de otras áreas de estudio jurídico como la Teoría General del Derecho.

Aquí no veremos al Estado en cuanto a su producto, esto es, el derecho positivo, sino en cuanto productor del derecho; veamos el asunto en tres aspectos:

a. En primer lugar, el Estado no solamente genera normas sino que también es "sujeto" de derechos (es delito, vgr. traicionar a la patria, aunque ciertamente Estado y Patria no son exactamente lo mismo; el Estado es la organización visible de lo político a través de varias instituciones, y la patria es el territorio donde han nacido los padres y uno mismo, habiendo una razón de afectos vinculantes con ella; vgr. es delito la rebelión contra el Estado; vgr. es delito cometer desfalcos contra el Estado, etc.). 
Y el Estado es además, sujeto de obligaciones: el Estado tiene fines que cumplir: servir a la comunidad, promover la prosperidad general, garantizar la efectividad de los principios, derechos y deberes consagrados en la Constitución, facilitar la participación de todos en las decisiones que los afectan, defender la independencia nacional, mantener la integridad territorial, asegurar la convivencia pacífica, asegurar el orden justo: art. 2 de la Constitución Política.

El Estado, además de las anteriores obligaciones, reconoce, sin discriminación alguna, los derechos inalienables de la persona y ampara a la familia como institución básica de la sociedad: art. 5 de la C.P.

También es obligación del Estado reconocer y proteger la diversidad étnica y cultural de la nación colombiana: art. 7 de la C.P.

Finalmente, el Estado tiene por obligación proteger las riquezas culturales y naturales de la Nación: art. 8 de la C.P.

Estas son las que hemos denominado condiciones en que aparece el Estado frente al derecho.

b. ¿El Estado parece que tiene más obligaciones que derechos? Sí, pues el Estado debe ser y estar limitado en su poder; el poder es una realidad humana y política muy grande; el Estado es una de las organizaciones que más poder tienen, $\mathrm{y}$, porque éste puede y tiende a desbocarse, es menester controlarlo, control que se opera, entre muchos mecanismos posibles, mediante la imposición de deberes, responsabilidades y obligaciones del Estado.

Este es un asunto central en esta reflexión, el del poder del Estado, como que en él se concentra un rasgo del Estado mismo que marca su ser como generador de derecho y como sujeto de derechos y de obligaciones. Es un tema de límites del Estado en su quehacer jurídico.

Para controlar ese poder gigantesco del Estado se encuentra el derecho.

En efecto, el derecho y el Estado siempre han ido ligados; no se entiende el uno sin el otro. Ya Platón decía que la ley es hecha por el Legislador gobernante del Estado, Nomothetes ('Leyes', Beuchot, 2006a, p. 20); y Aristóteles dice que la justicia distributiva (un tipo de derecho, diríamos en lenguaje de hoy) está a cargo del Estado, quien reparte bienes, cargas y obligaciones (Beuchot, 2006b, p. 24). 
Hasta ahí aparece el Estado como "generador" de normas jurídicas.

Pero ese Estado generador de normas jurídicas debe ir también ligado al derecho. Es una sana paradoja del Estado: él "genera" y produce normas, pero al mismo tiempo está "controlado" por normas, bien sean ellas superiores al Estado, o bien sean producidas por el mismo Estado.

La adscripción al primer derecho, esto es, el derecho positivo, es la postura del llamado "Estado de derecho", desarrollada en el siglo XIX (KAUFMANN, 2002, p. 74); y la adscripción al derecho natural, y al derecho positivo también, es propia de la postura del iusnaturalismo (así lo veía CiCERóN, por ejemplo).

Es tanto como decir que el Estado no es un "absoluto", no es un ente totalmente independiente, sino que debe estar inter-relacionado con la juridicidad; ¿por qué esa inter-relación? La respuesta parece obvia: para que el Estado no se extralimite, y ello debido al poder tan grande que posee, tal como se acaba de recordar.

Si es limitado por el derecho positivo equivale a decir que el Estado se auto-regula, él produce normas pero esas normas son para su autocontrol; y si es limitado por el derecho natural equivale a decir que el Estado tiene una regulación que lo antecede, hay algo previo y superior al Estado mismo, inscrito en la naturaleza del hombre, que el hombre es anterior al Estado y éste no puede tiranizarlo.

Y... ¿Quién controla más al Estado? ¿El propio Estado mediante su regulación "autónoma", o, mediante la regulación "heterónoma" de la naturaleza de las cosas?

A nuestro juicio lo controla más la regulación heterónoma; al fin y al cabo la auto-regulación por parte del propio Estado tiene un grado de voluntariedad propia, más que de objetividad por parte de los gobernantes: ¿No decían los criminales de guerra nazis que ellos no eran culpables ya que actuaban bajo un Estado de derecho, bajo una legalidad precisamente nazi? Pero, frente a lo anterior, ¿no juzgó el Tribunal de Nuremberg que justamente eso no era argumento ya que por encima de la legalidad está la ética, el derecho universal, la humanidad?

Lo contrario a esa adscripción al derecho (sobre todo del derecho universal) es la postura del "totalitarismo de Estado", donde el Estado es un todo absoluto, un dios terrenal, un leviatán.

Los límites al Estado no existen en esta postura totalitarista; nada lo trasciende. Todo dentro del Estado, nada fuera del Estado, nada en contra 
del Estado. Esto quiere decir más exactamente que para el totalitarismo la ley es enteramente una realidad al servicio del Estado y por encima de la persona humana: ley y persona están al servicio enteramente del Estado. Tal fue la postura de los totalitarismos de Estado "comunista" (como la Unión Soviética de 1917 hasta 1989) y de los totalitarismos de Estado "fascista" (Mussolini, 1922-1945) y "nacionalsocialista" (Hitler, 1929-1945).

La única ley, entonces para el totalitarismo estatal, es la ley positiva al servicio enteramente del Estado y con marginación o desplazamiento de la persona humana. Para el totalitarismo de Estado es todavía más impensable una ley natural que lo anteceda; el Estado se convierte en una creación meramente cultural, ideológica, política.

La superación de los totalitarismos estatales es uno de los grandes logros de la democracia liberal y constitucional post-absolutista y posttotalitarista: para las democracias liberales e individualistas (individualismo bien entendido, donde existe la autonomía individual en sano equilibrio con lo público; no como nos lo inventamos, o mejor, aplicamos, en las republiquillas latinoamericanas, donde por individualismo se entiende hacer lo que se le da la gana a cada quien sin ninguna consideración de lo público), lo primero es la persona, la ley, el bien común, y el Estado está al servicio de ellas; para la democracia liberal si el Estado no tiene esos límites, es decir, la persona, la ley, el bien común, el Estado, se torna en arbitrario, despótico, tiránico.

La posición constitucional colombiana es justamente esta del límite estatal: por eso dice el texto constitucional que Colombia es un "Estado social de derecho", fundado en el "respeto de la dignidad humana", en el trabajo, en la solidaridad de las personas que la integran y en la prevalencia del interés general (Const. Colombia, art. 1, 199). Y en esa misma línea se encuentra el artículo 94 de la Carta que señala que los derechos humanos no son únicamente los enunciados en el texto constitucional sino también todos aquellos que sean "inherentes" a la persona humana; igualmente en esa línea se encuentra el art. 230 de la Constitución cuando después de decir que los jueces se rigen por las leyes para juzgar, a continuación se dice que son fuentes auxiliares de la ley, la equidad, la jurisprudencia, los principios generales del derecho y la doctrina.

c. Cercano al concepto de Estado de derecho se encuentra el de "legitimidad del Estado". No son conceptos iguales; el concepto de legitimidad es de carácter mucho más amplio, de un alto contenido ético. El Estado de derecho a lo sumo es una parcela de la legitimidad. 
Pero no lo absorbe, pues como veíamos, el Estado -por ejemplo el nazi- puede llegar a no ser legítimo.

Que el Estado de derecho mire a la persona humana y a lo que se ha denominado en teoría política clásica el "bien común" (o interés general como dice nuestra Constitución de 1991, aunque en otras ocasiones sí habla expresamente de bien común como en el artículo 333), es lo que da lugar a la "legitimidad" del Estado, junto con un Estado de derecho; y dicha legitimidad del Estado, a su turno, contribuye en buena medida a la llamada "validez del derecho", y ambas originan, luego, la "eficacia" del mismo en la sociedad.

Es una tríada importantísima-legitimidad del Estado, validez del derecho y eficacia social del mismo-, considerada como uno de los "temas" más relevantes de la filosofía del derecho de todos los tiempos (debe añadirse, que este tema contiene, de contera, ese otro gran tema de la relación connatural entre derecho y moral; precisamente en este tema se ve la innegable vinculación intrínseca -negada por autores como Kelsen, el primer Kelsen de 1934- de derecho y moral; no es que sean idénticas ambas cosas, pero se necesitan recíprocamente a nivel interno; no es una simple vinculación extrínseca, como de compañeros paralelos de camino; no, es una amistad íntima de las dos realidades).

Por eso se ha dicho, creemos que con claridad y acierto, lo siguiente: "La comunidad política nace, pues, para buscar el bien común, en el que encuentra su justificación plena y su sentido y del que deriva su legitimidad primigenia y propia... Síguese también que el ejercicio de la autoridad política, así en la comunidad en cuanto tal como en las instituciones representativas, debe realizarse siempre dentro de los límites del orden moral para procurar el bien común -concebido dinámicamente-según el orden jurídico legítimamente establecido o por establecer. Es entonces cuando los ciudadanos están obligados en conciencia a obedecer" (Concilio Vaticano, 1962,1965); nuevamente se ve en la anterior cita la tríada en un orden secuencial: legitimidad del Estado, validez del derecho y eficacia social del mismo.

Es un trípode, decíamos, inseparable y ordenado, que se puede traducir también como manifestaciones éticas o legítimas del Estado, del derecho y de la sociedad; al primero le corresponde la legitimidad; pero, en tanto busque el bien común en su derecho produce la validez del mismo como elemento integrante del bien común, $\mathrm{y}$, produciendo, en consecuencia, un ulterior resultado: la eficacia en sociedad del mismo.

Es la conclusión a la que llegan Oscar Mejía Quintana y Natalia Encinales Ariza (2011, p. 70) cuando afirman: 
"La consideración monodisciplinaria sobre cada una de las problemáticas específicas de la filosofía práctica, legitimidad, validez y eficacia, ha disgregado la estrecha relación ontológica y epistemológica que entre ellas existe: el problema de la legitimidad visto desde la esfera filosófica y política; la validez desde la esfera jurídica y la eficacia sólo desde la esfera sociológica y socio-jurídica.

Empero, los desarrollos no sólo actuales sino incluso clásicos de estas problemáticas muestran lo errado de tales consideraciones aisladas".

Digamos algo más sobre la legitimidad del Estado: ¿cuándo un Estado es legítimo?

Ya hemos dicho que esa legitimidad se da cuando respeta a la persona y al bien común, y que parte de dicha legitimidad radica también en la validez de su derecho positivo: tanto formalmente como en su contenido material; pero no sólo es esto; la legitimidad del Estado depende también de su constitución primera.

Así las cosas, la constitución o configuración del Estado debe ser legítima, es decir, que aspire a responder al bien común, que busque respetar a la persona humana, que pretenda propiciar el desarrollo político, que sea expresión de una teoría política reconocida, que tenga un instrumento político-jurídico idóneo; en una palabra, debe tener un alto contenido ético-político; éste puede verse por ejemplo con la adopción del republicanismo, o de una monarquía constitucional, o de una democracia, con una Constitución Política que responda en principio o formalmente y en las intenciones a la "salus populi suprema lex" como diría John Locke (2006a)

¿Y qué pasa con los Estados configurados como producto de una revolución armada? A este respecto cabe decir que la llegada al poder también puede ser legítima (vgr. el derrocamiento de Fulgencio Batista por Fidel Castro en 1959); es legítima si obedece a causa graves.

Ya Tomás de Aquino en el siglo XIII, por ejemplo, ponía como causas graves que justificaban el derrocamiento armado del poder establecido el que hubiera una tiranía, que ésta fuera prolongada, que se hubiesen agotado las vías legales, que las propuestas de la subversión fueras superiores a las del tirano, y que las posibilidades de triunfo de los sublevados fueran reales.

John Locke, siguiendo esa tradición, también admite en su teoría filosóficopolítica que un gobierno estatal pueda ser derrocado por causas graves: que el poder legislativo se descomponga, el mal uso del poder, el entregar al 
pueblo a la sujeción de un poder extranjero, que el poder ejecutivo descuide y abandone el cargo, y similares causas (Locke, 2006b).

Ahora, no basta la llegada al poder político, éste debe ser ejercido con el paso del tiempo dentro de los parámetros del bien común: leyes justas, economía justa, pulcritud de la conducta de los funcionarios públicos, derechos y libertades mínimas...

Como se ve, en últimas es una cuestión de ética, no sólo de "ética pensada" sino ante todo de "ética vivida", en lenguaje de Adela Cortina (2000, p. 28). $Y$ es que el piso de toda actividad humana, el más fuerte piso del hombre, la plataforma más seria de los humanos, donde se asientan todas las teorías y esquemas e ideologías, es la "ética vivida"; la ética debe estar en todo y para todo, no sólo la ética pensada sino la ética aplicada, vivida, encarnada; así lo entrevió con toda claridad Aristóteles: la ética es la plataforma de la política; su célebre obra, "Ética a Nicómaco", termina en su última página diciendo: "continuemos", enlazando con su otro célebre libro, "Política". No hay solución de continuidad entre ética y política.

De la legitimidad del Estado en su "origen" y “ejercicio", viene entonces y repitiendo lo ya dicho, el otro elemento, en buena medida, del bien común legitimante del Estado, esto es, la validez del derecho, y su eficacia social; un Estado sin legitimidad en su origen y ejercicio es como empezar mal un trayecto; claro está que el derecho puede a su turno legitimar al Estado en parte, pero de la legitimidad del Estado depende en buena parte la validez o legitimidad, a su vez, del derecho, pues ellos son elementos inseparables, y, como se dijo, de los cuales deriva en buena medida la eficacia social del derecho.

El abordaje que hace la iusfilosofía de este tema es, a fortiori, "filosóficamente"; ¿Qué quiere decirse con ello? Que cada uno de esos ítems, es decir, legitimidad del Estado (tema tratado por la filosofía política), validez del derecho (tema tratado por la Teoría del Derecho), y eficacia del mismo en la sociedad (tema tratado por la sociología del derecho), se abordan desde orillas diferentes, pero la iusfilosofía a su turno los aborda filosóficamente, es decir, los "reúne" de manera "conjunta", "universal", "entrelazadamente"; así lo afirma por ejemplo el iusfilósofo Oscar Mejía Quintana con atino filosófico (2011a, p. 73); y así lo sostiene también Natalia Encinales al afirmar: “...la filosofía aborda la complejidad intra y suprasistemática del ordenamiento jurídico ofreciendo una visión totalizante de la relación legitimidad, validez, 
eficacia del fenómeno jurídico y asumiendo como foco central de su reflexión la norma básica" (2011b, p. 173).

Es por consiguiente un abordaje -estamos circunscribiéndonos sólo a un tema punzante de la iusfilosofía, el de la legitimidad, la validez y la eficaciauniversal, conjunto, filosófico; la legitimidad del Estado, en su origen y en su ejercicio, tiene entre sus componentes, el de producir en parte un derecho válido, y al estar unidas las dos cosas, se produce, también en parte, una eficacia social del derecho.

No podría ser distinto, pues la filosofía es ciencia de lo universal: "Lo primero que ocurriría decir fuera definir la filosofía como conocimiento del Universo" (Ortega \& Gasset, 2007, p. 73); y sigue diciendo Ortega: “¿De dónde viene -se preguntará- este apetito del Universo, de integridad del mundo que es raíz de la filosofía? Sencillamente, ese apetito que parece peculiar a la filosofía es la actitud nativa y espontánea de nuestra mente en la vida. Confusa o claramente, al vivir, vivimos hacia un mundo en derredor que sentimos o presentimos completo" (p. 76).

Queda entonces así expuesta, de paso, una actitud central iusfilosófica: la actitud antes vista de Mejía y Encinales, la actitud no fragmentaria de la realidad y concretamente de la realidad jurídica, la actitud universalista ante la misma, la actitud de integración de todas las cosas del mundo del derecho; y más aún, en el caso de un tema recurrente en la iusfilosofía, el de la legitimidad del Estado, el de la validez del derecho, y el de la eficacia social del mismo; los tres inter-relacionadamente; ¿En ese orden? Pareciera que sí: no habría, en parte, validez del derecho, si el Estado no es legítimo; y si ambos son legítimos, es decir, si Estado y Derecho son legítimos, se desprende, por consiguiente, más fácilmente la eficacia social del mismo.

Pero bien podríamos cambiar ese orden trifásico al afirmar que un derecho válido en sí mismo, al mismo tiempo produce, en parte, legitimidad del Estado, así como la eficacia social del derecho también legitima en parte al Estado. Los tres componentes de la realidad política, jurídica y social, se vinculan, en últimas, inseparablemente.

Lo anterior es para decir que la filosofía, y la iusfilosofía como parte de aquélla, se ocupa de lo universal, tal como lo hacía ver Ortega y Gasset.

En síntesis: el Estado es fuente material del derecho si aquél es legítimo, es decir, si es ético y jurídico al mismo tiempo en el más amplio sentido de esos conceptos, si el Estado se origina y se ejercita dentro de los cánones de 
la eticidad y la legalidad, si el Estado, por lo anterior, produce una validez intrínseca del Derecho ocasionando a la vez su eficacia en la sociedad.

F. CONCLUSIONES AL TEMA DE LOS REFERENTES MATERIALES DEL DERECHO

"Que la virtud moral es una posición intermedia, y de qué manera, o sea que es un término medio entre dos vicios, uno por exceso, otro por defecto, y que es tal porque apunta al término medio en las pasiones y en las acciones, todo esto queda suficientemente declarado. Por esto, ser virtuoso es toda una obra. Alcanzar el término medio en cada caso es una faena... Dar en el medio es extremadamente dificil..."

(Aristóteles)

Llegados aquí, podemos decir que la persona humana, la familia, la sociedad, la naturaleza y el Estado, son los principales referentes materiales del derecho, que deben mirarse conjuntamente, en equipo, a la hora de enjuiciar el derecho.

Esa mirada conjunta creemos que da una visión más completa, equilibrada, y no fragmentaria de los referentes materiales del derecho (las fuentes del derecho llamadas "formales", tal como ya dijimos, no las tratamos aquí por tratarse de un capítulo de la Teoría del derecho, que posee otra naturaleza y otros fines, aunque no son ajenas a los referentes materiales tratados).

Si se reducen los referentes materiales "exclusivamente" a la persona humana, se corre el riesgo de caer en el "individualismo" (a excepción del personalismo de Mounier que considera a la persona como ser esencialmente comunicativo y solidario; ya dijimos también que para nosotros la persona es no solo comunicativa sino también soledad).

$\mathrm{Si}$ se reduce el derecho "exclusivamente" a la sociedad se corre el riesgo de caer en el sociologismo a ultranza.

Si se reduce el derecho "exclusivamente" al Estado se corre el riesgo de caer en el "totalitarismo de Estado".

Si se reduce el derecho "exclusivamente" a la naturaleza se corre el riesgo de caer en un derecho no proactivo, pasivo, frente a ella [es lo que Amartya Sen llama el puro "estado de naturaleza", lo cual es profundamente defectuoso, dice (p. 278). 
Tener en cuenta todas esas fuentes de manera armónica, equilibrada, es tarea difícil, muy difícil como dice el estagirita según su frase arriba anotada al iniciar este acápite, pero, como es una aspiración elevada, verdaderamente humana, perfectamente jurídica, vale la pena luchar por ella para tratar de lograr el denominado bien común, esencia de la legitimidad del Estado, de la validez del derecho, y de su eficacia social.

Los agentes u operadores del derecho deben luchar por este ideal.

Así, los juristas deben recurrir al arsenal de argumentos que apoyen la justicia que persiguen (a este respecto remitimos de manera muy particular a la llamada Teoría de la argumentación jurídica, tratada en el capítulo referente a la tercera vía iusfilosófica): entre más y mejores argumentos, entonces, se llega más probablemente a la justicia por parte de los juristas litigantes. Y sobre todo puede acudir a la teoría de la hermenéutica jurídica, que busca el equilibrio entre sujeto y objeto, entre operador del derecho (juez, litigante, legislador) y ley (universal y local).

De igual manera, los jueces deben buscar ese punto de equilibrio mediante la prudencia; desde siempre el derecho ha tenido que ver con esta virtud, llamada por algunos auriga virtutum, esto es, cabeza de las virtudes, virtud cardinal por excelencia: "La virtud es, por tanto, un hábito selectivo, consistente en una posición intermedia para nosotros, determinada por la razón y tal como la determinaría el hombre prudente" (Aristóteles, 1981, p. 23); pero... ¿qué es, además, la prudencia? Sigamos leyendo al propio Aristóteles: "Lo propio del prudente parece ser el poder deliberar acertadamente sobre las cosas buenas y provechosas para él, no parcialmente, como cuáles son buenas para la salud o el vigor corporal, sino cuáles son para el bien vivir en general... Y así, podría decirse en general que el prudente es el que saber deliberar" (p. 76).

Respecto de la prudencia siempre podemos acudir a unas páginas de Thomas Hobbes que consideramos en línea con las de Aristóteles y que se refieren directamente al juez:

"Las cosas que hacen de alguien un buen juez o un buen intérprete de las leyes son, en primer lugar, un recto entendimiento de esa ley natural básica llamada equidad, que (no dependiendo de la lectura de los escritos de otros hombres sino de la bondad existente en la propia razón natural de un hombre y en su meditación) se supone máximemente presente en quienes han tenido más ocio y más inclinación a meditar sobre el tema” (Hobbes, 2007, p. 246). ¡Hermosas y sabias palabras! 
Por último, el operador del derecho denominado el Legislador debe acudir a las modernas teorías de la legislación (Kaufmann, 2002a, pp. 54 y ss). Leamos al propio Kaufmann sobre este punto: "La idea de derecho (deber ser) y los principios que de ella emanan (por ejemplo, suum cuique tribuere, neminem laede, pacta sunt servanda, la regla de oro, el imperativo categórico, el principio de equidad, el principio de responsabilidad, el mandamiento de tolerancia...) y las situaciones fácticas vitales (ser) intelectualmente anticipadas por el legislador para su posible regulación, tienen que elaborarse conjuntamente en un proceso interrelacionado, de tal manera que se 'correspondan' recíprocamente" (2002b, p. 56); y termina diciendo Kaufmann: "La teoría de la legislación es una ciencia de verdad multidisciplinaria" (2002c, p. 57); como se ve, aquí también se hace un llamado a la armonía, al conjunto, al trabajar en equipo, al punto medio. 


\section{LA JUSTICIA COMO FIN DEL DERECHO}

"Lo que nos mueve, con razón suficiente, no es la percepción de que el mundo no es justo del todo, lo cual pocos esperamos, sino que hay injusticias claramente remediables en nuestro entorno que

quisiéramos suprimir"

(Amartya Sen)

Tratar a continuación acerca de la justicia obedece a que hasta ahora hemos mirado "el derecho en sí": sus orígenes o referentes materiales.

Estudiar la justicia, por su parte, es tratar del derecho ya no en su fuente sino en su fin -aunque con una ligazón total-, es decir, mirar su proyección, su función o utilidad final, el para qué último del derecho; es la manera actual de mirar a la justicia, esto es, como fin del derecho; ciertamente en la antigüedad, la justicia era el mismo derecho, $\mathrm{y}$ una de sus manifestaciones era la justicia distributiva, la que hoy se considera el fin del derecho en su sentido más general; podría decirse así en la antigüedad: la justicia (el derecho) es conmutativa (entre iguales), y/o distributiva (de superior a inferior); sin embargo hoy la concepción ha cambiado en buena medida a causa de la llamada cuestión social proveniente del siglo XIX y es por eso que se habla de la justicia social (la misma justicia distributiva) como fin del derecho, se volvió exógena a él, pero en tiempos remotos no era más que un tipo de derecho.

\section{A. ALGUNAS NOCIONES DE JUSTICIA}

Como dijo Hans Kelsen, la justicia es el eterno sueño de los hombres. Ello no quiere decir otra cosa, a nuestro parecer, que los hombres se han preocupado por ella siempre, que los grandes pensadores han dado su aporte porque les preocupa, y que la justicia es algo que necesita ser puesto en práctica de continuo, que no hay fórmulas "eternas" de ella, o mejor, sí puede haber fórmulas o definiciones perennes de justicia, pero que necesitan ser dadas, concretadas, hechas, en cada momento histórico, aquí y ahora. 
Ya Platón se interesó vivamente por ella y dijo que la justicia era que cada quien en la polis cumpliera su trabajo; hermosa concepción de la justicia: somos para la polis, para la ciudad, para la política. Y allí, en la polis, cada quien debe hacer su función bien hecha, de manera competente y apta; haciéndolo se es justo: el campesino, el guerrero, el gobernante..., en lo suyo, en lo que sabe hacer, si lo hace, es justo.

Aristóteles también se ocupó de ella y le dedicó un libro de su Ética a Nicómaco; dijo que la justicia era lo legal y lo igual; que dijese que era lo legal era algo apenas lógico dado que el griego antiguo vivía en función de la polis y dentro de ella la ley tenía un papel capital; los griegos valoraron en gran medida la ley; cumplir la ley era ser libre; la ley y el hombre eran como una misma cosa; lo repitió Francisco de Paula Santander en el siglo XIX en Colombia al decir: "Colombianos, las armas os han dado la independencia, las leyes os darán la libertad". Para los griegos la ley era sinónimo de libertad, no de esclavitud, como pareciera que se concibe hoy en día: ley=esclavitud; la concepción de la ley como sinónimo libertad, debe, a mi juicio, rescatarse pues la ley es un valor de la vida en comunidad; desde luego con las características siempre sabias que se han dicho que debe tener la ley: general, pocas leyes, hechas por verdaderos sabios, duraderas, fundamentales, como decía Rousseau (Sartori, 1994, p. 160); es una tarea difícil de realizar, que debe comenzarse por el recobrar el prestigio de los legisladores, y, también, por la reducción del arsenal legal que es hoy tan abundante.

Agrega Aristóteles: la justicia es lo igual: lo igual exacto a veces y lo igual proporcional en otras ocasiones, dado que la justicia entre los hombres, libres, espirituales, no se puede medir siempre exactamente, pues el hombre es enigma, misterio, y, por tanto todo lo suyo es apenas aproximación. Lo contrario de hoy cuando todo se mide con parámetros exactistas.

Ulpiano en Roma dijo la célebre y clásica definición de que la justicia es la constante y perpetúa voluntad de dar a cada cual lo suyo: suum quique tribuere. No es pensar simplemente lo que es del otro, no, es sobre todo darlo. ¿Qué se da? Pues lo suyo de cada quien, lo que hoy llamaríamos derechos humanos, o en términos más generales, los bienes propios de cada persona por serlo: la vida, la propiedad...

Esta definición fue muy apreciada y seguida también por Tomás de Aquino en la Edad Media (s. XIII).

Marx a su turno dijo que la justicia es dar a cada quien según su capacidad, a cada quien según su necesidad (Kelsen, 2005a, p. 53). 
Kelsen afirmó que la justicia es algo de competencia del derecho positivo, la regula la ley positiva en cada caso; otra cosa es ilusión, otra cosa es una justicia "vacía" (2005b, pp. 80 y ss.).

De la justicia se han vuelto a ocupar filósofos de la actualidad como Jhon Rawls (Una teoría de la justicia), situándola en las instituciones liberales que la dan como equidad; Amartya Sen (La idea de la justicia), viéndola de manera doble, es decir, dada tanto por las instituciones democráticas pero también realización de cada quien en su vida; Michael Sandel (Justicia), viéndola como un hacer lo que se debe..., etc.,

Así, podríamos hacer un recuento de la justicia por autores. Solamente hemos mencionado algunos para hacer ver su importancia para la humanidad y para el derecho.

Aparte las reflexiones concretas sobre esas pocas definiciones de justicia, con ello se ven ratificadas las palabras iniciales de Kelsen: la justicia es el eterno sueño de la humanidad; en realidad de verdad la justicia es así, un sueño, una tarea siempre permanente de los hombres puesto que ella es una "virtud práctica" que siempre necesita la concreción del dar; ya lo dice el Papa Benedicto XVI: "Así, pues, el Estado se encuentra inevitablemente de hecho ante la cuestión de cómo realizar la justicia aquí y ahora... Éste es un problema que concierne a la razón práctica" (Benedicto, 2005).

$$
* * *
$$

\section{B. LA JUSTICIA COMO FIN DEL DERECHO}

Fin del derecho es, se dice normal y generalmente, la justicia. Pero también se dice que fin de la justicia es el derecho. Respecto de esto último, es decir, que el derecho es fin de la justicia, es una lógica conclusión de analizar la justicia como dar a cada quien lo suyo: en efecto, si lo suyo es el derecho, darlo es el fin de la justicia. Es una especie de círculo eterno. Podría decirse que la justicia y el derecho se besan, iustitia et ius osculatae sunt, ambas se necesitan mutuamente, se buscan recíprocamente. Es más, iustitia deriva de ius por lo que ius es fundamento de justicia y, como el fundamento de algo es fin al mismo tiempo, resulta de ello entonces que la interrelación de ambos conceptos es total y evidente, se confunden; quizá por ello Arthur Kaufmann afirma que la iusfilosofía, ciencia que pretende llegar a la esencia del derecho, dice que ella es una "doctrina de la justicia" (2002, p. 39). 
Ahora bien, ¿puede decirse que la justicia es el fin único del derecho? ¿Puede haber otros fines del derecho? El Preámbulo de la Constitución Política de Colombia de 1991, por ejemplo, incluye varios fines del Pueblo de Colombia, en el siguiente orden informal: vida, convivencia, trabajo, justicia, igualdad, conocimiento, libertad, paz. La justicia aparece, como se ve, solo como uno de los fines del Pueblo colombiano, valga decir, de su derecho constitucional.

No obstante, tratemos de hacer una compilación de fines, un tanto forzosamente, diciendo que todos esos fines se incluyen en la justicia a fin de procurar una cierta unidad de tratamiento iusfilosófico. Esa inclusión puede obedecer también, no lo dudamos, al prestigio que actualmente tiene el valor de justicia, y, sobre todo, a las grandes obras filosóficas actualmente en boga: la de Rawls ("Una teoría de la justicia"), la de Sen ("La idea de la justicia"), la de Sandel ("Justicia, ¿hacemos lo que debemos?"), arriba mencionadas, entre muchas.

Y así, siguiendo ese sendero posible, autores como Mauricio Beuchot Puente dice expresamente que el fin del derecho es la justicia, autor que asocia a su posición, a Jürgen Habermas, para quien la legitimidad del Estado no se abastece solo con la legalidad, sino que además se requiere que las leyes sean "justas" (2006, p. 115).

Para abundar un poco más en la justicia propia del derecho, me parece pertinente traer a colación en este momento la postura de Benedicto XVI expuesta ante el Bundestag en septiembre de 2011.

La pregunta que se formulaba el Papa (y no se diga ahora que cómo traigo a colación en estas reflexiones a un Papa dado que la ciencia del derecho ya es autónoma e independiente de las religiones, laica y no confesional; pues bien, ante esa objeción respondo que la teoría de la complejidad, la tolerancia, y el diálogo de ideas me llevan a estudiar todo tipo de pensadores sin prejuicios), la pregunta de Benedicto XVI, empezaba a decir antes, es: ¿cómo saber lo que es justo?

Dice Benedicto XVI que la respuesta a lo que es justo se torna hoy muy difícil dada la idea positivista kelseniana de que la razón y la naturaleza se hallan separadas desde hace más de medio siglo; Benedicto XVI en su discurso al Bundestag invitaba a volver a la idea de lo justo que se tuvo siempre desde la filosofía griega, desde el derecho romano, y desde la Edad Media: los criterios de lo justo -decía el Papa- nos lo proporciona la conjunción de naturaleza y razón, y ambas unidas en un Spiritus Creator, 
tal como el Iluminismo jurídico, las declaraciones de derechos humanos del liberalismo y la Ley Fundamental alemana de 1949, lo intuyeron.

Decía además que el edificio jurídico actual desde Kelsen era como un edificio encerrado en sí mismo (¿proveniente del pienso luego soy cartesiano? Respondo: sin duda), pero que debía abrirse, apertura que empezaba a verse al menos de tejas para abajo en los movimientos ecologistas actuales.

Así pues, parece oportuno y adecuado tener este punto de referencia sobre la justicia en el derecho, o para el derecho, dado en estos tiempos por una voz acreditada universalmente.

En lo que sigue iremos viendo en los distintos conceptos que abordemos (libertad, igualdad, medio ambiente, etc.), lo que parece más justo, buscando después el punto medio.

C. HERRAMIENTAS GENERALES PARA ALCANZAR, PARCIALMENTE, LA JUSTICIA

¿Cómo se consigue la justicia? ¿Cuáles son las "herramientas” para conseguir la justicia, cuáles son los materiales de ella como dice Sen (Sen, 2010a, pp. 253 y ss.)?

Desde luego lo que aquí se diga no pasa de ser la exposición de algunas herramientas que ayudan a conseguir la justicia, al menos en alguna medida; la justicia perfecta en la tierra no es dable; es una tarea siempre permanente y constante.

Ulpiano dice que la justicia se consigue dando: es dar a cada quien lo suyo; pensamos que la acción de dar (no las meras intenciones, que, desde luego son necesarias también, y precedentes al dar propiamente tal) se puede conseguir de distintas maneras:

a. Ese cumplir con la naturaleza personal que asigna suyas cosas a cada persona, así como cumplir con lo justo pactado, se consigue mediante un "imperativo (por utilizar esa expresión de Kant) ético" proveniente del mismo derecho; la ética del derecho lleva, de alguna manera, facilita a cumplirlo porque se lo ve razonable éticamente; esa ética ínsita del derecho facilita el darlo; dice Amartya Sen en este mismo sentido que los derechos humanos "son realmente vigorosos pronunciamientos 
éticos sobre lo que se debe hacer" (2010b, pp. 389-390); de esta manera el primerísimo instrumento para dar lo justo es, a nuestro juicio, la ética que está contenida en el derecho mismo; es también de algún modo lo que el mismo Sen llama los comportamientos reales de las personas en búsqueda de lo justo.

b. Pero puede cumplirse no sólo porque la ética del derecho en sí mismo considerado impulse a ello, sino también por el temor a ser castigado con una sanción impuesta por el derecho; así, el segundo instrumento para dar lo justo es la coerción (compuesta de la amenaza y de la pena anunciadas exteriormente), típico instrumento -exterior- creado también por el derecho que, desde luego tiene muchas variables en manos de la política legislativa; en efecto, las penas tienen un inmenso espectro: van desde la cárcel, con pocos o muchos años, hasta llegar a lo que hoy se llama "justicia transicional", creada para situaciones de búsqueda de la paz en países con serios conflictos civiles de guerra, que puede no implicar cárcel aunque sí otro tipo de sanción como la reparación material de las víctimas y/o la reconstrucción de la memoria histórica.

c. Ese dar también se puede conseguir desde la política, o/y, desde la economía; la política y la economía, son otros brazos, además de los mencionados de la ética en el derecho y de la sanción jurídica, para alcanzar la justicia general.

Ya Aristóteles vislumbró que la justicia se podía conseguir mediante la política: a continuación de su libro de ética, Ética a Nicómaco (donde está incluida la justicia o el derecho), vino el libro de la política.

La economía, por su parte, vino más tarde, aunque por ejemplo Aristóteles la trató levemente al tratar de la esclavitud como mano de obra de los recursos materiales del día a día (=economía), también Tomás de Aquino y sobre todo la Escolástica española al tratar de la necesidad de la austeridad en el uso de los bienes materiales (=económicos), así como Calvino con la necesidad de incrementar la propiedad como signo de predestinación divina.

La economía como ciencia aflora sólo con el mercantilismo de la Modernidad, seguido del fisiocratismo, y tratada ya más científicamente por Adam Smith en el siglo XIX como la ciencia de la oferta y la demanda de bienes en el mercado, fruto del interés propio como motor de la economía.

Lo anterior es porque realmente la justicia es algo muy grande, omnicomprensivo y complejo; por eso contribuye a conseguirla en realidad 
de verdad no sólo la ética en el derecho, y/o el temor a la sanción jurídica exterior, sino también por muchas instancias más como las mencionadas de política y economía; en síntesis, esas instancias serían:

- El derecho en sí mismo considerado mediante el imperativo ético que él mismo conlleva y la obligatoriedad de la sanción jurídica externa: amenaza y pena.

- La política mediante un Estado bien constituido con todas sus instituciones (Locke) en pro de lo justo; creemos que el modelo más justo es la democracia (volveremos sobre ello); y dentro de ella, más específicamente, la política legislativa (concerniente con la Teoría del Estado y la Teoría del derecho), así como una política judicial (atinente a la administración judicial propiamente tal);

- La economía como arte de administrar los bienes materiales.

De esta manera, recurriendo a un conjunto de factores en pro de la justicia, creemos dar una visión filosófica de la misma, es decir, "multifactorial", lo más universal posible, y no reduccionista o fragmentada, y sabiendo que entre ellas existe una inter-relación necesaria: ninguna se autoabastece, sino que necesita de las otras.

Dicho de otro modo: desde siempre en teoría política, pero especialmente desde el siglo XIX bajo el concepto de "Estado de derecho", la conexión entre derecho y política se ha hecho innegable; y Joseph Stiglitz, además, vincula política con economía cuando afirma expresamente: "Hemos visto que la política y la economía son inseparables" (Stiglitz, 2012, p. 355), por donde podemos deducir que el derecho, la política y la economía son inseparables todas ellas tres, y los tres son básicos, entonces, para la obtención, en alguna buena medida, de la justicia.

$$
* * *
$$

D.

\section{LA HERRAMIENTA CONCRETA DE LOS DERECHOS HUMANOS}

"El nuevo imperativo categórico de nuestro tiempo es este: que Auschwitz no se repita"

(Francesco D’Agostino).

Veamos ahora más en concreto la herramienta para alcanzar la justicia de dar los derechos de la persona humana: se dijo antes que es justo dar los 
bienes, los derechos, dar a cada quien lo suyo. Concretemos esto un poco más a fin de visualizarlo teórica e integralmente. Para ello es conveniente dar una visión iusfilosófica (o integral) de los derechos humanos.

Los derechos humanos son un tema de especial intensidad en la iusfilosofía hoy, aunque tiene que ver mucho también con la historia de las ideas políticas y del constitucionalismo; esto es muy esclarecedor para entender que la iusfilosofía toca este tema de los derechos humanos sólo en cierta medida.

Los derechos humanos son la expresión en el derecho de la dignidad de la persona humana. La dignidad humana es el piso de los derechos humanos, su razón de ser, su fundamento. Pero... ¿qué es esa dignidad?

La dignidad es toda la contextura del hombre: su cuerpo y su espíritu juntos, únicos, no repetibles, marcados por la razón, la inteligencia, el genio, la creatividad, la voluntad, el esfuerzo por conseguir sus aspiraciones, su espiritualidad, en fin, todo un conjunto de capacidades que ningún otro ser posee y que son claramente distingibles de los demás seres; podría decirse que es algo tan evidente que no tendría en realidad qué aclararse nada acerca de la dignidad del ser humano.

El valor de la persona humana empieza a verse en la antigua Grecia con Protágoras (s. V a. de C., con su célebre afirmación: "El hombre es la medida de todas las cosas"), luego con Sócrates (s. V-IV a. de C., con el "Conócete a ti mismo"), y después con Aristóteles (s. IV a. de C.), con su ética de la virtud personal. Son como sus principales hitos en Grecia.

Pero el descubrimiento del valor de la persona humana llega a un punto no alcanzado hasta entonces con el cristianismo: la persona es individuo, no masa ni multitud, como pensaban los antiguos griegos; la persona es libre, no objeto de la fatalidad del destino como también pensaban los antiguos griegos; la persona es imagen de Dios; la persona es capaz de cambio (Mounier, 2001).

Con el absolutismo político de los siglos XVI y XVII, la persona queda "opacada" en aras del Estado nacional naciente; los derechos de la persona son pocos en el absolutismo político: para Hobbes, por ejemplo, el único derecho natural es el derecho a la conservación de la vida; dice literalmente: "El derecho natural, que los escritores llaman comúnmente jus naturale, es la libertad que cada hombre tiene de usar su propio poder, como él quiera, para la preservación de su propia naturaleza, es decir, de su propia vida..." (Hobbes, 2007, p. 132). 
Con el liberalismo político, Locke habla de los derechos naturales a la vida, a las posesiones y a la libertad; más derechos que los que enunciaba y reconocía Hobbes (Locke, 2007, p. 124).

Paulatinamente los derechos de la persona llegan a su apogeo con las Declaraciones de derechos humanos: Bill of rights, Declaración de los derechos del hombre y del ciudadano..., en los siglos XVII y XVIII.

Dichas Declaraciones son arengas que manifiestan juridicidad de los derechos humanos, vinculantes, obligatorias para el Estado y los individuos en la sociedad; desde luego las concreciones de esos derechos se tienen que dar en última instancia en sede judicial aunque lo deseable es que se concreten en el día a día de la vida social; las sentencias de los jueces especifican, aclaran, hacen casuística de los derechos humanos enunciados en dichas Declaraciones; las Declaraciones son mucho, pero al mismo tiempo son poco, pues han de encarnarse en la cotidianidad y en las sentencias para cada caso, por parte de la autoridad del Estado.

El Estado debe ser el garante del reclamo de los derechos; el Estado ya no es el Leviatán total sino quien debe velar, garantizar, los derechos de la persona humana individual. El Estado liberal y constitucional sufre, de esta manera, una inversión respecto al viejo absolutismo; La razón de ser del Estado es ahora velar por los derechos de la persona humana y no ser sacrificados en el Estado, por el Estado, para el Estado. Esa es la razón de ser del Estado hoy en día después del absolutismo y desde luego después del totalitarismo, esto es, custodiar a la persona y a todo lo que ella comprende y significa en sus derechos fundamentales.

Los derechos humanos empezaron con el liberalismo político su carrera; llevamos entonces más de tres siglos de derechos humanos, llegando a ese momento culmen que fue la "Declaración Universal de los derechos del hombre", del 12 de diciembre de 1948, por la ONU.

Desde luego los derechos humanos sufrieron un "apagón" severo con los totalitarismos de Estado del siglo XX (comunismo soviético, fascismo, nacionalsocialismo); pero renacen después de la caída de los totalitarismos con una fuerza arrolladora, hasta hoy en día; puede afirmarse que los derechos humanos son el tema de nuestro tiempo.

Cuando se habla de derechos, implícitamente se encuentran junto a ellos los deberes; los derechos son "frente" al Estado; los deberes son, ante todo, de los "ciudadanos" para con esos derechos; pero deben extenderse también 
al Estado; en la Constitución Política de Colombia de 1991 aparecen esas obligaciones expresamente en los artículos 2, 5, 7 y 8 .

Hagamos una observación y una crítica: en esa carrera de los derechos humanos existe una "prevalencia" de lo individual frente a lo colectivo; se ha sido excesivamente individualista, con sacrificio de lo colectivo, y eso muchas veces con la aquiesencia de las Altas Cortes, pero ante todo con la licencia de la sociedad misma que aparece como insensible a los derechos humanos; una muestra de ello es que existe el derecho a elegir, por ejemplo, pero al elegido no se le exigen muchas cualidades (con sacrificio de lo colectivo por parte de la normativa jurídica); la libertad de conciencia está amparada, pero en virtud de ella cualquiera puede expresar sus convicciones o creencias sin mayor respeto por el otro; la libertad de expresión e información no se controla por el Estado ni se autocontrola por los medios de comunicación; la paz social como derecho sigue siendo una utopía pues grupos al margen de la ley tienen a las armas como el único camino para las reivindicaciones políticas y sociales; otra muestra es que existe el derecho a la vida pero cada vez se le abren más las puertas al aborto libre.

Y en línea con lo anterior, ciertamente en la generación de los derechos, primero fueron los derechos civiles y políticos de tinte individualista; luego los derechos sociales, económicos y culturales; y por último los derechos colectivos y del ambiente; pero los primeros, los individuales, han sido sobrevalorados; no así los colectivos y del ambiente que, aunque posteriores en el tiempo, siguen apareciendo muy rezagados.

Debería haber más equilibrio a este respecto en la "familia de los derechos"; deberían valorarse más los sociales, económicos y culturales y, de manera muy especial, los colectivos y del ambiente; los derechos humanos deben mirarse filosóficamente, esto es, integralmente: todos los derechos en conjunto, en familia, sin soluciones de continuidad, y valorando derechos y deberes también conjuntamente; ese es un aporte de la iusfilosofía a los derechos humanos; pero así también como se habla de prevalencia de los derechos de los niños, debería reconocerse la prevalencia de los derechos de los pobres y la prevalencia de los derechos colectivos y medioambientales; mirar los derechos integralmente no significa no poder establecer jerarquías entre ellos [en Colombia lo ambiental está francamente sacrificado en aras del dinero, de las ganancias; a ese respecto podría verse la denuncia de Juan Gossaín sobre la minería de Níquel en el Departamento de Córdoba, (2013, marzo 7)].

Por eso en los sistemas tan individualistas como el colombiano, lo social, colectivo y del ambiente, está haciendo su presencia mediante protestas, 
paros, y mítines; la desobediencia civil y la huelga están a la orden del día (iusfilósofos como Oscar Mejía Quintana, precisamente, han hecho entre sus pilares de su iusfilosofía, la desobediencia civil); en esa carrera se ve, entre otras cosas, la diferencia entre el "neoliberalismo" (que sobre-aprecia lo individual) y el "socialismo" (que pretende apreciar más lo social, económico, cultural, colectivo y del ambiente); no debe dejar de resaltarse, pues, que en los derechos al medio ambiente se juega el futuro del hombre (a este respecto recomendamos vivamente la lectura de La opción tierra, de Leonardo Boff, sobre la que volveremos más adelante).

Veamos todo lo anterior bajo la óptica de la tríada liberal de libertad, igualdad y fraternidad:

D.1. LA LIBERTAD

"La libertad de los hombres en un régimen de gobierno es la de poseer una norma pública para vivir de acuerdo con ella; una norma común establecida por el poder legislativo que ha sido erigido dentro de una sociedad; una libertad para seguir los dictados de mi propia voluntad en todas esas cosas que no han sido prescritas por dicha norma; un no estar sujetos a la inconstante, incierta, desconocida y arbitraria voluntad de otro hombre, del mismo modo que la libertad natural consiste en no tener más trabas que las impuestas por la ley de naturaleza" (John Locke).

"Lo anterior no significa que se reconozca la objeción de conciencia frente a cualquier norma legal, sino que se trata de excepciones a la obligatoriedad al cumplimento de la ley"

(Pablo Gutiérrez).

Dentro de los derechos fundamentales del hombre de primera generación, propios de las revoluciones liberales, su "matriz" es la libertad.

Hay que reconocer que el tema de la libertad se desarrolló a partir de la revolución francesa de fines del siglo XVIII (1789) con sus lemas de "libertad, igualdad, fraternidad", aunque ya estaba incoada en la revolución gloriosa de Inglaterra (1688) y en la revolución liberal estadounidense (1776). 
Antes de ella-de la libertad-, otros ideales preocupaban a los espíritus; en la Antigüedad y el Medioevo los temas fueron más bien la verdad, el orden, la sabiduría y la naturaleza. Con Hobbes en los comienzos de la Modernidad racionalista la preocupación fue la paz como objetivo prioritario, dado que para él "el hombre es lobo para el hombre" (Homo homini lupus; frase que se remonta a Plauto en el s. III a. de C. y que luego se utilizó abundantemente), situación de guerra de la que hay que salir con una razón que busque la paz mediante el contrato social.

Con la Revolución Francesa, contando desde luego con los antecedentes mencionados (revolución inglesa y revolución norteamericana), así como los antecedentes del subjetivismo jurídico de Guillermo de Ockham en el s. XIV (es decir, el derecho como facultad, no tanto como orden o lo justo en sí mismo del que hablaba el siglo XIII), y el antecedente liberal religioso de Martín Lutero en el siglo XVI con la libre interpretación de la Escritura Sagrada, se desarrolla, como nunca antes en un éxtasis de los espíritus, la preocupación en todos los terrenos de la libertad especialmente de la libertad "política y jurídica".

Ésta -la libertad-se oscureció después con los "totalitarismos de Estado" del siglo XX por causa de esa ideología política asfixiante de la libertad humana, pero renace por mera reacción natural con una fuerza especial, después de la caída del totalitarismo del Estado a fines del siglo XX: ahí estamos, ahí nos encontramos, y ahí permaneceremos quizá por un tiempo.

¿Surgirán otras aspiraciones en el hombre? No hay duda pues la historia no es igual siempre; se avizora desde ahora la preocupación, por ejemplo, por lo natural físico, por lo medioambiental; y si la libertad humana-sobre todo en su versión del "libertarismo" (Sandel, donde se ha llegado en nombre de la libertad a algún caso de canibalismo)- se "extrapola", como sucede ya en tantos aspectos, entonces es previsible su revisión más temprano que tarde; por eso hay que procurar que ella se mueva en la línea del punto medio a fin de que no se oscurezca del horizonte humano a causa de sus extremos en este caso por exceso.

Pero... ¿qué es la libertad humana? Podríamos recordar para intuirla lo que san Agustín en su libro Las Confesiones dijo acerca del tiempo: si me preguntan qué es el tiempo no lo sé, pero si no me preguntan lo sé; algo así puede decirse de la libertad, es difícil dar un concepto de ella, como en general de todos los grandes valores con que se topa el hombre: Dios, la vida, el amor... Empero podemos aproximarnos a ella. 
Libertad es sinónimo de posibilidad del hombre. Si quiero correr y no puedo por carecer de piernas, no soy libre físicamente, no hay posibilidad de correr; pero el correr, si puedo hacerlo físicamente, está antecedido de "querer" correr, luego la libertad supone primero un deseo interior; el deseo es presupuesto de la libertad [es lo que Sartori llama "libertad interior"; (Sartori, 1994a, p. 153). Apetecer, querer, desear es, pues, plataforma de la libertad como posibilidad.

Pero podríamos preguntarnos también: ¿y cómo desear algo antes de su posibilidad real? Pues bien, realmente se está previamente capacitado para ello, la estructura natural de la persona lo permite: se desea correr, se desea comer...; se está llenos de deseos; el deseo es connatural al hombre, no tiene mayor problema al menos en su raíz natural.

Pero... ¿todo deseo, toda voluntad, toda apetencia es buena, conviene, representa un bien para el hombre?; se puede desear robar, pero ese deseo no es bueno, no representa realmente un "bien integral" para el hombre y para los demás hombres. Entonces parece que el deseo no basta, es necesaria una previa condición ética dada por la inteligencia.

Posibilidad, deseo, inteligencia se inter-relacionan; son una secuencia necesaria y lógica; son un trípode del hombre en su éthos; es decir, la libertad tiene un co-relato ético; la posibilidad, que es la libertad, tiene una connotación ética; hay una libertad, primitiva, salvaje, elemental, que podría no tener ética: sería el puro desear sin más, el puro elegir sin más, pero, puesta la inteligencia y la reflexión de por medio, existe una libertad ética, culta, civilizada.

Pero todo lo dicho hasta aquí es la que podríamos llamar con palabras prestadas, la libertad filosófica, interior, metafísica, personal, de autorealización (1994b, p. 153).

En el mundo de la libertad hay otra que se ha llamado la libertad exterior, que se encuentra más allá del puro deseo, y que se vincula con la posibilidad real de hacer, que es empírica; por ejemplo, “dejar hacer, dejar pasar”, libertad de empresa y libertad de comercio: ella -la libertad exterior en todas sus manifestaciones-completa a la libertad interior; ambas son complementarias, se necesitan mutuamente.

A esta segunda clase de libertad -la libertad exterior-, se han referido algunos diciendo que es la libertad propiamente "política", y que sería la verdadera libertad liberal, la real libertad, la solución liberal de la libertad dentro de la polis, y es la que tiene que ver también con el derecho más propiamente (p. 153). 
Sería la libertad de no ser estorbado por el otro o por el poder político; pero como se ve, es una libertad nacida del "temor" al otro (es lo que sostiene Hobbes, quien decía que "el hombre es lobo para el hombre", concepción pesimista del hombre), o nacida para crear el Estado absoluto y por tanto libre de injerencias exteriores como el poder religioso (también lo dice Hobbes), o para evitar los excesos del Estado absoluto hobessiano (como lo sostiene Locke); son libertades, pues, "negativas", pesimistas en su principio.: temor al otro hombre (Hobbes), o temor al Estado (Locke).

A nuestro juicio la libertad debe ser, por el contrario a los filósofos mencionados (Hobbes \& Locke), una libertad en "positivo", una libertad para hacer al hombre más hombre integralmente, es decir, para desarrollarse en lo que son todos sus bienes (no sus males, retrocesos, o vicios), y para construir comunidad política.

Pero preguntémonos ahora: ¿Puede contentarse el derecho con descubrir y lanzar al mundo de los códigos y las leyes (pitchear) la libertad exterior, la libertad "de" tal o cual cosa (vgr. la libertad de pensamiento, de expresión de información, de conciencia...)? Parece a primera vista que sí, que esa sería la tarea del derecho, tal como lo sostiene por ejemplo Giovanni Sartori, inspirado en filósofos políticos como Hobbes, Locke, y Rousseau; no se trata entonces de la libertad "para", que sería la libertad puramente filosófica, la de la auto-realización (1994b, pp. 154 y ss.). Es la solución liberal a la libertad, recordábamos antes con Sartori.

Pero la verdad, a nuestro parecer, es que el derecho después de la mera ley que reconoce libertades "de", pasa a ser derecho "cátcher", con contenido, tal como lo expresan las sentencias de los jueces en su parte motiva y argumentativa: después de haber lanzado y reconocido la libertad "de", el derecho pasa, con la colaboración de la sociedad, del debate social, con la colaboración de saberes como la sociología, la moral, la economía, y desde luego con el aporte de los jueces, a llenar materialmente de contenido ese derecho inicial pitcher, en un equilibrio que debe ser armónico de la ley exterior, formal, con su contenido material.

En esta línea hoy se ha llegado a hablar de las "capacidades" de la persona humana, como "otro insumo" básico de la justicia. ¿Qué es entonces la capacidad? La "capacidad" del individuo no sería una capacidad concreta desde el "placer" o la "felicidad", al estilo benthamiano, sino una capacidad "multifactorial"; no sería la mera libertad "de" sino la libertad "con contenido"; dice Amartya Sen a este respecto: "El concepto de capacidad se vincula así muy estrechamente al aspecto de oportunidades de la libertad... La capacidad 
que nos concierne aquí es nuestra habilidad de lograr varias combinaciones de actividades..." (Sen, 2010, pp. 261, 265). Esto entronca perfectamente con lo dicho atrás de que la libertad pitcher debe entrelazarse con la libertad cátcher; que la libertad exterior debe conectarse con la libertad interior, la política con la filosófica, la formal con la libertad con contenido.

Con otro lenguaje, podríamos decir que se trata también del tema de "cuáles" libertades se reconocen, y además, "cuánto" (límites) de libertad debe haber.

Hablar de "cuáles" libertades, pertenece al mundo de "libertades de"; y "cuánto" de libertad, se refiere "hasta dónde" debe llegar la libertad, es tema que pertenece al mundo de la "libertad para"; es tanto como decir también que derecho y política se necesitan mutuamente; la libertad "de", tan propia del derecho formal positivo, está condicionada por el "modelo político", que establece según su manera de concebir el mundo, el quantum de libertad: liberal democrático, estatista, etc..

Este tema, por lo tanto, es un tema muy amplio, que no sólo concierne a la filosofía en general, sino también a la filosofía y teoría política, donde tienen que tratarse los problemas sociales con criterios políticos (vgr.: el cuánto de libertad depende del momento histórico social, y así, existe el derecho de "consumir dosis mínima de droga", dado un problema de salud pública; también vgr., el cuánto de libertad depende del riesgo que se asume con una política de "paz", y así la paz presupone el derecho de no tener cárcel, aunque se puede sustituir por otra pena jurídica; etc.).

Aquí, en este tema por cierto, se encuentra dividida la humanidad, o un país concreto en su interior, que prefieren ahora o en otro momento, un tipo de Estado que limite o amplíe la libertad, y que postreramente repercute en el reconocimiento de libertades de tal o cual cosa. En esto por supuesto, cabe aplicar el postulado o criterio de los "resultados": por los frutos se puede medir el cuánto de libertad que, a su vez, repercute en reconocer después tal o cuál libertad "de".

De esa manera, como el hombre es unidad-corporo-espiritual, las dos libertades, la exterior y la interior, la legal y la filosófica, la jurídica y la personal, la estrictamente formal jurídica y la política, se encuentran imbricadas en alguna medida que habrá qué discernir en cada momento; separarlas del todo es convertir al hombre en un ser dual, dividido, esquizofrénico, de dos mundos separados, cosa que no le conviene al hombre, pues la esquizofrenia es una enfermedad mental; el derecho exterior, entonces, 
y el derecho con contenido, lo exterior e interior humanos, la política y la persona, deben retro-alimentarse.

La pura "razón pública liberal", autonomista, libertaria, la de la libertad "de" (aunque ciertamente es de más fácil aplicabilidad en el terreno político), resulta al parecer escasa; ella debe necesitar del "comunitarismo", que enfatiza lo moral y jurídico "con contenido"; derecho y moral se ayudan recíprocamente, ley y pretensión de corrección se ayudan mutuamente, so pena de caer en excesos como el caso del caníbal que recoge Michael Sandel en su obra "Justicia", al que ya hicimos referencia (Sandel, 2011, pp. 88, 89).

No basta, entonces, a nuestro parecer, la pura autonomía liberal pues ésta podría llegar a expresar excesos como el derecho a matar libremente con razones más o menos elegantes en nombre del derecho a la libertad.

He ahí la necesidad de que junto al derecho pitcher haya un derecho cátcher, que junto a la ley positiva formal, haya un derecho con contenido material moral; es toda una tarea a lograr bajo el postulado del punto medio, misión ardua, difícil, pero creemos que posible con la argumentación pública como supone la democracia verdaderamente tal, sin prejuicios de ningún tipo, ni religiosos, ni políticos, ni económicos, ni personales (Sen, 2010a, p. 351 y ss).

Dicho lo anterior podemos interrogarnos: ¿Pierde así el derecho su justa autonomía al tener que vérselas con la moral,con la política? La verdad es que sus perfiles, los del derecho, siempre deben ser colaterales, más o menos borrosos, necesitados de otros saberes, a contrario sensu de la teoría pura del derecho de Kelsen quien deseaba (el primer Kelsen, valga la aclaración) un derecho sin elementos extraños, así el iuspositivismo a ultranza se esfuerce por separar el derecho de la moral (en la orilla contraria del iusnaturalismo que siempre ha querido apoyar la ley en lo justo, en el iustum, en la moral).

Pienso que la cercanía entre derecho y moral es mayor de lo que se cree; el derecho es una moral (aunque ésta, sin sanción exterior, sensible, de autoridad externa), pero moral al fin y al cabo en muchos aspectos; además, el derecho no se puede reducir a pura técnica, a puro proceso vacío de contenido; desde luego la técnica jurídica es propia del derecho, pero éste siempre contiene un algo de moral, aun el mismo proceso; por eso, esa misma técnica jurídica debe llegar a aceptarse íntimamente por razones de conciencia, por cuanto el hombre es una unidad exterior e interior, y esto lleva de contera una vez más a pensar en la tarea de la iusfilosofía, que es llegar a la esencia del derecho. El derecho es entonces una moral cualificada o juridificada; no me parece acertado eso de decir que el derecho es extrínseco y la moral intrínseca pues ambas esferas son intrínsecas y extrínsecas a la vez, y ambas se necesitan recíprocamente. 
Agreguemos para terminar este acápite otro punto a título de una "aclaración”; ¿Cómo es posible que la libertad sea el centro de los derechos de primera generación, cuando entre esos derechos aparece el "derecho a la vida", por ejemplo, que no tiene qué ver "directamente" con la libertad?

La respuesta que daríamos es que se trata de "englobar" dentro de la idea de derechos, como una "técnica constitucional", fines, principios y derechos (pues por cierto el derecho a la vida aparece en el marco de la Constitución como las tres cosas, es decir, como "fin", como "principio" y como "derecho"), donde, junto a las libertades "de", aparece el derecho a la vida, que no pertenece directamente a la libertad; allí se mezclan entre otros derechos el mencionado de la vida con las libertades; así pues, ello es una mera técnica constitucional, la de englobar derechos, pero ello no quita la "centralidad" dentro de los derechos de primera generación del derecho de libertad [el cual derecho a la vida, además, se ha ido valorando exponencialmente como otro "insumo" de la justicia; así, Amartya Sen, cuando habla a favor de la vida en sí y de su calidad; dice Sen: "No resulta difícil apreciar la centralidad de las vidas humanas en las razonadas evaluaciones del mundo en que vivimos" (2010b, p. 255)].

D.2. LA IGUALDAD

"Aunque ya hemos visto atrás que 'todos los hombres son iguales por naturaleza', no quiero que se me entienda que estoy refiriéndome a toda clase de igualdad. La edad o la virtud pueden dar a los hombres justa precedencia; la excelencia de facultades y de méritos puede situar a otros por encima del nivel común; el nacimiento puede obligar a algunos, $y$ los compromisos y el beneficio recibido puede obligar a otros a respetar a aquellos a quienes la naturaleza o la gratitud o cualquier otro signo de respetabilidad hace que se le deba sumisión"

(John Locke).

Sólo la filosofía posterior a su primera hora (la de la primera hora no la alcanzó a entender pues decía que el fuerte es más que el débil, dejándose llevar por una visión meramente elemental y naturalista), y la religión cristiana (al predicar que los niños valen, que la mujer vale, que el pecador "vale", en contra de las desigualdades en que estaban antes de Jesús de Nazaret), enseñaron la igualdad en la antigüedad. 
La naturaleza física y la historia, mostraron hasta entonces, por el contrario, la desigualdad.

La igualdad reaparece después del Medioevo jerarquicista. Así como la libertad, tampoco la igualdad preocupó a los hombres en el Medioevo (Sandel, p. 179).

Fue el Liberalismo el que lanzó la preocupación por la igualdad diciendo que "todos los hombres nacen libres e iguales" (postulado que sigue apareciendo en la Constitución Política de Colombia en el art. 13).

La igualdad fue una consecución más tardía que la libertad dentro del ideario liberal; a ella, a la igualdad liberal, contribuyeron en gran medida el socialismo, la social democracia, el intervencionismo del Estado -en cuanto que la llevaron al plano real-, y, como dice Amartya Sen, se debió también a la Declaración Universal de los derechos humanos de la ONU de 1948, al reconocer y consagrar los derechos económicos, sociales y culturales (Sen, 2010, p. 412).

Así entonces, la igualdad es en buena medida "histórica", no es una aspiración que haya existido siempre; en la antigüedad y el Medioevo, la esclavitud y la servidumbre, respectivamente, fueron naturales y sin embargo sabemos hoy que no contribuyeron a la igualdad. La igualdad fue posterior, fue un grito liberal inglés (1688), estadounidense (1776), y francés (1789), originariamente, frente a la estratificación social medieval.

Frente a este tema de la igualdad ha habido fundamentalmente dos posiciones: la igualdad "civil y política" (unida a las libertades como acabamos de decir), y la igualdad "económica".

Con la primera se dijo que todos los hombres nacemos libres e iguales; pero nada es más retórico que esa afirmación, eso no es real: ni la libertad se consigue al nacer pues sólo es una conquista -como dice Hans Kung-, ni nacemos iguales (hay mucha diferencia de cuna, de cualidades naturales, etc.).

La segunda, la igualdad económica, fue más luchada y encarnada por los socialismos marxistas (aunque con un fracaso posterior notorio por caer en el igualitarismo): si somos iguales conseguimos la libertad; no es al revés, dice tal socialismo; más exactamente afirma que si tenemos los bienes materiales, obtenemos de contera la libertad (el problema muchas veces es que se consiguió lo material dentro del socialismo marxista pero después se le tuvo miedo a la libertad y se la fue aceptando a regañadientes: para la muestra un botón: aún hay presos políticos en Cuba); es lo dicho también 
dentro del campo liberal por John Rawls al hablar de la necesidad de los bienes primarios para alcanzar la libertad (aunque Rawls hace una defensa a ultranza de la libertad), posición que comparte hoy en día Amartya Sen parcialmente pues dice que la riqueza material es sólo un "medio" nunca un "fin" del hombre.

La historia más reciente muestra los extremos en esta materia: liberalismo y marxismo son opuestos radicalmente. El Liberalismo, al menos el de la primera hora, privilegia la libertad mientras que el marxismo idealiza la igualdad. Lo adecuado, lo que venimos tratando de sostener en estas reflexiones, es que las dos aspiraciones, la libertad y la igualdad, la igualdad la política y la igualdad económica, se "complementen" en un punto medio de equilibrio.

El filósofo norteamericano John Rawls ha hecho una contribución valiosa al tema de la igualdad con su creación imaginaria del "velo de la ignorancia", que se crea para favorecer una igualdad plena y desde el cual se imaginan dos principios fundamentales del "contrato social": el de las libertades básicas y el de la igualdad social y económica; ella sin duda ayuda a dicho equilibrio del punto medio.

La igualdad política se ha ido abriendo paso en Occidente desde hace un buen tiempo con la llamada "igualdad de oportunidades" ante todo en la educación (y sobre la que hay que volver nuevamente hoy, como pone de presente Joseph Stiglitz, p. 331). Ella igualmente contribuye e la consecución de esa igualdad con punto medio.

Como se ve, van apareciendo varios tipos de igualdad: la política (todos los hombres nacemos iguales), la económica (iguales derechos económicos), la de los contratos reales (igualdad conmutativa), la de rentas y patrimonio (igualdad distributiva). A las anteriores podrían agregarse otras más concretas como las de autonomía mutua en los contratos, la de reciprocidad en los contratos, la de conocimiento (en los contratos, por la cual, aunque alguien pueda adherirse a otro, ese otro cuenta con el conocimiento de una labor específica; por ejemplo en el área de seguros), (Sandel, 2011, pp. 161 y ss.), la de oportunidades (Sartori, 1994, pp. 178 y ss.), etc. ¿Todas ellas no ayudan de algún modo al equilibrio del punto medio en materia de igualdad? Se cree que sí.

Digamos entonces que no parece que la igualdad deba ser "aritmética", "igualitarista", sino la "proporcionada", la "aproximada", la "geométrica", la "armónica", la "equitativa", la de Aristóteles -el viejo ARISTóteles 
siempre tan vigente en tantas cosas-, aunque desde luego debe ser una igualdad regulada por el Estado, como dejan ver las nuevas tendencias socioeconómicas exitosas de países como Brasil, por mencionar uno de nuestra área, con fructuosos resultados positivos en economía general y social.

Se admite hoy que no es posible una igualdad "absoluta", imposible e indeseable por lo demás, sino una igualdad "relativa", "realista", "regulada", se repite, por el Estado.

En el otro extremo a la igualdad aproximada está la desigualdad total, el desenfreno de suertes económicas, la falta de controles estatales, es decir, las posiciones libertarias tipo Hayek, Noczik, Reagan, Tatcher, Friedman, para quienes lo importante es la libertad -y lo demás pasa a segundo plano-, incluida la igualdad (Sandel, 2011, pp. 71 y ss., pp. 161 y ss.); no compartimos dichas posturas por extremas; no compartimos esa desigualdad, pues no es justo que exista un 25\% de la humanidad excluido (Zabala, Iriarte, 1991), ni menos todavía, un 99\% por ciento excluido (Stiglitz, 2012a). Con ello se ve que la desigualdad, desgraciadamente, se ha ido incrementando en el mundo, y, con ello, el aumento de la criminalidad, el alejamiento de la ley, y la pérdida de la democracia (2012b); ante lo inmediatamente anterior podemos interrogarnos: ¿es que ha fracasado la igualdad de oportunidades que brinda la educación? ¿Es que ha fracasado el sistema educativo o el tipo de educación? ¿Es que ha fracasado la regulación estatal de los medios de producción o del capitalismo? Sí, en buena medida. Entonces, ¿es que acaso la igualdad es un objetivo quimérico, e inevitable la desigualdad entre los humanos? ¿Hay correctivos a la desigualdad?

Lo anterior lo que muestra es que la igualdad es un "ideal" que requiere de un "punto de equilibrio", de un punto medio entre igualitarismo absoluto y desigualdad sin controles; se requiere de una sumatoria de igualdades todas, o casi todas, deseables, así como de una "lucha incesante", aquí y ahora-por ser una esfera de la "razón práctica" como ya se dijo de la justicia-, pues lo que trata de imponerse entre los seres humanos es la desigualdad (y es que si nos miramos el propio cuerpo hasta nuestras propias manos y pies, hasta ellos, son desiguales en nosotros mismos, aunque también es cierto que otros órganos pares puedan ser simétricos); la igualdad absoluta no existe, y hasta hay normas jurídicas que son desiguales, pues la norma de normas es la Constitución, o los derechos de los niños prevalecen; pero entonces... ¿por qué luchamos por la igualdad? Pues porque hay "sectores" posibles de igualdad.

Desde luego la igualdad total, que es un mero signo aritmético $(=)$, no es de humanos; lo humano en realidad de verdad es la armonía en la desigualdad 
(recuerdo cómo hace algunos años me llamaban la atención los barrios en E.U, donde todas las casas son desiguales - al contrario de nuestras urbanizaciones masificadoras e idénticas- pero, en medio de esa desigualdad, veía una gran armonía estética); la "equidad" (como la vio Aristóteles), la "equivalencia" (de la que hablaba Tomás de Aquino), la "concordia" (de la que también habló Aristóteles) son ideales por los que vale la pena luchar.

Pero a pesar del cuadro desolador planteado unas línea antes, se han conseguido algunos logros históricos universales: la desaparición relativa de la esclavitud, la desaparición relativa del racismo y el apartheid...; claro que todavía nos azota la excesiva riqueza de unos pocos [aunque por ejemplo en Colombia, hoy, ya no somos "campeones" en desigualdad; Colombia no aparece de $6^{\circ}$ país del mundo en desigualdad ni $2^{\circ}$ en Latinoamérica, pues la pobreza cayó $1.4 \%$ respecto al año anterior y en los últimos tiempos descendió 4.5\%; el ingreso de las personas más pobres mejoró (2013, abril 19)]. Esto debería animar a seguir bregando por la igualdad aproximada pues ella es posible al menos en ciertos planos.

Igualdad y desigualdad son, de ese modo, como elementos de una dialéctica permanente; alrededor de ellas existe una constante zozobra, pero que quede constancia que los logros en materia de igualdad son reales y por lo tanto es un insumo innegable de la justicia.

\section{D.3. EL MEDIO AMBIENTE}

"La ecología da cuerpo a una preocupación ética que afecta también a todos los saberes, poderes e instituciones: ¿en qué medida colabora cada uno en la salvaguarda de la naturaleza amenazada?

(Leonardo Boff)

El medio ambiente se corresponde con los derechos de tercera generación, los más recientes derechos promulgados por las Declaraciones de derechos humanos, después de los derechos que tienen por meollo la libertad y la igualdad. El medio ambiente es la matriz de estos derechos de tercera generación.

Lo justo -siguiendo nuestro hilo conductor- respecto al medio ambiente es el respeto de la ecología en todas sus formas.

Al comienzo de la Modernidad racionalista se sostuvo que la tierra era una "res extensa", ilimitada, inagotable, con la que se podía hacer todo lo que se quisiera para el aprovechamiento del hombre; al fin y al cabo lo único 
que interesaba en la Modernidad racionalista era la razón, y ésta en cuanto científica, y no la naturaleza en sí misma considerada.

Hubo en la Modernidad una fractura con el pasado, el antiguo y el medieval, los cuales sostuvieron la sacralidad de la tierra; dice Ernesto Sábato que "El fundamento del mundo feudal era la tierra", en cambio, con el Renacimiento, "la característica de la nueva sociedad es la cantidad", dándose así un reemplazo de la metafísica por el diablo (Hombres y engranajes, p. 23).

Pero, hecho el devastamiento de gaia, de la madre tierra, de la casa común de los hombres, fruto especialmente de la industrialización y del capitalismo voraz, se ha llegado a comprender que gaia no es infinita, que nuestra casa común es "limitada", que la idea modernista de la tierra como res extensa fue equivocada, que podemos perecer muy fácilmente si no reaccionamos ya a salvarla (a este respecto recomendamos vivamente el documental de Al Gore denominado "Una verdad incómoda"); a la tierra la vemos amenazada por obra de esos grandes depredadores que son el capitalismo, el consumismo, el imperialismo político, el CO2 [precisamente el día 11 de mayo de 2013, la prensa registró el más alto índice de este gas hasta ahora en la tierra: "El nivel de dióxido de carbono $(\mathrm{CO} 2)$ en la atmósfera de la tierra superó por primera vez las 400 partes por millón (ppm), lo que muestra un nivel record de gases de efecto invernadero, aseguró ayer la Administración Nacional Oceánica Atmosférica de Estados Unidos (NOAA, por su sigla en inglés"), 2013, mayo 11].

La ecología es el payaso de Kierkegaard que viene a gritar, hoy, dramáticamente, que el "circo" (la tierra) se está quemando.

Pero... ¿qué es la ecología? Siguiendo a su fundador, Ernst Haekel (18341919), “es el estudio de la inter-retro-relación que todos los sistemas, vivos y no vivos, tienen entre sí, y con su medio ambiente respectivo" (Boff, 2008a, p. 103).

Nosotros añadiríamos que la ecología también es "proyectiva", es decir, la ecología no mira solo hacia atrás y al presente sino también al futuro-como pareciera circunscribirla Haekel-, a las próximas generaciones humanas y no humanas.

Ahora bien, la ecología no se ha restringido a "lo verde" sino que es una "crítica radical" al mal modo humano de tratar a la naturaleza; en este sentido dice Leonardo Boff: "A partir de esta preocupación ética de responsabilidad y solicitud para con la creación, la ecología abandonó su primer estadio (el 
que adoptaba la forma de 'movimiento verde' o de protección y conservación de especies en extinción) para transformarse en una crítica radical del tipo de civilización que construimos" (p. 105). Yo corregiría lo anterior diciendo que la ecología no ha abandonado nada de lo primero, sino que lo conserva, desde luego añadiendo lo segundo, es decir, su crítica radical al mal modo humano de comportarse hoy en día con el "planeta azul".

De esa pequeña noción de ecología se puede deducir, además, la relación de ésta con la llamada "complejidad", con la llamada "teoría del caos", es decir, podemos afirmar que la ecología es transversal, es holística, configura una comunidad biótica y no biótica; en suma, es fundamental para la subsistencia de los seres humanos y no humanos en relación mutua.

Desgraciadamente esa comunidad de seres en la tierra y fuera de ella se ha visto violada por factores economicistas, materialistas, de interés, de poder, de irracionalidad, y de falta de afectividad, y hemos llegado de esa manera a lo que se ha denominado el "calentamiento global", el "efecto invernadero" (desde luego hay excepciones, como en general las comunidades indígenas que se interrelacionan íntimamente con la naturaleza, y, por qué no decirlo justamente, los ecologistas).

En ese desbarajuste de la naturaleza y su comunidad ecológica se observan desniveles tales como que el $18 \%$ posee el $80 \%$ de la tierra; que los tres más grandes ricos tienen lo que tienen 48 países pobres; que un $83 \%$ de la tierra ha sido ocupada y devastada por los hombres, que la capacidad de la tierra está excedida en un $25 \%$ de lo que la tierra puede dar... (2008b, pp. 112,113).

Antes tantas amenazas a gaia, debemos recurrir, pues, a la ecología, a un pensamiento poliédrico, de diálogo, de varias perspectivas, donde haya diversas expresiones ecológicas: ambiental, política y social, mental, e integral.

¿Qué son esas ecologías?

Siguiendo en esta materia igualmente a Leonardo Boff quien es para nosotros paradigmático y proverbial en el tema (pp. 101 y ss.), podemos ver lo siguiente:

- La ecología ambiental o comunidad de vida lleva a "entender que las rocas, los ríos, los océanos, los distintos climas, las plantas, los animales y los seres humanos, no están simplemente yuxtapuestos el uno al lado del otro, sino que todos ellos se encuentran interconectados entre sí, formando la comunidad biótica, un gran sistema que se autoregula a sí mismo" (p. 107). 
Desde luego esta ha sido la ecología a la cual se ha reducido muchas veces la misma ecología; pero debemos trascenderla con las otras que a continuación se exponen.

- La ecología política y social lleva a preguntarse "cómo utiliza los recursos y servicios naturales, cuál es su modo de producción y sus pautas de consumo, de qué manera los ciudadanos participan o no de los beneficios naturales y culturales, cómo trata a los residuos, qué hace para darle descanso a la tierra y cómo garantiza la regeneración de los recursos escasos a objeto de asegurar el futuro para sí y para las generaciones que seguirán a la nuestra" (p. 111).

En suma, dice Boff, "es preciso otro modelo de civilización. Más que de un crecimiento y desarrollo sostenible, de lo que tenemos necesidad es de una Tierra sostenible, de una naturaleza sostenible, de una vidas humanas sostenibles y, especialmente, de una sociedad ecológicamente sostenible..." (p. 116).

Tratándose de nuestro país, Colombia, la ecología socio-política en cuanto a lo minero se encuentra en un estado que no podemos dejar de juzgar de muy grave; podemos verlo en la crítica que le hace Luis Jorge Garay al estado de cosas actual de ese sector; se trata, dice, de un modelo puramente extractivista, con técnicas discutibles en términos ambientales, con desgobernanza del Estado (no así con los hidrocarburos), sin regulación rigurosa en lo tributario, ambiental, y social, con altos índices de desplazamiento, despojo y abandono de tierras en pro de los que obtienen licencias mineras, presencia de grupos que suplantan al Estado, todo lo cual es denominado por Garay como minería criminal (2013, mayo 12).

- La ecología mental, que requiere de nuevas mentes y nuevos corazones, la más difícil de conseguir según Boff; implica "un cambio de mente y de corazón... un nuevo sentimiento de interdependencia global y de responsabilidad universal" (p. 118), que supere "escollos" como la inconsciencia y la ignorancia acerca de los estragos que hacemos con la tierra, el antropocentrismo, el racionalismo y la falta de compasión con la tierra, el individualismo cultural, la competitividad, y, el consumismo (pp. 118-120).

Frente a esos escollos las soluciones serían: desarrollar una gran sensibilidad para con la naturaleza, brindar cuidados esenciales para 
con la vida especialmente a su comienzo y a su final, asumir nuestra responsabilidad universal, dar prioridad a la cooperación y a la solidaridad por encima de la competitividad, y cultivar la espiritualidad.

- Finalmente, Boff habla de la ecología integral, por la cual "percibimos la importancia de integrar la Tierra y al ser humano con el Todo y descubrir la conexiones que ligan y re-ligan a todos los seres, la materia y la vida, el espíritu y el mundo, Dios y el universo" (p. 125); Boff, en su obra mencionada, dice que el hombre posee el denominado "punto Dios" en el cerebro de que hablan los neurolingüistas y neurólogos (cfr. p. 187)].

Llegados a este momento, ¿Leonardo Boff no muestra, para el propósito trazado en este libro, la necesidad de un punto medio ecológico, que no aparece explícito en Boff, sino deducido por nosotros de él? ¿No se trata de una suma de factores ecológicos, en vez de negativos reduccionismos mercantilistas y mecanicistas en dicha materia?

D.4. AlgunOS APORTES PARA UNA IUSFILOSOFÍA SOCIAL.

"Los pobres son nuestros dueños y nosotros somos sus servidores"

(Federico Ozanam).

Lo atrás tratado de libertad e igualdad, se encuentra ubicado en los dos primeros ideales del liberalismo político; queda por tratar en estas reflexiones del ideal de la fraternidad, de cuño cristiano, y recogido por el liberalismo político [el iluminismo jurídico, las Declaraciones de derechos del hombre liberales, y la Ley fundamental alemana, por ejemplo, se inspiran en las convicciones del cristianismo (Benedicto XVI, 2011)].

Hasta ahora la filosofía del derecho ha recorrido caminos desde luego importantes: buscar el origen más profundo del derecho (la naturaleza humana, la norma estatal), buscar valores y finalidades del derecho (la paz, la justicia...); pero, en esta época, donde ciertamente ha habido progresos de todo tipo (político, económico, social, tecnológico, científico...), sigue lacerando a la humanidad una gran desigualdad entre los hombres, una gran inequidad, social, mundial, pero que se mantiene en niveles lamentables, que deberían hacer pensar en replanteamientos de todo tipo y también de la misma filosofía del derecho para que desde ella se haga su aporte pertinente: podríamos denominarla filosofía del derecho social. 
Existe un mundo rico económicamente, bien sea por propios talentos, por una tierra fértil, o por lo que sea (Estados Unidos, Alemania, China, Japón...), y un mundo pobre, debido a desgracias naturales, inferioridades mentales ante el destino, o por lo que fuere (varios países de África, varios países de Latinoamérica...); hay quienes tienen una acumulación de riqueza fantástica (petroleros...), o mal habida (narcotraficantes, mafiosos), y quienes no tienen nada por una propia mala decisión (indigentes, habitantes de la calle, drogadictos...)...; pero lo cierto, es que nos ha correspondido vivir en una tierra común y en una comunidad global, en una familia humana, con un mismo destino general, y también inter-generacionalmente (viejos, adultos, jóvenes), y debemos ser solidarios unos con otros: he ahí el fundamento o referente para una iusfilosofía social.

Cerca de mil millones de personas en la tierra padecen hambre física (hoy vamos por más de siete mil millones de personas en el mundo); miles de niños son utilizados por sus padres para conmover y así obtener recursos bien sea por necesidad o por negocio; muchos niños trabajan en minas porque necesitan el comida; el desempleo cunde en muchas partes del mundo, la tecnología ha reemplazado la mano de obra humana, no hay oportunidades laborales; la educación y la cultura no llega todos, y menos aún, la sabiduría, aplastada por obra del exceso de información y la agitación del mundo de hoy; las enfermedades no son suficientemente atendidas y sanadas tal vez por los costos elevados o por las distancias físicas entre el mundo rural y el mundo urbano; la prostitución por necesidad o por trata de mujeres se expande como un negocio inhumano y sumamente lucrativo; muchos no viven sólo en pobreza sino más aún, en miseria material y psicológica; hay miles de personas sufriendo desplazamiento de sus tierras debido a la violencia político-económica donde intereses ideológicos, territoriales y de dinero, priman sobre la dignidad de la persona humana; minorías, como los afrodescendientes y los indígenas, se encuentran en situaciones deprimentes desde hace siglos a pesar de las declaraciones jurídicas que defienden sus derechos; hay muchísima explotación sexual de niños en prostíbulos y a través de la pornografía no obstante que se afirma que los derechos de los niños prevalecen sobre los de los demás; en muchas partes se desperdicia la comida con tal de no perder jugosas ganancias a pesar de que hay gentes y países con verdaderas hambrunas; los poderosos del mundo son indolentes y sólo desean acrecentar su riqueza sin pensar en los necesitados; los dependientes absolutos de las drogas a causa del sin sentido de la vida aumentan encontrándose en situación de alienación mental y social absoluta; existen regímenes políticos 
autoritarios que tiranizan a sus súbditos quitándoles su libertad pues para ellos prevalece lo ideológico político sobre el ser del hombre...

En fin, son muchas las dolencias del hombre en medio de un mundo desarrollado en múltiples aspectos pero donde la ética individual y colectiva se encuentra deprimida.

¿Vale la pena lanzar el anterior cuadro? ¿No es la misma situación, o similar, a la de toda la historia de la humanidad pareciendo que la pobreza es inevitable? ¿Pero... no es posible una sensibilidad histórica ahora, nueva, real, eficaz?

Creemos en esto último, pues nos resistimos a ser sujetos pasivos de la historia y por ello vale la pena una nueva filosofía del derecho con un fuerte carácter social, sin que ello suponga sacrificar la visión de conjunto, integral, universal, propia de la filosofía.

No por centrar esfuerzos en el pobre se puede descuidar la mirada general a la sociedad; si se descuida esa visión del conjunto social, podría suceder lo dicho por García Márquez de Hugo Chávez en 1999: “Creó nuevos programas de salud, alimentos baratos y educación para los más pobres, pero no dio respuesta al crecimiento alarmante del crimen y la corrupción. Marginó a la clase media, a los emprendedores y a sus críticos, pero dio visibilidad a los excluidos" (2013, marzo 6).

Y a propósito de necesitados, ¿cómo "llamarlos" de pronto más adecuadamente?: ¿excluidos, marginados, pobres...? Aquí podríamos detenernos un poco pero quizá no sea sino un distractor ante la urgencia de abordar la pobreza. Debemos decir, sí, que no se trata sólo del pobre "material"; también hay que atender a los "pobres psicológicos", o del alma, o espirituales, a todo aquél que, en palabras de FoucAult, padece la opresión de los micropoderes sociopolíticos, y por qué no decir, también los pobres que sufren la dominación de los macropoderes sociopolíticos también.

Esta iusfilosofía social mira a lo que podríamos denominar un derecho básico, primario, natural, más que a un derecho que podría llamarse "secundario", el propio o proveniente de sentencias judiciales; por eso, esta iusfilosofía social tiene un gran componente "político-ejecutivo", está primariamente en esa esfera de las obligaciones y realizaciones del poder político; en este sentido la filosofía del derecho social se ubica más exactamente en el concepto que debe dar "legitimidad del Estado", más que en el de la validez del derecho, y por supuesto se ubica también en el terreno de la eficacia social del Estado y del derecho. 
Hoy en día existe una sensibilidad por los pobres a nivel, por ejemplo, de la Conferencia, Cumbre o Foro de Porto Alegre en Brasil; eso está bien; claro, al hablar de Porto Alegre, enseguida surge la posible circunscripción de esa vocería en pro del pobre en la "izquierda"; pero, si no se es izquierdista adscrito, en todo caso deberíamos decir, con Tomás de Aquino, que la verdad es verdad venga de donde venga; ahora, en realidad esa preocupación no es "sólo" de la izquierda política; la Doctrina Social de la Iglesia Católica viene empujando el tema de una mayor justicia social desde 1891, hace, por tanto, ya más de 120 años, desde la encíclica social Rerum Novarum del papa León XIII, prosiguiendo con otras hasta nuestros días; y en el seno de la Iglesia Católica también, se ha abierto paso con gran fuerza, la llamada "Teología de la Liberación", desde mediados del siglo XX, con una fuerza originaria especial en Latinoamérica.

Pero volviendo a la izquierda, gobiernos socialistas en Latinoamérica han ido ganando espacio, como reacción ante gobiernos corruptos, perpetuadores de clases dominantes, e ineficientes, de la región latinoamericana, aunque con diferentes ideologías de fondo y resultados distintos.

De otro lado, premios Nobel de Economía como Joseph Stiglitz, alza su voz también a favor de la equidad.

El denominado "neoconstitucionalismo" es también de direccionamiento social, a partir de 1920: es un derecho más social y real que formal.

Además, teóricos de la iusfilosofía recientes y contemporáneos de gran renombre, insisten en esta visión social; así por ejemplo, John Rawls habla de una justicia distributiva de los "bienes primarios" operada desde las instituciones (Sen, 2010); Sen mismo habla a su turno de las realizaciones o comportamientos reales de los ciudadanos de a pie, sobre todo, más que de las instituciones mismas (p. 39); también de la necesidad de entender la naturaleza y las fuentes de la pobreza, tarea esencial para eliminar las injusticias notorias, identificables mediante el razonamiento público y un buen acuerdo así sea parcial (p. 292); Ronald Dworkin entra en este elenco social al hablar de la igualdad de recursos mediante el mercado de seguros (p. 294).

Amartya Sen también habla de la necesidad de la democracia en este tema de la lucha contra la pobreza cuando al tratar de la hambruna afirma que ésta se ha combatido mucho más y mejor en donde existe la democracia; así por ejemplo, ha hecho mucho más contra la hambruna la India que China o Corea del Norte, todo porque donde hay democracia, oposición, crítica, 
información transparente, prensa libre, partidos políticos en el gobierno y en la oposición, es más fácil tomar buenas medidas contra la hambruna.

No sobra un recorderis: la sensibilidad social hoy tan puesta de relieve como acabamos de hacer ver, tiene unos antecedentes históricos importantes: los "socialismos utópicos" de fines del siglo XVII y principios del siglo XVIII (Saint-Simon, Fourier, Owen, Proudhon), y el llamado "catolicismo social”, del siglo XIX, cuya figura más sobresaliente fue Federico Ozanam (Touchard, 1961, pp. 420 y ss.). Ellos empezaron, cada uno por caminos muy distintos, a empujar esta conciencia social que hoy en día nos ocupa.

En estos tiempos también aparece la sensibilidad por los pobres con la llamada responsabilidad social de las empresas, a veces meramente formal, pero de lo cual no se pueden juzgar intenciones, aunque sí realizaciones. ¿Esa responsabilidad social debe elevarse a la categoría de exigencia legal o debe seguir siendo una actitud meramente de good will empresarial o de sola sensibilidad social?

Finalmente, por citar otro ejemplo, organismos internacionales, el primero de ellos, la ONU, ha fijado los llamados "objetivos del milenio", que apuntan también a la lucha contra la pobreza: más educación básica, más y mejor salud, control de la natalidad, más justicia...

Todo un arsenal por la sensibilidad social que debe ser aprovechado.

Como se ve, se trataría de una iusfilosofía social existencialista, más centrada en el aquí y en el ahora, que en lo a-temporal y con gran dosis teórica como cuando se discute sobre si el origen del derecho es la naturaleza humana, la norma estatal, o el valor del derecho es el orden, la paz, la justicia, temas académicos pero muchas veces desencarnados de la realidad social.

Es la hora de pasar, pues, de una iusfilosofía centrada en la naturaleza humana (propia de la escuela del derecho natural) -por importante que sea-, o centrada en la norma jurídica (como lo afirmara Hans Kelsen), o apuntalada en el hombre histórico en general (Arthur Kufmann, aunque este iusfilósofo nos pone ya en la mira de lo social como ninguno otro de nuestros días), pasar digo a una iusfilosofía que mire al pobre más privilegiadamente aunque no exclusivamente. Se trataría de una iusfilosofía que propende por un derecho realidad más que un derecho ciencia, que es a lo que se miró ante todo con la iusfilosofía desde la Modernidad racionalista.

Una iusfilosofía social, desde luego tiene que echar mano de otros brazos distintos a ella misma aunque relacionados con ella: me refiero, en primer lugar, a los brazos del Estado y de la Economía. 
El modelo de Estado y el modelo económico, van de la mano con una iusfilosofía social; claro está que a este respecto no existe una fórmula totalmente ideal; dentro del epíteto "socialista", sabemos, existen diversos submodelos: no es igual el modelo socialista de Hugo Chávez Frías en Venezuela, hasta ahora con muchos lunares, que el modelo socialista de Lula da Silva en Brasil, con resultados muy positivos: el primero, el venezolano, es más notoriamente estatalista, colectivista, y el segundo más propenso a un cierto capitalismo aunque fuertemente regulado por el Estado. Lo mejor a nuestro juicio es que cada país siga su propio camino; los “clones" en estas materias, y en cualesquiera otras, siempre resultan inadecuados. Los socialismo nórdicos funcionan muy bien en esos países: Noruega, Finlandia, Dinamarca, Suecia... y no tienen por qué seguirse a pie juntillas por otras naciones.

Empero, lo que aquí se quiere resaltar, es que la filosofía del derecho social no puede ser un discurso isla, autosuficiente, quizá arrogante, sino que debe ir conjuntado con un tipo de Estado, de fuerte carácter social, y un tipo de economía de libre empresa pero regulado por el Estado con normas precisas y eficaces. Derecho social, Estado social, Economía social, forman una tríada inseparable y, a la vez, constructiva.

Un sub-brazo del Estado es también, por ejemplo, la Corte Constitucional (llámese como se llame en cada país), con tareas eminentemente sociales, desarrollando el llamado Estado social de derecho; así se ha visto, por poner un caso, en Colombia, con las exigencias de dicha Corte Constitucional al Ejecutivo para atender a los desplazados por la violencia político-económica.

Y el derecho, a su vez, con amplio sentido social, sale al paso de los necesitados con instrumentos concretos y vivos: existen principios e instrumentos jurídicos para mirar más al pobre: así por ejemplo la Constitución Política colombiana de 1991 en su artículo 1 dice que Colombia está fundada en la solidaridad; y en el art. 95 se habla del deber, obligación y responsabilidad de todos los ciudadanos de "Obrar conforme al principio de solidaridad social, respondiendo con acciones humanitarias ante situaciones que pongan en peligro la vida o la salud de las personas"; asimismo en el numeral 4 del mismo art. 95 se dice que es igualmente un deber defender los derechos humanos. La acción de tutela, las acciones de grupo, las acciones populares, son entre otros, instrumentos concretos a favor de los pobres.

Derecho, Estado, Economía, conjugados, mancomunados, pueden así, más fácilmente, acceder al viejo fin y anhelo denominado "bien común", esto es, ese conjunto de condiciones sociales, que ayuda a los individuos, a las 
familias y a las asociaciones, a llegar a su plenitud de manera más expedita (Concilio Vaticano II, 1962-1965).

A los "afortunados" económicos y sociales del mundo casi podría decirse que les basta su fortuna para proteger sus derechos: sus recursos monetarios -lo económico-, abastecen su derecho a la salud, a la educación, al ocio y la recreación, el acceso al trabajo o al menos a un capital (que debe trabajar), a un más libre desarrollo de su personalidad, a un medio ambiente mejor por poseer tierras, a la libertad, a la propiedad, etc.; pero a los pobres hay que subsidiarlos o asistirlos según sea el caso.

El Estado mismo llega a ser a veces para los ricos una parcela de sus derechos e intereses; sabemos que el Estado para los potentados se ha convertido muchas veces en una prolongación de sus posesiones; en muchas partes los ricos se han apoderado del Estado como quien extiende los límites territoriales de sus fincas o haciendas. La Economía igualmente, la macro y la microeconomía, pareciera estar echa a su medida, no los sobrepasan.

Pero a los desafortunados económicos y sociales del mundo, en cambio, el derecho, el Estado y la economía deben salir proactivamente en su ayuda; Derecho, Estado y Economía co-existen para ayudar al necesitado, ayuda que puede ser asistencialista o paternalista, en muchos casos, no se puede negar (por ejemplo, a un paralítico que no puede trabajar, a un drogadicto que necesita una ayuda psicológica, etc.), aunque también, y prioritariamente, una ayuda regida bajo el "principio de subsidiaridad": no haga el Estado o la autoridad de que se trate, lo que el necesitado puede y debe hacer por sí mismo, porque precisamente puede o tiene capacidades; es lo mismo que contiene el mensaje aquel de que no hay que darle el pobre un pescado sino ayudarle a pescar.

¿Con qué "medios" lograr esta sensibilidad? El grito, el reclamo, la no violencia, el proceso gradual, progresivo, parecen, a mi juicio, más convenientes.

No quiero ignorar, desconociendo la teoría política de Tomás de Aquino, de Locke, y otros, la revolución cruenta, la insurrección, la sublevación, cuando se llega a un extremo imposible; pero considero que el medio de la no violencia es más humano y eficaz.

La violencia es más cruenta muchas veces que la misma pobreza, y sus frutos no han sido muchas veces los mejores ni los más duraderos; y ¿no han llegado al poder, más bien, los socialismos democráticos, impulsando 
sus programas, como en Venezuela, Ecuador, Brasil, Chile, Argentina? Claro está que existe el peligro de una instalación en el poder por mucho tiempo, corriéndose el peligro de engolosinarse con el poder político y aun económico, cuyo sucedáneo, sabemos, es la corrupción; el poder muchas veces corrompe: lo ha demostrado la historia de la humanidad.

Tarea importante, como vimos que anota Sen, es la de identificar el origen de la pobreza; pareciera que un punto de mira ineludible y raizal es la ambición humana, la mala voluntad humana; a este respecto entonces, el centro a mirar es el corazón del hombre, tarea que le corresponde abordar a la ética y a la educación, antes que a las leyes; de esta manera, no basta decir lo dicho arriba: que los brazos de la iusfilosofía son el derecho, o el Estado, o la Economía: antes que ellos están los brazos de la ética y la educación.

Ya el gran Aristóteles ataba el derecho y la política a la ética; basta corroborarlo con la lectura de sus obras "Ética a Nicómaco", y, la "Política". Así las cosas, la iusfilosofía en esta materia social, en este clamar en favor de los pobres, no es sino un fragmento de una empresa multifactorial: derecho, economía, política, ética y educación.

No sobra decir aquí que debe hacerse una distinción a nuestro juicio importante: la del pobre y la del miserable; el pobre tiene valores de los que hay que aprender (así lo sostiene por ejemplo Federico Carrasquilla); otra cosa es la miseria, que es degradación humana y de la que no hay nada que aprender, pero que no por ello hay que desatender. El nombrado Carrasquilla, en su libro 'Escuchemos a los pobres' (pp. 58 y ss.), caracteriza al mundo pobre con valores como su sentido de gratuidad y de fiesta; de aceptación de la realidad; de sentido del otro (y de ese Otro que es Dios); de obstinación, $\mathrm{y}$, de sentido de lo concreto y de lo inmediato.

No sobra recalcar aquí que "en Colombia" ha habido autores con esa conciencia filosófica social: Eduardo Umaña Luna (Urgencia de un derecho social, 1967, comunicación hecha a Orlando Fals Borda); Orlando Fals Borda (La subversión en Colombia; Hacia el socialismo raizal y otros escritos, 2007), Darío Botero Uribe, Rodrigo Uprimny, Oscar Mejía Quintana, Rodolfo Arango Rivadeneira, y otros más cuya lista sería larga; son filósofos del derecho y sociólogos; de todos ellos cabe aprender aspectos para esta filosofía del derecho social.

Y otro tanto cabe decir en "Hispanoamérica": Leonardo Boff(vgr. Ecología: grito de la tierra, grito de los pobres; La opción tierra); Jorge Carpio-Irene, 
De igual a igual. El desafio del Estado ante los nuevos problemas sociales; Peter Smith, La democracia en América Latina; Elisabetta Di Castro, Paulette Dieterlen, Debates sobre justicia distributiva, entre muchos.

\section{$* * *$ \\ E. LA HERRAMIENTA CONCRETA DE LA POLÍTICA. OTRA VENTANA.}

“...pues el pueblo está tranquilo cuando puede participar en el poder soberano"

(Aristóteles).

Pasemos ahora a ver el brazo de la política como un instrumento más, junto con el derecho, para alcanzar la justicia general.

Para empezar cabría preguntarse si existe una noción de justicia para el campo político; creemos que sí, y es la de que lo justo político consiste es buscar y conseguir el bien común -lo que se sintetiza en ocasiones en la expresión "legitimidad" política-, noción de vieja raigambre y general aceptación.

Pero... ¿y qué es el bien común? ¿Qué es la legitimidad política?

Consideramos que es la sumatoria equilibrada de derechos y de obligaciones en las personas (difícil en un mundo donde se privilegian los derechos en detrimento de los deberes), de lo privado y de lo público, y de lo local y lo global. Ese bien común, ese justo político, es nuestro eje conductor en materia de justicia política.

Ese bien común es el meollo de la justicia política... ¿lo han conseguido regímenes políticos como el absolutismo (que postula un Estado soberano en manos del monarca absoluto sin consideración del individuo), el totalitarismo (que postula que sólo el Estado y su jefe carismático gobiernan al pueblo marginando a la persona humana), las dictaduras (que se asientan en que sólo el dictador de turno maneja los hilos del Estado), la aristocracia (que postula que sólo unos cuantos selectos ante todo en la forma de oligarquía gobiernan la política y la economía del Estado)? Parece que no, al menos en comparación con la democracia. Adela Cortina afirma a este respecto:

"Al menos desde Hipódamo de Mileto, a mediados del siglo V antes de Cristo, el gran reto de la filosofía política había venido consistiendo en determinar cuál es el régimen político más perfecto. Monarquía, aristocracia, democracia, 
tiranía y oligarquía entraron en un debate que duró siglos. Sin embargo, esta cuestión perdió su mordiente a mediados del siglo pasado, cuando la dolorosa experiencia de los totalitarismos de distinto cuño condujo a un amplio consenso sobre la superioridad de la democracia frente a cualquier otra forma conocida de gobierno" (Cortina, 2010, pp. 9,10).

En realidad de verdad la discusión actual no versa sobre los tradicionales regímenes antiguos de monarquía, aristocracia y democracia; la discusión se limitó de hace un tiempo para acá a sola la democracia por la caída de los totalitarismos de Estado (hacia 1990), aunque es de observarse que la democracia debe ser constantemente atendida, revisada y custodiada para que no decaiga, a pesar de sus bondades.

Y... ¿qué es la democracia desde el punto de vista de lo justo?

Nosotros consideramos que la democracia lo es, en tanto en cuanto se centre en el valor de la persona humana (no del Estado en sí, ni siquiera de los mecanismos formales democráticos en sí, por valiosos que todos ellos sean); la democracia, para que sea justa, debe estar al servicio de la persona, de sus derechos fundamentales, aunque no individualísticamente sino en el equilibrio de sus derechos y obligaciones.

Más allá de las estructuras propias de la democracia, como la división de las ramas del poder público, las elecciones, etc. -que desde luego son mecanismos necesarios e inherentes a la democracia-, lo que hace que la democracia sea eso desde el punto de vista más medularmente justo y ético, es lo dicho, esto es, el profundo respeto por la persona en sus derechos básicos.

Ahora bien, también es verdad ética que esa persona, a su vez, debe "devolver" a su sistema protector democrático lo mejor de sí, tiene obligaciones también para con él: es, por lo tanto, un camino de "ida" y "vuelta" entre sistema y persona, persona y sistema. Es lo que Aristóteles llama la justicia legal. Coincidimos en esta materia con Amartya Sen cuando afirma que la visión "institucionalista" democrática, que ha sido la tradicional en Occidente, debe ser revisada y superada en el sentido de que, sin demeritar lo "institucional", hay que dar mayor cabida a los "comportamientos reales de las personas" en pos de la justicia.

Adela Cortina, además, en el mencionado escrito "Las raíces éticas de la democracia" (pp. 10 y ss.), ha tratado de mostrar que la democracia es un sistema político "ético" -podríamos decir "justo" para tratar de seguir el hilo de nuestro discurso-, por tres razones: 
a. Ser un sistema de contrapesos en el poder político que sirve para atajar los totalitarismos y tiranías.

b. Ser un sistema político de ciudadanos, no de masas.

c. Ser un sistema político donde la ley y sus autores refleja el querer de los ciudadanos.

Donde Cortina más se detiene de estos factores éticos de la democracia es en el segundo; es ahí donde ella encuentra el mayor grado de eticidad-justicia de la democracia; el primero de ellos -el sistema de contrapesos- no deja de ser un mecanismo, una estructura, desde luego importante como muralla contra los excesos del tirano; pero en el escrito mencionado Cortina no lo aborda en extenso; es como si quisiera mostrar que ahí no radica el mayor fondo ético -justo- de la democracia, aunque no se puede prescindir de él.

Empieza Cortina recordando a Kant, para quien la educación de la persona lleva a ésta a ser persona: "Sólo por la educación el hombre llega a serlo" (La raíces éticas de la democracia, p. 8; personalmente no estoy totalmente de acuerdo con este pensamiento de Kant; el hombre es hombre por tener una dignidad innata; de aceptar acríticamente el postulado de Kant, un incapaz por diversos motivos no sería hombre por el hecho de no poder educarse; podemos aceptar solo parcialmente esta idea en tanto en cuanto podemos crecer intelectual y laboralmente, sí, con la educación, pero solo a posteriori de la dignidad innata de todo ser humano); prosigue Cortina con la diferencia entre Weber y Arendt en materia política: para Weber la política estatal monopoliza la violencia legítima, mientras que para Arendt la violencia es pre-política en tanto que la política consiste en el poder comunicativo (Cortina, 2010, p. 14).

Con estas bases, Adela Cortina va a desarrollar la democracia ciudadana, la democracia de ciudadanos, sinónimo de hombres educados y comunicativos desde los cuales se puede hacer la ley positiva jurídica.

Lleva después la filósofa Cortina (2010,p. 16) a dos pensadores políticos de renombre: Benjamin Constant y Joseph Schumpeter; recuerda que Constant diferenció la libertad en dos clases: la antigua, donde todo se centraba en la vida pública, y la moderna donde existe más atención por la independencia privada (familia, amistad, economía); desde luego, dice Constant, no puede haber, a pesar de la diferencia, divorcio total entre una y otra libertad, sino que debe haber conexión entre ellas, al punto que desde la libertad privada se elige a algunos para que representen a las personas en la política; el punto 
a tener en cuenta es que el cómodo ciudadano libre que estima en mucho la independencia privada debe seguir teniendo en cuenta, como haciéndole un seguimiento a su tarea política, a sus representantes políticos que lo representan en los órganos de poder.

Schumpeter, por su parte -sigue recordando Cortina-, diferencia entre "democracia clásica" y "democracia real"; la primera se funda, según él, en conceptos etéreos como el "bien común" y la "soberanía popular"; la soberanía popular no existe sino que existen intereses particulares, y el bien común tampoco existe sino que existen intereses en conflicto; ¿qué queda? Dice Schumpeter que queda lo real, con lo que se debe contar en política: pluralismo político, caudillaje, apatía del pueblo, castigo a las élites que no cumplan promesas, economía como motor de la vida política...

Y dice Cortina -siguiendo a Sartori-, que en medio de esa barahúnda real schumpeteriana y constantiana reaparece con más fuerza la pregunta acerca de cómo gobierna el pueblo, cómo se forman las mayorías (donde ya no se trata de la democracia "directa" de Grecia sino de la democracia "representativa" moderna).

Aquí es donde aparece el aporte específico de Cortina en materia éticopolítica-democrática; en efecto, ella distingue tres clases de mecanismos formadores de la mayoría del pueblo (pp. 26 y ss.), a saber:

1.- El mecanismo emotivista, sentimental, el que se dirige a las "masas" y no al "pueblo", yéndose de esa manera contra la ética política, contra lo justo político, pues manejar masas es propiciar sujetos -siervos y esclavosheterónomos y no ciudadanos autónomos; el concepto de pueblo, por el contrario, supone educación del mismo, propiciación de sujetos autónomos, es decir, de ciudadanos, donde existe racionalidad, diálogo, amistad cívica, debate público, intercambio de opiniones, forjamiento de una voluntad común en pro de la justicia, valores todos éticos, justos, y donde dicha discusión y debate es trascendental.

2.- El mecanismo agregativo, que supone discrepancias, pluralidad, por lo cual se debe llegar a acuerdos mayoritarios; el problema de esta postura es, sigue diciendo Cortina, que el agregacionismo mantiene vivo el individualismo; dice: "La democracia agregativa, a fin de cuentas, cree contar sólo con individuos atomizados, aunque en este caso sean más racionales que en la democracia emotiva" (p. 34).

3.- Y el mecanismo comunicativo, el preferido de Cortina, el más ético y justo: "La democracia comunicativa es aquella en que los ciudadanos intentan 
forjarse una voluntad común en cuestiones de justicia básica, a través del diálogo sereno y la amistad cívica. Cuenta, pues, con pueblo, más que con masa" (p. 35).

Los "valores éticos" de este mecanismo - o democracia comunicativaserían en suma: el diálogo sereno, el debate público, el intercambio de argumentos, y la amistad cívica (como la denominaba Aristóteles).

Cortina añade a lo anterior el que en este tipo de democracia ciudadana los "partidos políticos" son capitales siempre y cuando: a) ellos sean pluralistas a su interior para contagiar a la sociedad de ese pluralismo; b) se establezca la prohibición de desacreditar, de denigrar, al rival.

Y remacha la filósofa española su discurso de las raíces éticas de la democracia diciendo también que el ciudadano debe en la democracia comunicativa educarse tanto autónomamente como solidariamente: "Porque conocemos la justicia no sólo por la razón, sino también por el corazón" (p. 41): otra idea central para nuestro discurso, que busca, como hemos dicho tantas veces atrás, sumar, dialogar, en vez de reducir o restar, ya que en este caso se suman dos elementos fundantes de la persona humana: la razón y el corazón.

Se puede ver con lo visto hasta aquí, que en resumidas cuentas lo justo político se desenvuelve más expeditamente en la democracia en tanto en cuanto este régimen es un régimen de respeto y garantía de los derechos humanos, con mecanismos que obstaculizan la tiranía de las autocracias y dictaduras como el de la división y contrapesos de las ramas del poder político, y que eleva al pueblo mediante valores que desarrollan la autonomía y la comunicación de los ciudadanos.

Empero, no nos sentimos del todo satisfechos con lo dicho hasta ahora para retratar la justicia democrática; si nos fijamos un poco más, la "ética real de los ciudadanos" no ha aparecido hasta aquí en Cortina de manera más contundente.

En este sentido no podemos dejar de hacer referencia a la "ética práctica" como catalizador de la justicia democrática, porque no basta lo anterior (los mecanismos "exteriores" podríamos decir, esto es, el sistema de pesos y contrapesos, la democracia de ciudadanos y la ley como expresión de la ciudadanía, antes vistos).

Ciertamente, como dice Amartya Sen, los derechos humanos son imperativos éticos (Sen, 2010, pp. 389-390), pero aparte de serlo, debemos proceder a cumplirlos, a "darlos", papel que corresponde a la ética práctica y 
no meramente teórica; por ello también es por lo que toda la obra de Sen en su libro mencionado, lleva a no reducir la democracia a lo "institucional", al aparato de las solas estructuras exteriores, sino que debemos proceder a los "comportamientos reales" en pro de la justicia.

Todos sabemos de sobra que de mecanismos democráticos estamos quizá llenos, repletos, abundantes, pero ellos no bastan, es menester que el comportamiento de los ciudadanos sea honesto en dirección a los valores que dice encarnar la democracia para no padecer la denuncia de peculados millonarios a diario en nuestras democracias.

Ya Hobbes - a contrario sensu- trató de las causas de la disolución de los gobiernos, $\mathrm{y}$, aunque la menciona de última, no por eso la podemos perder de vista; se refiere Hobbes a los comportamientos personales que acaban con el gobierno: al apetito insaciable de ampliar el dominio, al letargo del ocio, y al gasto vano (Hobbes, 2007, p. 283), conductas como vemos personales y perniciosas, que acaban lentamente con la gobernabilidad.

Y hablando de la democracia liberal, su padre John Locke, trata también entre las causas de disolución del gobierno democrático la fuerza, el dinero, la corrupción para corromper a los representantes (Locke, 2007, p. 213). ¿No es lo que sigue ocurriendo hoy en día en nuestras maltrechas democracias?

Si de lo positivo se trata, el ciudadano debe construir democracia entonces con su comportamiento justo, ético.

F. LA HERRAMIENTA CONCRETA DE LA ECONOMÍA. UNA VENTANA MÁS

"No obstante, también ha existido una concepción moral del capitalismo que no solo le considera capaz de producir riqueza y bienestar, sino que insiste además en su carácter moral, y esta concepción es la que se ha ido consolidando últimamente, es decir, la que propugna cada vez con más fuerza que la ética es uno de sus pilares fundamentales"

(Adela Cortina).

Finalmente veamos el brazo de la economía como insumo para alcanzar la justicia.

Así como parece existir una justicia para el derecho (la basada en la conjugación armónica de naturaleza y razón con la base común de un Spiritus Creator), y una justicia para la política (la que busca el bien común, o, si se 
quiere también la que respeta y custodia los derechos humanos), ¿cuál sería, ahora, la noción de justicia para la economía? ¿Qué es lo justo económico?

A nuestro juicio, tanto a nivel personal, familiar o estatal, la justicia económica radica en lo que Aristóteles llama la "liberalidad", esto es, “...la posición intermedia con relación a los bienes económicos" (Ética a Nicómaco, Libro IV), que se ubica entre dos extremos opuestos, la prodigalidad por un lado y la avaricia por otro. Es desconcertante esta afirmación tan sencilla y tan antigua para detectar lo justo económico, pero así lo vemos, y ahora más que nunca ante la crisis económica europea, pues los Estados económicamente son como un eco de lo que acontece en lo personal y familiar económico: y es que si no hay ahorro, cierta austeridad, previsión, por un lado, e inversión y generosidad, por otro, el Estado se va al traste económicamente hablando.

En efecto, los Estados europeos en su opulencia económica tras el éxito, en todos los terrenos, después de la "guerra fría", la falta de ahorro previsivo, la petición de crédito sin límites para seguir gastando (burbuja económica), el consumismo exagerado, cayeron en la especulación, el gasto irracional, y demás desmanes, para finalmente encontrarse en la situación actual de crisis económica.

Es lo que también le ocurre, repetimos, a las personas y a las familias con la falta de ahorro, de previsión, de austeridad; éstas, así como los Estados, por el contrario, deben ajustarse a normas de prudencia económica entre el derroche y la avaricia; es la llamada liberalidad según Aristóteles, que podemos traducirla por "punto medio económico".

En este punto de la herramienta concreta de la economía para el logro de la justicia recurriré a tres fuentes, todas ellas desde "orillas" ideológicas distintas, que pueden dar una idea al menos suficiente del tema (es decir, la justicia económica).

En primer lugar, Juan Pablo II en un escrito suyo de 1991, (ya dije atrás que se nos puede criticar el apoyarnos bibliográficamente en un Papa, pero tal prejuicio cae ante la necesidad de la tolerancia, de la complejidad y del diálogo de las distintas posiciones ideológicas); en segundo lugar recurriré a Adela Cortina, filósofa española, en un suyo escrito de 1994; y en tercer término, a Joseph Stiglitz, premio nobel de Economía en el 2001, en una obra suya de 2012. De esta manera no se nos puede tildar de hablar desde una sola posición ideológica. Y lo haremos así, cronológicamente, de más antigüedad a lo más reciente y actual. ¿Por qué traemos a colación a tres autores con posiciones distintas ante la economía? Pues porque los tres autores mencionados tratan de "lo ético" en la economía (podríamos decir 
que los tres tratan de "lo justo" en la economía, que es nuestro hilo conductor como ya hemos dicho).

a. Juan Pablo II en la Encíclica "Centesimus annus", escrita en el año de 1991 (recordando el primer documento social de la Iglesia, la Encíclica Rerum Novarum, del Papa León XIII), se pregunta:

"Volviendo a la pregunta inicial ¿se podría decir quizá que, después del fracaso del comunismo, el sistema vencedor sea el capitalismo, y que hacia él estén dirigidos los esfuerzos de los países que tratan de reconstruir su economía y su sociedad? ¿Es quizá éste el modelo que es necesario proponer a los Países del Tercer Mundo, que buscan la vía del verdadero progreso económico y civil?

La respuesta obviamente es compleja. Si por 'capitalismo' se entiende un sistema económico que reconoce el papel fundamental y positivo de la empresa, del mercado, de la propiedad privada y de la consiguiente responsabilidad para con los medios de producción, de la libre creatividad humana en el sector de la economía, la respuesta ciertamente es positiva, aunque quizá sería más apropiado hablar de 'economía de empresa', o simplemente de 'economía libre'. Pero si por 'capitalismo' se entiende un sistema en el cual la libertad, en el ámbito económico, no está encuadrada en un sólido contexto jurídico que la ponga al servicio de la libertad humana integral y la considere como una particular dimensión de la misma, cuyo centro es ético y religioso, entonces la palabra es absolutamente negativa" (No. 42).

De esta manera podemos ver según Juan Pablo que existe un capitalismo ético y otro que no lo es, uno que es justo y otro que no. Lo ético del capitalismo radicaría en: la capitalidad de la empresa, la capitalidad del mercado, la capitalidad de la propiedad privada de los medios de producción con responsabilidad, y la capitalidad de la libre creatividad humana en el ámbito económico; las anteriores capitalidades las resume este Papa en una palabra: libertad en el ámbito económico, pero encuadrada en un marco jurídico al servicio de la libertad integral cuyo centro es ético y religioso. Si pudiésemos resumir más lo anterior diríamos: el capitalismo es ético, justo, si propicia la libertad económica dentro de un orden jurídico ético-religioso.

b. Adela Cortina, a su turno, en su obra "Ética de la empresa" habla de los "correctivos éticos" que ha auto-experimentado el capitalismo; es más, Cortina parte de la base de que el capitalismo es una herramienta productora de riqueza pero "desde" una ética concreta en un momento 
determinado; Cortina advierte que el capitalismo admite su propia "transformación", más que su "legitimación”, desde distintos ángulos éticos (Cortina, 2000, pp. 56 y ss.); dichos correctivos del capitalismo -desde el capitalismo mismo-, son, muy en síntesis, los siguientes:

1.- La ética capitalista primitiva del "empresario burgués", donde se combinan el "espíritu de empresa", con afán de lucro y espíritu aventurero, y el "espíritu burgués", que busca gastar con moderación y ahorrar, trabajar con tesón, y ser sobrio, entre otros valores éticos propios de esta postura económica capitalista y que lo llevan -al capitalismo- a una especie de autoregulación ética (valores éticos predicados tanto por la escolástica española como por el calvinismo).

2.- La ética capitalista del "interés propio", interés que es el motor natural del ser humano para llevar adelante la actividad económica (con raíces en Aristóteles, en Spinoza, y, expresamente en Adam Smith), que conlleva a crear, a innovar, a asumir riesgos, y que se "controla" a su turno a través de la "mano invisible" del mercado, de una legislación justa, de los sentimientos naturales de simpatía hacia el otro.

3.- La ética capitalista del "utilitarismo" (de Bentham y John Stuart Mill, desde luego con variantes entre uno y otro), superadora del mero mercado regulador smithiano, ineficiente, que busca la utilidad, el beneficio, el bienestar de la mayoría: algo así como que si no se puede lograr el ideal de Smith de una economía equilibrada a través del mercado, al menos deberíamos contentarnos con el bien económico de la mayoría.

Desde luego esta postura tiene su propio lunar al reducirse solo a la felicidad de la mayoría, dejando excluida a la minoría (a nuestro parecer esta teoría dejó abiertas las puertas - por una cierta ingenuidad en la creencia democrática en la mayoría como factor decisivo de la política y de la economía-a posiciones extremas como el colectivismo económico o economía centralizada en el Estado, anticapitalista.

4.- El "intervencionismo del Estado" en la vida económica dentro del ámbito liberal-capitalista, quizá el correctivo histórico más acertado de la ética capitalista.

5.- La ética capitalista del "interés general basado en la elección social"; fue también una especie de correctivo al utilitarismo benthamiano "a partir" de los "intereses sociales"; la sociedad a través de determinados procesos normativos pre-establecidos, con criterios y análisis económicos 
propios, tiene ahora la última palabra para "decidir" qué le conviene más económicamente a la sociedad.

Esta postura está llamada a desarrollos hoy dado el avance organizativo y el prestigio de que goza la sociedad en los tiempos que corren. Sería cuestión de información y de determinación de la misma sociedad.

6.- La ética capitalista de la "justicia como equidad", con raíces en John Rawls, donde se habla de la búsqueda de la justicia desde dos puntos: las libertades básicas, por un lado, y la igualdad socio-económica, por otro; la segunda, la igualdad socio-económica, busca desde luego la igualdad pero, al mismo tiempo, admite la posibilidad de una cierta desigualdad, siempre que dicha desigualdad sea beneficiosa al mismo tiempo para todos; no se trata entonces de un igualitarismo al estilo colectivista sino de una igualdad "en lo posible".

7.- La ética capitalista de las "reglas del contrato constitucional" (Buchanan), superador del mero utilitarismo mayoritario, y de la mera elección social, consagrando la distribución económica "a nivel constitucional-jurídico", queriendo con ello darle un cariz de mayor seguridad y protección a dicha distribución de beneficios económicos desde la cripta del derecho constitucional.

8.- La ética capitalista de la "coordinación del mercado" (Koslowski), una "economía social de mercado" (así la llaman por ejemplo los alemanes actualmente), donde exista un "equilibrio" entre la libertad capitalista, la libre empresa, el laissez faire laissez passere, y lo social, donde lo social tiene "regulaciones éticas, políticas y jurídicas"; es una especie, a nuestro juicio, de "recolección de las teorías anteriores".

9.- La ética capitalista que se funda en los "logros y la eficacia del capitalismo democrático"; hasta ahora el capitalismo dentro de un marco democrático y un pluralismo cultural ha dado buenos frutos; esa historia debe ser tenida en cuenta como factor histórico superior moralmente frente al "colectivismo" fracasado, e incluso superior al "socialismo democrático".

10.- La ética capitalista "social y comunicacional". Jürgen Habermas ha sido el promotor número uno de un capitalismo donde prime el discurso, la comunicación, en el que se dé prioridad al "control democrático de los afectados". No prevalecería lo "técnico-funcional" ni lo "administrativoburocrático", sino lo comunicativo, lo dialógico, y ello en la empresa como célula económica, en el ámbito de cada país, así como en un mundo globalmente considerado. 
Como se ve, existe todo un arsenal de medidas éticas en busca de lo justo económico reseñadas por Adela Cortina al interior del capitalismo, sistema económico que ha dominado los últimos tres siglos el espectro universal (salvo algunas excepciones). Es posible, entonces, una justicia dentro de este sistema, o mejor aún, unas justicias, que nosotros hemos sintetizado en la justicia como liberalidad económica aristotélica, esto es, el equilibrio, el balance entre el gasto y el ahorro, buscando con ello aproximarse a la justicia general desde el ámbito económico.

c. Finalmente, Joseph Stiglitz, en "El precio de la desigualdad" (2012), habla sobre eficiencia y "equidad", lo cual de por sí contiene un aspecto "ético" (valga decir "justo") de la economía. Sinteticémoslo:

Stiglitz parte de si el "mercado" es condenable per se: dice que no, que todo lo negativo de la economía - estadounidense en concreto pero que podría trasladarse a otras economías incluida la nuestra-se puede corregir "dentro" de la misma economía de mercado; prosigue planteándose cuáles serían las "metas" a alcanzar en la economía norteamericana: las podríamos sintetizar en una: en la denominada "igualdad de oportunidades"; pero, existe un cáncer en la economía que se opone a esa igualdad de oportunidades, dice Stiglitz que es el exceso de las "rentas" en manos de unos pocos así como una ideología política que prohija esa mala concentración de la riqueza económica; y ante ese cáncer... ¿cuál sería el remedio?: dice que moderar los excesos dentro de una reglas jurídicas concretas.

Entrando en "detalles" más concretos, Stiglitz habla de una "serie de reformas o correctivos" -también "dentro" del capitalismo como lo hizo Cortina según ya vimos antes-, que paso a resumir:

- Poner coto a los excesos en la parte alta. Esto significa poner coto al sector financiero, el cual incluye: poner coto al endeudamiento de la gente (que seguramente conduce al consumismo exagerado y riesgoso); propiciar la transparencia en los bancos; que las tarjetas de crédito no abusen con los intereses; poner coto a las bonificaciones, que llevan a su vez a riesgos exagerados; y la prohibición de los "paraísos fiscales", que no son más que burlas descaradas a las normas jurídicas.

- Las leyes de la competencia deben ser muy estrictas, de manera que haya más competencia de los productos y se combatan los monopolios.

- Limitar el poder económico de los altos directivos y abrir la posibilidad de que otras remuneraciones en la misma empresa no sean tan distantes de las de esos altos directivos o "gurús" de la empresa. 
- Evitar que los gobiernos privilegien a las empresas grandes con exenciones, dádivas, subvenciones, créditos baratos para ellas, avales fáciles a esos créditos, y estableciendo mayores responsabilidades a ellas (por ejemplo en materia de medio ambiente).

- Propiciar el acceso a la justicia de todas las personas que lo requieran.

- Reducir la carrera armamentista.

- Hacer una reforma fiscal. Ella implica impuestos progresivos, erradicar los vacíos legales, crear más empleos, propiciar mayor inversión pública para crecer económicamente, y gravar las sucesiones y plusvalías del capital.

- Ayudar a los demás. En este acápite habla de cuatro puntos concretos: a) mejorar el acceso a la educación (que es la herramienta que más propicia la igualdad de oportunidades); b) ayudar a la gente a ahorrar; c) mejorar los índice de salud (y dentro de este punto pide que los farmaceutas y aseguradores en salud ganen menos); d) y mejorar el seguro de desempleo, la seguridad social, los cupones de alimentos, y todo lo que ayude a una mayor protección social de la gente con menores recursos.

- Suavizar la globalización. Se queja Stiglitz de los TLCs asimétricos, que llevan a su vez a los proteccionismos económicos de los países [en nuestro caso colombiano, a raíz del primer año del TLC con E.U., hemos visto las noticias de cómo el "rico" E.U. se benefició 4 veces más que la "pobre" Colombia: ¿ello no suscita enormes interrogantes? (cfr. El Tiempo, 13 de mayo de 2013; desde luego somos conscientes de que las estadísticas y los números ameritan mayores análisis, y así, por ejemplo, sabemos que las importaciones no son malas per se por ser mayores que las exportaciones, en un momento dado, pues importar más puede ser para mejorar después las exportaciones)].

Dentro de esta medida menciona la necesidad de combatir los dineros calientes con normas estrictas.

- Buscar el "pleno empleo" como política principal del gobierno (volvemos a insistir en que el análisis de Stiglitz es para E.U. pero puede servir perfectamente para el caso colombiano).

- Buscar el equilibrio comercial [el punto medio como venimos diciendo en nuestro lenguaje filosófico; Raúl Prebisch decía hace casi tres décadas que uno de los secretos de la economía era alcanzar el 
equilibrio en la balanza de pagos, un equilibrio entre las importaciones y las exportaciones, alterado por obra del exceso de importaciones por el deseo de imitar a las altas sociedades de consumo (2013, abril 21)].

Recuerda aquí Stiglitz que exportar genera empleo e importar lo mata.

- Valorar más a los trabajadores frente al capital, lo que nuestro autor llama crear un "nuevo pacto social".

- No seguir discriminando racialmente y por cuestiones de género.

- Reorientar la inversión y la innovación para conservar los puestos de trabajo y el medio ambiente: no quitar empleos para ahorrar recursos económicos.

- Crecer económicamente (aumentar el PIB) pero con "calidad" de ese crecimiento, es decir, propiciando el crecimiento humano.

- Aumentar y mejorar en vivienda (en Colombia acabamos en buena hora con el UPAC y lo reemplazamos por la UVR, pero seguimos en deuda con el alto precio de la vivienda nueva y usada; igualmente hemos mejorado con el programa de dar 100.000 casas a la gente más pobre).

- Todas las reformas anteriores requieren, dice Stiglitz, de una política, como por ejemplo la que reforme la financiación a las campañas electorales por parte de las grandes empresas.

Termina Stiglitz con un clamor ético de todos los tiempos: que el bienestar común esté por encima del interés particular. Eso es justicia económica a nuestro juicio.

Como puede verse al concluir esta reseña de autores, en los tres existe un núcleo común: lo justo en economía es que ella esté abierta a la libertad en lo económico, pero libertad que debe ser regulada por el derecho; es, pues, una libertad económica "compleja", esto es, aliada con el derecho y la política. Es el famoso trípode del que venimos hablando desde el principio.

Dicho lo anterior cabría preguntarse, no obstante, si el capitalismo es, en efecto, como dice Adela Cortina, un sistema lícito per se, sólo que enmarcado en parámetros reguladores y transformadores, o, por el contrario, ello no es posible pues se lo considera malo en sí mismo -lacra de la humanidad según algunos-, siendo su alternativa otro tipo de sistema económico, por ejemplo el socialismo económico, o el "socialismo del siglo XXI" como también se le ha llamado en Latinoamérica.

Estaríamos de esa manera ante dos sistemas en competencia, como en realidad, lo están. 
Es una pugna que trasciende lo puramente económico y llega también a lo político, alinderándose el mundo en dos modelos en evidente contraste.

Es una lucha que vemos feroz, donde se observa un mundo claramente dividido y enfrentado; así, el mundo capitalista sigue privilegiando la libertad económica individual aunque regulada fuertemente por el derecho y el Estado, y el mundo socialista con la mayor acción y presencia del Estado, reduciendo la libre iniciativa económica individual. Esas son las alternativas económico-políticas de hoy en día, sobre todo para Latinoamérica, que, desde luego deseamos que no lleven a una especie de "guerra mundial" entre esos dos bloques (como pareciera avizorase por momentos en los casos de los bloques de Corea del Norte-Venezuela, Irán, China, Cuba..., versus el bloque occidental estadounidense-europeo). Civilizadamente debemos esperar los respectivos frutos para tomar experiencias al futuro.

En efecto, el mundo capitalista está enfrentando, una vez más, una de esas crisis periódicas que suele padecer, pero también en él se formulan unas propuestas desde dentro de él mismo y que es menester esperar en esta ocasión a ver cómo se implementan dichos correctivos y cuáles serían sus resultados (caso de Estados Unidos y Europa; a este respecto las propuestas de J. Stiglitz para reformar la economía de los EE.UU.); pero el mundo socialista también está en una situación similar en el sentido de que es un modelo joven cuyos resultados están por verse, pues en unos países se han dado resultados positivos en los campos sociales, económicos y políticos (vgr. Brasil, Ecuador, Chile), y en otros no (Venezuela, Argentina, por ejemplo), por lo que es prematuro saber concluyentemente si es un modelo -el socialista- viable pues las variables son muchas.

Por eso consideramos que es preferible un margen de espera tanto de uno como de otro modelo socio-económico-político mientras se van viendo los resultados.

Lo que sí parece más cierto es que más allá del modelo en sí mismo considerado -sobre todo el económico-, éste depende, como todas las cosas (teorías, modelos, regímenes...) de los hombres concretos, de su actuación... de su ética personal en últimas. Con ello no queremos decir que el modelo o la estructura no importen, pero dicho modelo por sí no subsiste ni da resultados sin hombres concretos de carne y hueso; es lo que Amartya Sen llama los comportamientos reales de las personas; consideramos que en última instancia las cosas dependen más de la actitud ética de las personas que de las estructuras (recuerdo a un amigo que fue miembro de la Asamblea Nacional Constituyente de 1991 a quien en una ocasión lo encontré alicaído, 
y al yo preguntarle qué le pasaba, me contestó que él había creído que con estructuras políticas nuevas el país cambiaría, pero no, que encontraba que el problema central del país era el "corazón" dañado de la gente; es lo que pretendo decir también ahora: el asunto central de la política, del derecho, de la economía es la actitud ética de las personas concretas). 



\section{Y... ¿QUÉ ES EL DERECHO?}

"Si la filosofía del derecho se ocupa de las razones últimas del derecho, de sus principios supremos, sus temas fundamentales son, en nuestra opinión los siguientes: a) El concepto de derecho, o sea, la respuesta a la pregunta ¿quid ius?, muy distinta de la que se hace la ciencia jurídica ¿quid iuris?..."

(Rodrigo Noguera Laborde)

Llegamos al final pues tenemos elementos suficientes para poder plantearnos la pregunta típica de la filosofía del derecho: quis ius

Terminan estas reflexiones con dicha pregunta (aunque ya hemos dicho que nos adscribimos no sólo a esta postura fundamentadora del derecho sino también a la postura existencial del mismo); no es tarea fácil pues el derecho, aunque es en el fondo uno solo-el derecho, no los derechos-, tiene varias facetas. Pero, llegados a este punto de nuestro trabajo, vale la pena plantearnos esta pregunta y tratar de afrontarla.

Precisamente Robert Alexi, autoridad de hoy en la materia, habla del "doble carácter" del derecho: "Si el derecho necesariamente se conecta con una pretensión de corrección, el derecho consiste en algo más que en la pura facticidad del poder, órdenes respaldadas por amenazas, hábito, o coerción organizada. Su naturaleza no sólo comprende un lado fáctico o real, sino también una dimensión crítica o ideal” (Alexi, Buligyn, 2001, p. 95).

Para Alexi entonces, el derecho tiene dos caras: la suprapositiva-moralideal, y la positiva-normativa-coercitiva-organizada.

Con otro lenguaje aunque próximo al de Alexi, en la antigüedad Aristóteles había dicho: "De lo justo político una parte es natural, otra legal. Natural es lo que en todas partes tiene la misma fuerza y no depende de nuestra aprobación o desaprobación. Legal es lo que en un principio es indiferente que sea de este modo o del otro, pero que una vez constituidas las leyes deja de ser indiferente" (Aristóteles, 1981, p. 66).

Para Aristóteles, también como Alexi, el derecho tiene dos caras: la natural y la legal. ¿No hay acaso una cierta simetría entre el derecho natural 
aristotélico y el derecho crítico alexiano, entre el derecho legal y el derecho fáctico, de los dos autores mencionados?

$\mathrm{Y}$ en el medio de esos tiempos que separan a Aristóteles (siglo IV a. de C.) de Alexi (s. XX), podemos echar mano de otro filósofo que también vio las varias facetas del derecho, aunque con un cariz distinto a los anteriores: Thomasius (1655-1728), para quien existe el derecho natural, sin coacción, siendo así ley impropia y sí un consejo como de tipo moral, y la ley positiva, con coacción (Beuchot, 2006, pp. 66-67).

Para Thomasius pues, hay un derecho natural no coactivo y un derecho legal coactivo.

Con lo anterior se quiere poner de presente con una pequeña muestra de autores, la dificultad de englobar el derecho en una sola idea pues éste tiene como se ve al menos dos caras.

Atrevámonos entonces ya a dar una idea del derecho (en general, desde luego, como corresponde a la iusfilosofía):

Es un orden normativo social, enraizado en la naturaleza del hombre y del universo físico -y por eso perenne-, pero, al mismo tiempo -y ello requiere de acomodaciones normativas- dinámico a las circunstancias sociales históricas, que por ser procedente del hombre como unidad es a la vez interno y externo (esto es, social), con carácter coactivo y sancionatorio por parte de la autoridad que lo profiere y establece, con el fin de ir en pos de la justicia.

Intentemos ahora explicar esas afirmaciones:

a. Es un orden normativo social: orden, estructura, mediante preceptos, reglas, leyes, para la vida en comunidad; sabemos que existen diversos órdenes normativos: religiosos, morales, científicos..., pero el derecho es un tipo de orden mediante leyes que se caracterizan por ser para la polis.

b. Consideramos que la fuente primaria del derecho es la naturaleza del hombre y el mundo de la physis: ello garantiza que el derecho no se convierta sólo en ideología, sino que al estar enraizado en el hombre y en el cosmos, garantiza que el derecho sea también corpología, no mera ideología al vaivén de los gobernantes de turno. Esa atadura a lo corporal y cósmico, no inventado sino descubierto o transformado ética y legalmente, lo hace más estable, seguro, garante y perenne.

c. Ahora bien, sabemos que el hombre y la sociedad son evolutivos, históricos, y por ello cada tiempo tiene sus circunstancias que obligan 
a que el derecho busque la justicia como tarea práctica, permanente, aquí y ahora.

d. Como el derecho está enraizado en el hombre, a fin de no hacer al ser humano un ser ezquizofrénico, con doble vida, el derecho, aunque tiene un más grande componente social que meramente individual, no quita la interioridad del hombre; el hombre es un ser sólo y al mismo tiempo social; así, el hombre debería cumplir con el derecho por convicción, por razones íntimas de conciencia y por lo que implica el salvaguardar a la comunidad en la que vive; considerar al derecho como una entidad puramente exterior, como se ha querido hacer ver tradicionalmente, es hacer al hombre un ser con doble faz, esquizoide.

e. El derecho es tanto regulador como sancionador; existen normas sin sanción; existen normas puramente reguladoras (piénsese por ejemplo en la parte organizativa de la Constitución Política de un Estado) -que, por cierto se cumplen regularmente de manera reiterativa, común, estable, pacífica (piénsese por ejemplo en el día a día de tantas instancias que cumplen el derecho permanentemente)-, y un derecho con sanciones exteriores (cárceles...).

f. El fin del derecho es la justicia: la justicia conmutativa o entre particulares, y distributiva o del Estado, o de toda autoridad superior, para con sus miembros.

Lo anterior podría resumirse aún más de la siguiente manera:

El derecho es un mandato (precepto, regla, ley, norma, llámese como se llame ya que a la filosofía del derecho no le corresponde especificar estos términos, tarea que le corresponde a la Teoría jurídica), humano (esto es, un mandato hecho "desde el hombre", es decir, hecho positivamente por el legislador, y "para los hombres", esto es, para la comunidad humana), obedecido (con una cierta coactividad), ó, desobedecido (y por tanto sancionable), cuyo fin es la justicia.

Expresemos lo dicho antes de manera corrida: el derecho es un mandato humano obedecido ó desobedecido y por tanto sancionable en razón de la justicia.

De otra parte no resistimos el deseo de agregar a lo anterior que un camino quizá más expedito para entender qué es el derecho es mirarlo como lo hace la tercera vía iusfilosófica, esto es, mirarlo como qué NO ES derecho: es lo evidentemente injusto, lo palmariamente injusto, lo notoriamente injusto; si 
se lo mira de esta manera creemos que se entiende para cualquier espíritu de modo más fácil.

Teniendo ante los ojos lo evidentemente injusto es más propicio luchar por el derecho; en efecto, por ejemplo en nuestro medio es muy notoria la injusticia del hacinamiento en las cárceles; pero debido a que los presos no dan votos, $\mathrm{y}$, como en el inconsciente colectivo todos pensamos que bien presos deben estar los presos, pues nada o casi nada se hace por ellos; es eso una injustica flagrante ante la cual deberíamos oponernos con cierta facilidad.

Por ello, y ya para concluir este punto, ciertamente no solo debemos saber lo que es el derecho de manera teórica -lo primero que hemos intentado en este acápite-, sino tener la sensibilidad ética para percibir lo claramente injusto, y es más, proceder con acciones concretas para proteger el derecho: desde las instituciones pasando por las personas con sus acciones y comportamientos reales; de nada sirve saber qué es el derecho si no se le protege efectivamente; debemos pasar de lo sabido teóricamente a la protección del derecho efectivamente. 


\section{CONCLUSIÓN}

Puede que lo que veamos en el mundo no sea el punto medio equilibrado, pero el punto medio, implícita o explícitamente, es lo que muchas veces deseamos ver hecho realidad, y, si lo deseamos, las cosas del entorno deberían ser de otra manera a como aparecen; así resulta suceder y debería ser en el derecho también, tan atropellado tantas veces por intereses de poder (economicista, político, individualista).

Es una tarea difícil, pero solo lo arduo merece la pena ser luchado.

¿Cómo lograr ese punto medio? Aquí sólo hemos planteado ciertas rutas. Se trata de meditarlas junto con otras posibles y después tratar de vivirlas, si es que en realidad de verdad existe una convicción por ello. 



\section{BIBLIOGRAFÍA}

Albendea, J. (1994). El preámbulo de la Constitución colombiana, Bogotá, Colombia: Dikaion, Universidad de La Sabana.

Alexi, R. (2011). Ámbito Jurídico, 17-30 de octubre, Bogotá, Colombia.

- (2005). La pretensión de corrección del derecho, Bogotá, Colombia: Universidad Externado de Colombia.

Aristóteles. (1981). Ética a Nicómaco, México: Editorial Porrúa.

Benedicto XVI (2005). Deus caritas est.

—. (2011). Discurso al Bundestag,

Beuchot, M. (2006). Filosofia del derecho, hermenéutica y analogía, Bogotá, Colombia: Universidad santo Tomás.

Boff, L.(1996). Ecologia: grito de la tierra, grito de los pobres, Madrid, España: Trotta.

—. La opción tierra (2008). Sal terrae, Santander, España.

Carpio, J. (1999). De igual a igual, El desafio del Estado ante los nuevos problemas sociales.

Carrasquilla, F. (2000). Escuchemos a los pobres, Quito, Ecuador: Editorial Tierra Nueva.

Concilio Vaticano II, Gaudium et spes.

Cortina, A. (2000). Ética de la empresa, Madrid, España: Editorial Trotta.

- (2010). Las raices éticas de la democracia, España: Universidad de Valencia.

D’Agostino (2007). Filosofía del derecho, Bogotá, Colombia: Temis-Universidad de La Sabana.

D’Ors, A. (1973). Escritos varios sobre el derecho en crisis, Consejo Superior de investigaciones científicas-Delegación de Roma, Roma, Madrid.

De Aquino, T. (1975). Tratado de la justicia, México: Editorial Porrúa.

—. Tratado sobre la justicia, México: Editorial Porrúa, 1998.

Di Castro, E. \& Dieterlen, P. (2005). Debates sobre justicia distributiva, Universidad Nacional Autónoma de México. 
Fals, O. (2008). El socialismo raizal y otros escritos, Biblioteca Vértices colombianos, Bogotá, Colombia: Cepa, Ediciones desde abajo.

- (2008). La subversión en Colombia, Fica Cepa, Bogotá, Colombia.

Foucault, M. (2004). Poder vs Democracia, Bogotá, Colombia: Fica.

García, M. (1952). Lecciones preliminares de filosofia, México: Editorial Diana.

Gargarella, R. (1999). Derecho y desventajados, Barcelona: Gedisa Editorial.

Goñi, C. (2003). Qué es eso de la filosofía, Madrid, España: Palabra.

Gorbachov, M. (1988). Perestroika, Bogotá, Colombia: Editorial Oveja Negra.

Hobbes, T. (2007). Leviatán, Buenos Aires, Argentina: Losada.

Juan Pablo II (1991). Centesimus annus.

Kaufmann, A. (1999). Filosofía del derecho, Bogotá: Universidad Externado de Colombia.

Kaufmann, A. (1998). La filosofía del derecho en la posmodernidad, Bogotá, Colombia: Temis.

Kelsen, H. (2005). ¿Qué es la justicia?, Biblioteca de ética, filosofía del derecho y política, $17^{\mathrm{a}}$ reimpresión, Bogotá, Colombia.

—. (2000). Teoría pura del derecho, Santa Fe de Bogotá, Colombia: Editorial Unión limitada.

Küng, Hans, Kuschel, K.-J. (1994). Hacia una ética mundial, Madrid: Editorial Trotta, España.

Locke, J. (2006). Segundo tratado sobre el gobierno civil, Madrid, España: Tecnos.

Mejía, O. \& Encinales, N. (2011). Elementos para una historia de la filosofia del derecho en Colombia, Bogotá, Colombia: Ibáñez.

Morin, E. (2001). Los siete saberes necesarios para la educación del futuro, Bogotá, Colombia: Magisterio.

Mounier, E. (2002). El personalismo, Bogotá, Colombia: Editorial Nueva América.

Noguera, R. (1997). Elementos de filosofía del derecho, Bogotá, Colombia: Universidad Sergio Arboleda.

Noguera, R. (2002). Introducción general al derecho, Universidad Sergio Arboleda, Bogotá, Colombia.

Ortega \& Gasset, J. (2007). ¿Qué es filosofía?, Madrid, España: Austral.

—. (2010). El tema de nuestro tiempo, Madrid, España: Austral.

Ratzinger, J. (2005). Verdad, valores, poder, Madrid, España: Rialp.

Rousseau, J. J. (2009). El contrato social, Bogotá, Colombia: Panamericana Editorial. 
Sábato, E. (2000). Hombres y engranajes, Madrid, España: Alianza Editorial.

Sancho, I., M. \& Hervada, J. (1980). Compendio de derecho natural, tomos I y II, Pamplona, España: EUNSA.

Sandel, M. (2011). Justicia, Bogotá, Colombia: Debate.

Sartori, G. (1994). ¿Qué es la democracia?, Bogotá, Colombia: Altamir,

Sen, A. (2010). La idea de la justicia, Bogotá, Colombia: Taurus.

Smith, P. (2009). La democracia en América Latina, España: Universidad de Alcalá.

Stiglitz, J. (2012). El precio de la desigualdad, Bogotá, Colombia: Taurus.

Touchard, J. (1961). Historia de las ideas políticas, Tecnos, Madrid, España.

Zabalza, J. (1991). El derecho objetivo del 25\%, Bogotá, Colombia: Universidad Santo Tomás.

Zagrebelsky, G. (2005). El derecho dúctil, Torino, Italia: Editorial Trotta. 
Esta obra se terminó

de imprimir en junio de 2016

con un tiraje de 500 ejemplares

en los Talleres Gráficos de

Grupo Editorial IBÁÑEZ

Carrera 69 Bis No. 36-20 Sur.

Tels: 2300731 - 2386035

Bogotá D.C. - Colombia 
